OECD Corporate Governance Working Papers No. 14

State-Invested Enterprises in the Global Marketplace: Implications for a Level Hans Christiansen, Playing Field 


\section{OECD CORPORATE GOVERNANCE WORKING PAPERS}

OECD Working Papers should not be reported as representing the official views of the OECD or of its member countries. The opinions expressed and arguments employed are those of the authors.

Working Papers describe preliminary results or research in progress by the author(s) and are published to stimulate discussion on a broad range of issues on which the OECD works. Comments on Working Papers are welcomed, and may be sent to either corporate.affairs@oecd.org or the Corporate Affairs Division, OECD, 2 rue André-Pascal, 75775 Paris Cedex 16, France.

The papers are generally available only in their original language, English or French, with a summary in the other if available.

Comment on the series is welcome, and should be sent to either corporate.affairs@oecd.org or the Corporate Affairs Division, OECD, 2, rue André Pascal, 75775 PARIS CEDEX 16, France.

\section{OECD CORPORATE GOVERNANCE WORKING PAPERS \\ are published on www.oecd.org/daf/corporateaffairs/wp}

This document and any map included herein are without prejudice to the status of or sovereignty over any territory, to the delimitation of international frontiers and boundaries and to the name of any territory, city or area.

The statistical data for Israel are supplied by and under the responsibility of the relevant Israeli authorities. The use of such data by the OECD is without prejudice to the status of the Golan Heights, East Jerusalem and Israeli settlements in the West Bank under the terms of international law.

Note by Turkey:

The information in this document with reference to "Cyprus" relates to the southern part of the Island. There is no single authority representing both Turkish and Greek Cypriot people on the Island. Turkey recognises the Turkish Republic of Northern Cyprus (TRNC). Until a lasting and equitable solution is found within the context of the United Nations, Turkey shall preserve its position concerning the "Cyprus issue”.

Note by all the European Union Member States of the OECD and the European Union:

The Republic of Cyprus is recognised by all members of the United Nations with the exception of Turkey. The information in this document relates to the area under the effective control of the Government of the Republic of Cyprus.

(C) OECD 2014

Applications for permission to reproduce or translate all or part of this material should be made to: OECD Publishing, rights@oecd.org or by fax 33145249930. 


\title{
State-Invested Enterprises in the Global Marketplace: Implications for a Level Playing Field
}

\author{
By Hans Christiansen and Yunhee Kim*
}

Approved by Adrian Blundell-Wignall, Director, OECD Directorate for Financial and Enterprise Affairs

\begin{abstract}
State-owned and other state-invested enterprises (SIEs) have become more prominent in the global economy over the last decade. A growing role for state-invested enterprises in the marketplace is not in itself onerous. According to an OECD consensus, as expressed through the Organisation's legal instruments, SOEs can be operated according to similarly high standards of governance, transparency and efficiency as private companies, in which case the ownership issue is moot. However, only some of the world's most advanced economies, following decades of reform of their SOE sectors, have approached this point. Moreover, when SOEs operate across borders the challenges may multiply. With this background, this paper compares the difference between SIEs and non- SIEs in five sectors: air transportation, electricity, mining, oil \& gas and telecommunication. The empirical analysis indicates that, in addition to any financing advantages, large state-invested enterprises also seem to benefit from an unusually favourable position in their home markets. A comparative analysis further shows that, in the course of the last ten years, SIEs have generally enjoyed higher rates of return than comparable private companies. The paper concludes that the growing role of state-invested enterprises in the international marketplace does not yet present a serious macroeconomic challenge. However, since it is likely to keep growing for some time, challenges need to be addressed relatively soon. This makes for a strong case for enhanced policy coordination and information sharing. If legally binding instruments cannot be developed in the near to medium-term to ensure competitive neutrality, consultation mechanisms could be established through which the main players in international trade and investment can exchange views on matters of common concern related to the state in the marketplace. The ultimate purpose would be ensuring that the international trade and investment environment remains open, non-discriminatory and offering a level playing field.
\end{abstract}

JEL Classification: F21, F23, G30, G38, L32, L33

Keywords: competition, competitive neutrality, international investment, multinational firms, stateowned enterprises

* Hans Christiansen is Senior Economist and Yunhee Kim is Economist in the OECD Directorate for Financial and Enterprise Affairs, Corporate Affair Division. Earlier versions of the paper have been approved as work in progress by the OECD Working Party on State Ownership and Privatisation Practices as well as reviewed by delegates of the OECD Competition Committee and participants in a Seminar on New Approaches to Economic Challenges (NAEC). Colleagues in the OECD secretariat provided useful comments. 


\section{TABLE OF CONTENTS}

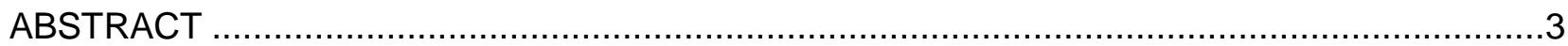

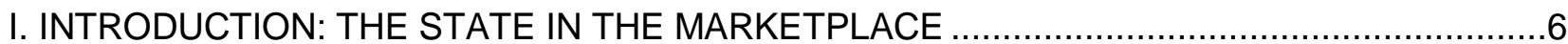

II. PUBLIC-PRIVATE COMPETITION: CONCERNS AND CHALLENGES ..............................11

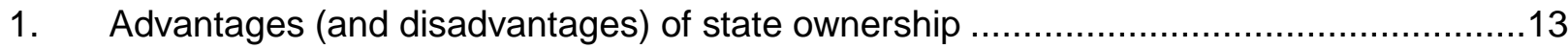

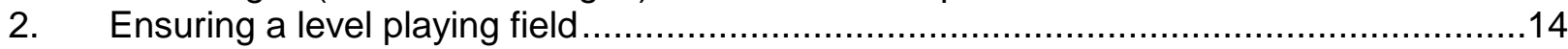

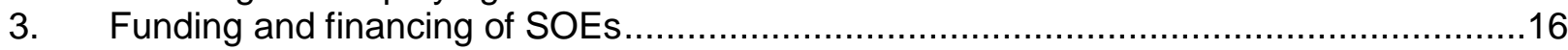

III. PERFORMANCE AND FINANCING OF THE WORLD'S LARGEST SOES .......................18

1. The Forbes $($ C) Global 2000 and the OECD corporate database ...............................18

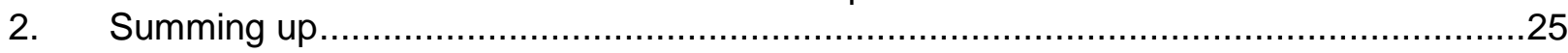

IV. INTERNATIONAL INVESTMENTS BY STATE-OWNED AND OTHER ENTERPRISES .......26

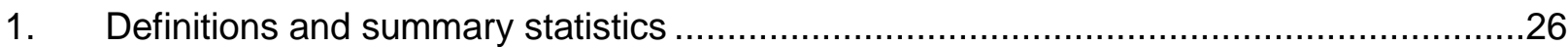

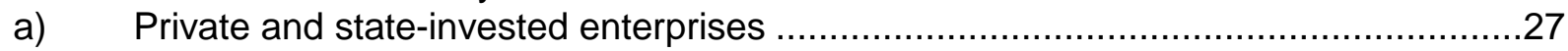

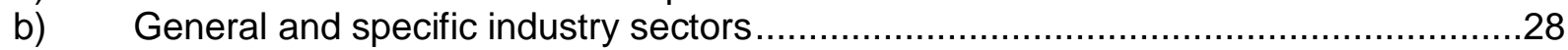

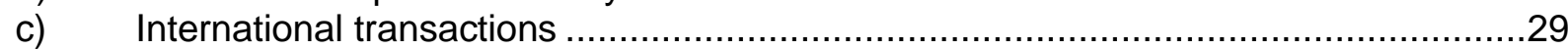

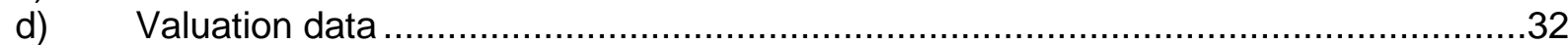

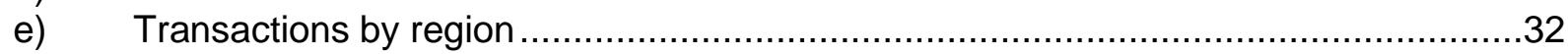

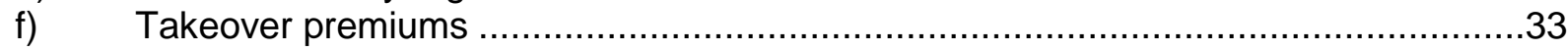

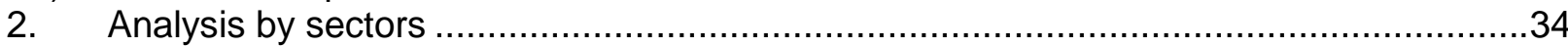

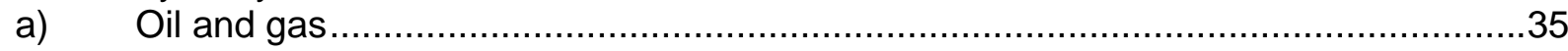

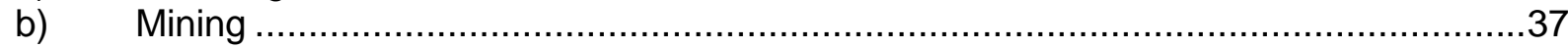

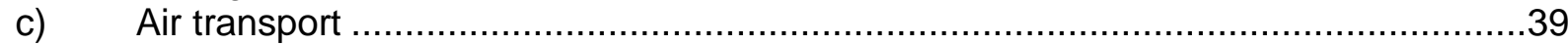

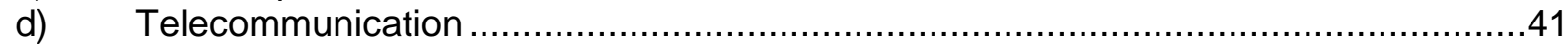

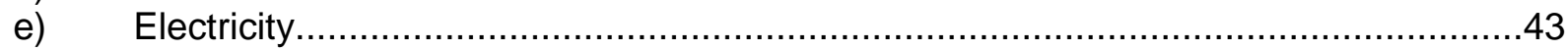

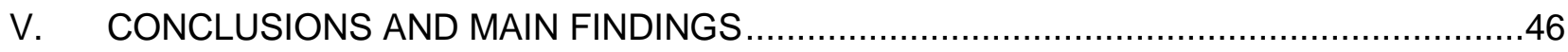

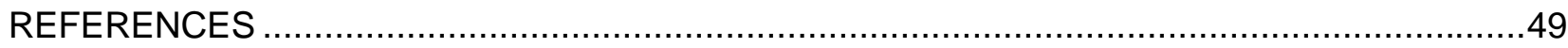

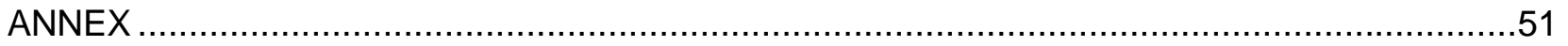




\section{Tables}

Table 1. The world's largest 25 SOEs in the business year 2012-13 (US\$ billion) ................7

Table 2. The world's largest 25 PSOEs in the business year 2012-13 (US\$ billion) ..............8

Table 3. Distribution of companies by five sectors and SIEs indicators ..........................18

Table 4. Comparison of PCM and other margin indicators by sector from 2000 to $2010 \ldots \ldots 24$

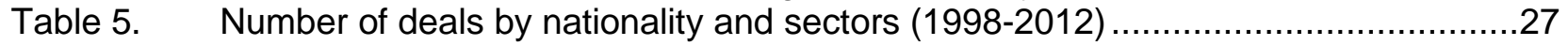

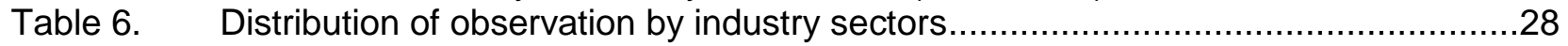

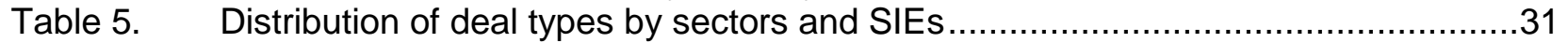

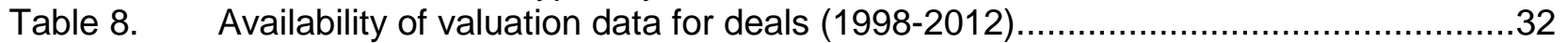

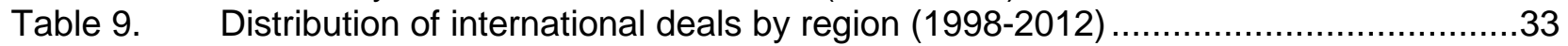

Table 10. Top-5 international M\&As undertaken by SIEs in the oil and gas sector

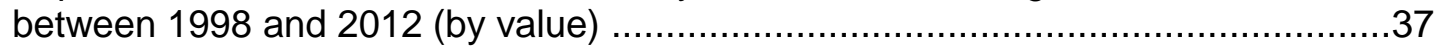

Table 11. Top-5 international M\&As undertaken by SIEs in the mining sector between 1998 and 2012 (by value) .................................................................38

Table 12. Top-5 international M\&As undertaken by SIEs in the air transport sector between 1998 and 2012 (by value) .............................................................41

Table 13. Top-5 international M\&As undertaken by SIEs in the telecom sector between 1998 and 2012 (by value) .............................................................43

Table 14. Top-5 international M\&As undertaken by SIEs in the power generation sector

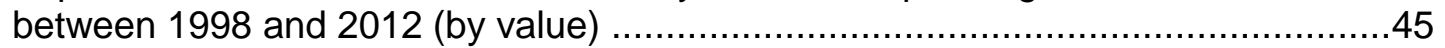

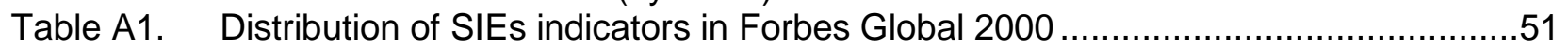

Table A2. The descriptive statistics information ...................................................... 64

Table A3. Nationality of acquirer in all deals and distribution of SIEs in the five sectors

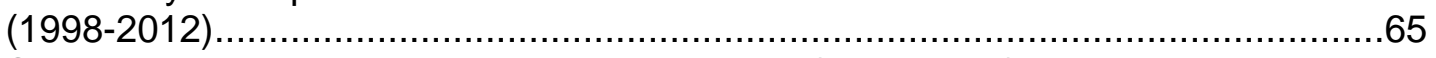

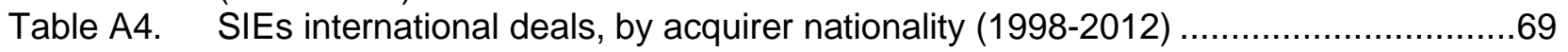

\section{Figures}

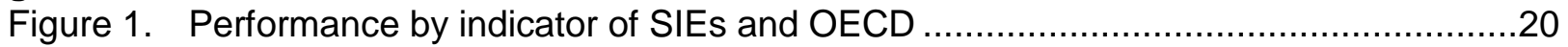

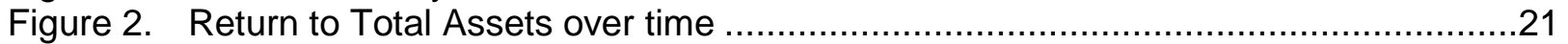

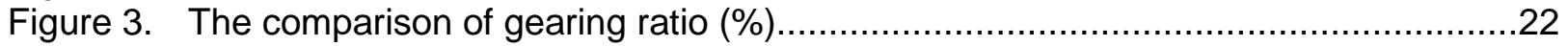

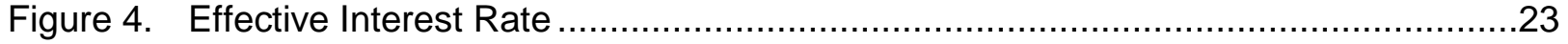

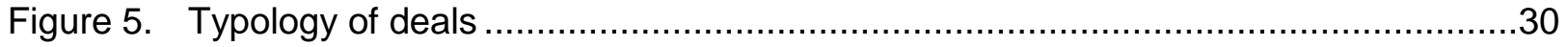

Figure 6. Distribution of cross-border and non-cross-border deals by SIEs (1998-2012) .......31

Figure 7. Premium in international takeovers by ownership and sector ...........................34

Figure 8. Share of international M\&As with a state-invested acquirer ...............................35

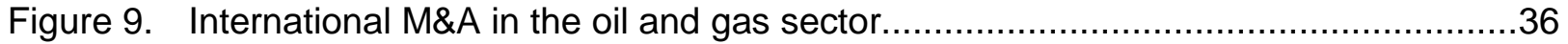

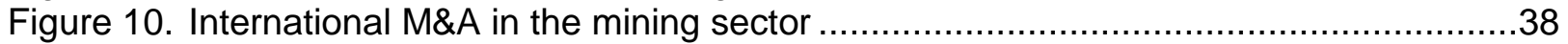

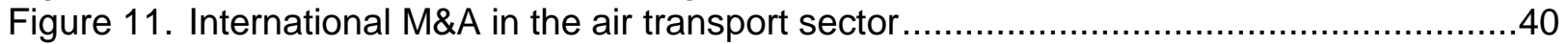

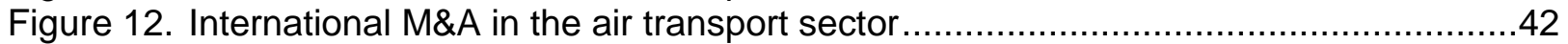

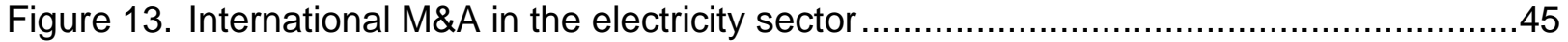

\section{Boxes}

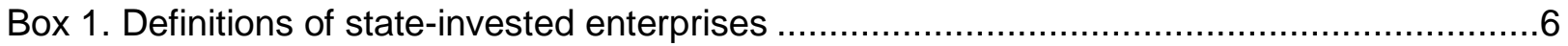

Box 2. The expanding presence of Yanzhou Coal in the Australian mining sector ..................39

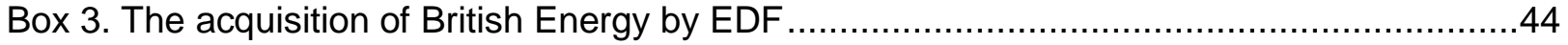




\section{INTRODUCTION: THE STATE IN THE MARKETPLACE}

The presence of state-owned or state-invested enterprises in the global corporate landscape is greater than what is commonly assumed. What is more, it has increased over the last decade: earlier research by the OECD Secretariat indicated that the presence of state-owned enterprises (SOEs) in the world's top-50 and top-100 enterprises has grown significantly in the course of the last decade - mostly reflecting the fact that Chinese companies have risen in the rank tables. To create some more clarity over the methodologies applied to State participation in the corporate sector some definitions are proposed in Box 1.

\section{Box 1. Definitions of state-invested enterprises}

For the purpose of this paper the word state-invested enterprise (SIE) denotes a corporation in which the State is the ultimate beneficiary owner, on a consolidated basis, of at least $10 \%$ of the voting stock (or equivalent, if the corporation is not a joint stock company) ${ }^{1}$.

By "State" is meant the central level of government, except for federal nations where sub-national levels of government in whom sovereignty is vested (insofar as the relevant information is available) are also included. There are two categories of SIEs:

- $\quad$ State-owned enterprises (SOES). This category includes: (1) corporate entities entirely owned by the State; (2) joint stock companies or partnerships in which the State (on a consolidated basis) owns more than $50 \%$ of the voting rights; and (3) corporate entities in which the State has a degree of control that is equivalent to majority ownership.

- $\quad$ Partially state-owned enterprises (PSOES). Corporate entities where the state controls at least $10 \%$ but less than $50 \%$ of the voting stock (or has an equivalent degree of control).

An illustration of the importance of SOEs in the global corporate landscape is provided on Table 1. The table is based on the latest available version of Forbes Global 2000, which ranks companies according to an average of their valuation, sales, profit and asset value. It appears from the table that eleven of the world's largest 50 corporations are state-owned. The nationality distribution is distinctly skewed: among the world's largest 25 SOEs, 13 are domiciled in China (including Hong Kong, China), 3 are Russian, 2 are Brazilian and 3 are domiciled within OECD countries. Moreover, according to the ranking methodology applied by Forbes, the world's two largest corporations in 2013 (ICBC and China Construction Bank) were both Chinese and both located in the banking sector.

\footnotetext{
${ }^{1}$ For a further discussion of methodology, see Christiansen and Kane (2013).
} 
Table 1. The world's largest 25 SOEs in the business year 2012-13 (US\$ billion)

\begin{tabular}{|c|c|c|c|c|c|c|}
\hline $\begin{array}{c}\text { Global } \\
\text { rank }\end{array}$ & Company & Sector & Domicile & $\begin{array}{c}\text { Market } \\
\text { value }\end{array}$ & Sales & Assets \\
\hline 1 & ICBC & Banking & China & 237.3 & 134.8 & 2813.5 \\
\hline 2 & China Construction Bank & Banking & China & 202.0 & 113.1 & 2241.0 \\
\hline 8 & Agricultural Bank of China & Banking & China & 150.8 & 103.0 & 2124.2 \\
\hline 10 & PetroChina & Oil \& Gas & China & 261.2 & 308.9 & 347.8 \\
\hline 11 & Bank of China & Banking & China & 131.7 & 98.1 & 2033.8 \\
\hline 17 & Gazprom & Oil \& Gas & Russia & 111.4 & 144.0 & 339.3 \\
\hline 20 & Petrobras & Oil \& Gas & Brazil & 120.7 & 144.1 & 331.6 \\
\hline 26 & Sinopec-China Petroleum & Oil \& Gas & China & 106.9 & 411.7 & 200.0 \\
\hline 29 & China Mobile & Telecom & $\begin{array}{c}\text { Hong Kong, } \\
\text { China }\end{array}$ & 213.8 & 88.8 & 168.7 \\
\hline 30 & $\mathrm{ENI}^{2}$ & Oil \& Gas & Italy & 86.3 & 163.7 & 185.2 \\
\hline 38 & Statoil & Oil \& Gas & Norway & 78.1 & 126.8 & 140.2 \\
\hline 59 & Rosneft & Oil \& Gas & Russia & 73.2 & 68.8 & 126.3 \\
\hline 61 & Sberbank & Banking & Russia & 73.3 & 36.1 & 441.1 \\
\hline 67 & Banco do Brasil & Banking & Brazil & 37.9 & 69.0 & 552.2 \\
\hline 74 & EDF & Electricity & France & 35.3 & 95.9 & 325.2 \\
\hline 94 & Saudi Basic Industries & Chemicals & Saudi Arabia & 74.8 & 50.4 & 90.2 \\
\hline 106 & China Life Insurance & Insurance & China & 79.9 & 63.2 & 304.6 \\
\hline 111 & CNOOC & Oil \& Gas & $\begin{array}{c}\text { Hong Kong, } \\
\text { China }\end{array}$ & 84.3 & 39.2 & 73.2 \\
\hline 114 & Ecopetrol & Oil \& Gas & Colombia & 116.2 & 39.0 & 64.4 \\
\hline 115 & China Shenhua Energy & $\begin{array}{c}\text { Metals \& } \\
\text { Mining }\end{array}$ & China & 70.8 & 39.7 & 70.2 \\
\hline 128 & China Citic Bank & Banking & China & 32.5 & 24.4 & 474.7 \\
\hline 136 & State Bank of India & Banking & India & 28.1 & 35.1 & 359.1 \\
\hline 139 & China Telecom & Telecom & China & 42.0 & 44.9 & 87.4 \\
\hline 143 & Industrial Bank & Banking & China & 38.2 & 18.7 & 382.3 \\
\hline 144 & PTT & Oil \& Gas & Thailand & 32.9 & 89.9 & 53.3 \\
\hline
\end{tabular}

The previous findings might lead some to the conclusion that state control over commercial enterprises is a phenomenon largely confined to emerging economies - notably China. However, if the shares in, for instance, a listed company are widely held then a major investor need to hold significantly less than $50 \%$ of the voting shares in order to effectively control that company. For the purpose of this paper it is assumed (in keeping with a methodology also applied in international investment statistics) that investors do not hold more than $10 \%$ of the shares in a company unless they have strategic intent. This is the basis for the definition of partly stateowned enterprises proposed in Box 1. Table 2 provides an overview of the world's largest (again according to Forbes 2000 methodology) 25 PSOEs. From this table a different picture emerges. True, the governments of emerging economies are also non-trivial part-owners of enterprises, but the majority of PSOEs (sixteen out of the 25) are located in OECD countries. A raft of European governments, in particular, has retained significant minority stakes in large listed companies. For example, France and Germany appear prominently.

${ }^{2} \mathrm{ENI}$ is $30 \%$ state-owned, but the Italian government is entitled to appoint the majority of board members (Christiansen and Kane, 2013). 
Table 2. The world's largest 25 PSOEs in the business year 2012-13 (US\$ billion)

\begin{tabular}{|c|c|c|c|c|c|c|}
\hline $\begin{array}{c}\text { Global } \\
\text { rank }\end{array}$ & Company & Sector & Domicile & $\begin{array}{c}\text { Market } \\
\text { value }\end{array}$ & Sales & Assets \\
\hline 14 & Volkswagen Group & Auto industry & Germany & 94.4 & 254.0 & 408.2 \\
\hline 22 & BNP Paribas $^{3}$ & Banking & France & 71.3 & 126.2 & 2504.2 \\
\hline 47 & NTT & Telecom & Japan & 58.2 & 126.9 & 226.0 \\
\hline 54 & Bank of Communications & Banking & China & 56.7 & 43.5 & 846.4 \\
\hline 87 & Vale & Iron \& Steel & Brazil & 92.7 & 45.7 & 130.4 \\
\hline 95 & GDF Suez & Utilities & France & 45.0 & 128.0 & 268.9 \\
\hline 101 & China Merchants Bank & Banking & China & 44.1 & 28.4 & 547.0 \\
\hline 107 & China Minsheng Banking & Banking & China & 43.9 & 27.9 & 515.5 \\
\hline 118 & Nordea Bank $^{4}$ & Banking & Sweden & 47.1 & 23.2 & 892.6 \\
\hline 125 & Shanghai Pudong & Banking & China & 31.6 & 25.4 & 504.5 \\
\hline 135 & EADS & $\begin{array}{c}\text { Aerospace \& } \\
\text { Defense }\end{array}$ & Netherlands & 46.0 & 74.5 & 115.5 \\
\hline 145 & $\mathrm{ENEL}^{5}$ & Electricity & Italy & 32.2 & 111.9 & 226.3 \\
\hline 169 & France Telecom & Telecom & France & 29.2 & 57.4 & 113.9 \\
\hline 175 & Renault & Auto industry & France & 20.3 & 54.4 & 98.9 \\
\hline 190 & Deutsche Post & Postal & Germany & 29.4 & 73.2 & 45.0 \\
\hline 191 & Japan Tobacco & Tobacco & Japan & 61.6 & 24.6 & 43.0 \\
\hline 219 & DNB & Banking & Norway & 26.5 & 14.4 & 406.8 \\
\hline 240 & China Everbright Bank & Banking & China & 21.0 & 13.5 & 275.1 \\
\hline 275 & DBS Group & Banking & Singapore & 30.7 & 8.8 & 288.9 \\
\hline 294 & CNP Assurances & Insurance & France & 9.9 & 53.2 & 466.1 \\
\hline 304 & ÖMV Group & Oil \& Gas & Austria & 14.7 & 56.3 & 39.8 \\
\hline 368 & Safran & $\begin{array}{c}\text { Aerospace \& } \\
\text { Defense }\end{array}$ & France & 19.6 & 18.0 & 30.0 \\
\hline 391 & Lloyds Banking Group & Banking & U.K. & 53.8 & 75.6 & 1495.9 \\
\hline 433 & Deutsche Telekom & Telecom & Germany & 48.4 & 76.7 & 136.1 \\
\hline 456 & Bharti Airtel & Telecom & India & 21.8 & 14.0 & 29.8 \\
\hline
\end{tabular}

Source: Forbes 2000 and Christiansen and Kane (2013)

Combining Tables 1 and 2 leads to the conclusion that the State in various countries yields dominant or significant influence in at least 22 of the world's 100 largest corporations. Smaller companies can of course also be SOEs and PSOEs, but a full analysis of the Forbes 2000 database reveals a clear size bias. The smaller an enterprise, the lower is the likelihood of state ownership. Of the world's 2000 largest companies, 282 are found to be state-invested enterprises (SIES).

The question that proposes itself is whether a significant, and apparently growing, weight of SIEs in the corporate landscape poses challenges for policy makers and regulators. On the one hand it is neither surprising nor onerous that big and fast-growing emerging economies with large SOE sectors begin to appear more visibly in the corporate league tables. On the other hand, OECD countries have undertaken extensive reform of their national SOE sectors over recent decades

${ }^{3}$ The Belgian government retains a $10 \%$ shareholding in BNP Paribas which dates back to the rescue operation of Fortis Bank.

${ }^{4}$ Nordea Bank was privatised in 2013.

${ }^{5}$ ENEL might arguably be classified as SOE since the Italian state (like in the case of ENI) wields significant powers over board nominations. 
(indeed several governments would concede to have important unfinished business) and there is a risk that the large state-owned firms that have appeared in the corporate landscape may be weighed down by beset by many of the same problems.

The reform priorities that have been addressed in recent decades included a lacklustre operational efficiency of SOEs (and to a much lesser extent PSOEs) as well as an excessive politicisation of the operational objectives of some of these companies. Both have been addressed by governments through a combination of privatisation and reforms of the ownership and governance of SOEs in accordance with the recommendations laid down in the OECD Guidelines on Corporate Governance of State-Owned Enterprises. Another area of concern is the effect that SIEs can have on the competitive landscape in which they operate. Even efficient and well governed enterprises may occasionally be tasked by their government owners with noncommercial objectives, which can have wide ranging consequences throughout the national or global marketplace. Some of these concerns are further elaborated in the following section.

A related issue is whether the impact of an increasing presence of SIEs is predominantly felt in these enterprises' domestic economy or is of broader, global consequence. This, in turn, depends on the extent to which they compete with foreign companies through participation in international trade, investment in foreign jurisdictions as well as competition in third markets. An extensive analysis of SOEs and international trade was undertaken by the OECD Trade Committee (Kowalski et al., 2012). It found significant links between national and sectoral concentrations of state-owned enterprises and international trade activities, but could not on the basis of existent data link this conclusively to the overseas activities of individual SOEs.

An earlier study by the OECD Working Party on State Ownership and Privatisation Practices, based on partial and anecdotal evidence from OECD some emerging market economies, concluded that there is no widespread or general evidence of an accelerated internationalisation of SOE activities. The cases where SOEs are particularly active in international trade and investment generally fall into three categories: (1) SOEs are located in sectors where all enterprises, including the private competition, operate internationally (e.g. the hydrocarbons and mining sectors); (2) there has been a wave of cross-border consolidations in the public utilities sectors in the EU area, which in many cases has involved SOEs; (3) Chinese SOEs in particular have been encouraged by their government to expand abroad as part of the so-called "go global" policy introduced more than a decade ago.

The latter point has unsurprisingly been perceived as onerous by some observers. However, a couple of observations deserve mentioning. First, the corporate sectors in countries with large current account surpluses have traditionally emerged as major outward investors. This has in the past for example been the case in Japan and Switzerland - the main difference being that most of the Chinese companies with capacity to expand abroad tend to be state-invested. Secondly, the "go global" policy seems to follow in the footsteps a number of other Asian economies. Japan and several ASEAN economies have developed their domestic industrial sectors amid a degree of state interventionism. In many cases the respective governments perceived the ability to compete internationally as one of the key performance criteria for a successful enterprise. However, with the exception of Singapore, they relied significantly less on direct state ownership of enterprises than the Chinese government (this was discussed at some length in OECD, 2013c).

Summing up, the relevant discussion is less about State ownership and internationalisation than about the operational and financial conditions under which SIEs compete with private and foreign companies. The remainder of the paper is structured as follows. Section II takes stock of 
previous work by OECD to identify possible concerns about state-owned enterprises in the international economy; Section III compares the operational performance and financing of the world's largest SIEs in five key sectors (mining, oil\&gas, air transport, telecom and electrics utilities) with comparable private enterprises; Section IV analyses the international investments of SIEs in the same sectors over the last 15 years; Section $V$ concludes and proposes directions for follow-up and future work. 


\section{PUBLIC-PRIVATE COMPETITION: CONCERNS AND CHALLENGES}

As a starting point it must be recognised that the notion of state-owned enterprises operated according to totally commercial principles is in most cases "a pie in the sky". Even privately owned companies may pursue objectives that are not wholly commercial. In the case of SOEs the reason the state has decided to remain as (majority) owner is logically that those enterprises are expected to behave differently from what private entities might do.

The question, then, is whether the state's objectives can be pursued in a manner that does not impair the competitive landscape. According to "textbook economics" this is mostly possible when the state intervenes in the economy with the purpose of remedying market failure. In practice this argument is most convincingly brought forward in favour of SOEs in sectors with a strong element of natural monopoly, the potential abuse of which by private operators would be difficult to address through regulation. A variation of the externalities argument, which is particularly relevant in the light of the many commercially operating SOEs in emerging economies, relates to the use of SOEs as agents of developmental policies. The use of SOEs to develop certain economic activities for which, at the outset, there is no market in order to nurture private commercial activities can also be portrayed as an effort to correct externalities.

The OECD Guidelines on Corporate Governance of State-Owned Enterprises does not discourage such practices, provided there is full disclosure about the public policy objectives that SOEs are requested to pursue, and the associated costs are covered by the national treasury in a transparent manner. However, this argument is of a somewhat "national" character - based on an implicit assumption that the general public that is expected to benefit from SOEs' public policy objectives consists of the same individuals who will carry the costs. Where SOEs engage in cross-border competition, issues can become somewhat more complex. Recent evidence from OECD economies suggests - in addition to remedying demonstrated market imperfections - at least four main reasons why governments may sometimes make a conscious decision to depart from commonly accepted commercial practices in their SOE sectors (see also Capobianco and Christiansen, 2011). These are briefly suggested below:

- Maintaining public service obligations. The most commonly heard rationale for protecting SOEs from "excessive" competition occurs in the network industries and relates to these companies public service obligations - such as maintaining postal and telecommunication services in outlying areas, providing essential utilities at affordable rates, etc. From a strictly economic perspective this does not imply that these companies must remain in the public domain as these objectives could be similarly met through targeted subsidies. (In effect the SOE Guidelines says that they should be, if the company remains in public ownership.) However, it is often seen by public planners as easier to continue providing public services through fully controlled entities. On a slightly more onerous note, continued state ownership also provides an opportunity for crosssubsidisation areas - e.g. by charging excessive revenues in certain "lucrative" areas in order to be able to fund the public service obligations elsewhere. In addition to their effects on the competitive landscape such practices also fall short of commonly agreed standards of transparency. However, they appear to be quite widespread. On numerous occasions, the first opening of segments of any given network industry to market competition has given rise to accusations of unfair "cherry picking" by the entrant. Taken literally this does seem to indicate that the activities concerned were previously used to generate extraordinary profits that could be used to cross-subsidise other activities. 
- SOEs as a tool for industrial policy and national development strategies. Relatively few OECD countries these days appear to be assigning a pro-active industrial policy role to their SOEs sectors - such as, for example, obligations to develop certain capabilities or pursue knowledge and technologies in the broader national interest. Conversely, the practice has remained commonplace in several emerging economies. In countries at low levels of development SOEs are sometimes seen by governments as the only alternative to having no enterprises in a certain sector. At later stages of the development process SOEs may be tasked with developing politically prioritised economic activities or contribution to the formation and dissemination of commercial knowhow. Regardless of levels of development many countries also seem to attach "defensive qualities" to their state ownership, aiming to maintain companies alive and in state hands because of fears of no longer having a national champion in certain economic sectors. Some of the considerations motivating the internationalisation of SOEs point in that direction. Several governments encourage foreign operations of state-owned incumbents in the network industries "to protect their revenue streams" faced with increasing domestic competition. This motivation makes sense only in a context where the state attaches societal value to the maintenance of a state-owned company in the respective sectors. Governments may differ in respect of whether stateownership is a goal in itself or a tool for preventing a foreign takeover.

- Protecting fiscal revenues. Some SOEs provide consistently large profits (or in some cases revenues) on which the national treasury comes to depend. This has most frequently been the case in the extractive industries, but is also not uncommon in the utilities sectors. From a competition viewpoint this may be particularly problematic, because not only does it imply that the government has a strong incentive to shield of such SOEs from competition, the high revenue stream itself may depend on monopoly rents.

- The political economy of SOEs. Policy makers sometimes feel they need to protect SOEs because of pressures from interest groups or the general public. For instance, SOEs remain a major source of employment in many OECD countries. Also, SOEs are often seen as offering civil service status or higher paid jobs - especially for blue collar employees - and in some countries have more generous retirement arrangements than the private sector. Any failure of the State to shield its enterprises from competition from companies decried as "low-wage" or "not maintaining adequate standards of corporate responsibility" could expose politicians to strong public pressures. Whilst formally related to democratic accountability, such mechanisms have the potential to be used by rentseeking insiders to stifle competition

Finally, even where governments limit themselves to using SOEs to remedy market imperfection the cross-border dimension of commercial activities may lead to some adverse effects. For example, in sectors with strong economies of scale compensating enterprises for an inefficiently small size would qualify as an effort to overcome market failures. However, in an internationally operating industry where the (larger) competitors are domiciled abroad this would most likely trigger a hostile reaction from other governments and, where cross-border trade is involved, could fall foul of international treaties. Similarly, protecting a natural monopoly from a potentially destabilising failure would, even if it might perhaps be justified by longer-term economic considerations, be considered as hostile and disruptive by potential foreign market entrants. 


\section{Advantages (and disadvantages) of state ownership}

An additional concern arises from the fact that many governments in practice choose to compensate SOEs for non-commercial priorities in other ways than through carefully calibrated fiscal outlays. It should, however, be noted that a number of governments fail to do this. SOEs, even where exposed to direct competition with private companies, sometimes find themselves as a competitive disadvantage due to the fact that they are either insufficiently compensated for the public policy objectives they are formally instructed to pursue, or because of ad-hoc political interventions in their operations. In addition, some commercial entities may also be operating inefficiently because - e.g. reflecting political constraints - they have not been given an appropriate legal form or otherwise are insufficiently separated from general government.

On the other hand, SOEs may enjoy privileges and immunities that are not available to their privately-owned competitors, which can provide a competitive advantage over their rivals. Such advantages are not necessarily based on better performance, superior efficiency, better technology or superior management skills but are merely government-created and can distort competition in the market. For example:

- $\quad$ Outright subsidisation. Some SOEs receive direct subsidies from their government or benefit from other public forms of financial assistance to sustain their commercial operations. For example, the favourable tax regimes or exemptions from certain taxes that are enjoyed by SOEs are tantamount to selective government subsidies. Another form of subsidisation is in-kind benefits, for instance where state-owned operators in the network industries receive benefits such as land usage and rights of way at a price significantly below what private competitors would have had to pay in like circumstance. These exemptions artificially lower the SOEs' costs and enhance their ability to price more efficiently than competitors subject to a full tax regime.

- Concessionary financing and guarantees. SOEs may enjoy credits directly from governments, or provided via state-controlled financial institutions, at below-market interest rates. A related area is explicit or implicit state guarantees for SOEs, which reduce their cost of borrowing and enhance their competitiveness vis-à-vis their privately-owned rivals. This anti-competitive effect may be somewhat more "accidental", in that it is perfectly rational for commercial lenders to lower their rates when the debtor is perceived as enjoying state backing, and it may in practice be difficult for the state to convince markets that a given enterprise is not subject to such guarantees. Conversely, the presence in OECD countries of a number of SOEs with negative book equity values may serve as an illustration of the continued importance of government guarantees. Moreover, SOEs of some sectors and/or some corporate forms may enjoy outright exemptions from bankruptcy rules.

- $\quad$ Other preferential treatment by government. In some cases, SOEs are not subject to the same costly regulatory regimes as private firms, lowering their operating costs. According to the national context, these exemptions may, for example, include compliance with disclosure requirements and exemptions from antitrust enforcement, building permit regulations or from zoning regulations. Moreover, notwithstanding the relatively stringent public procurement rules of most OECD countries, some SOEs may in practice continue to benefit from preference in public procurement. This may not necessarily reflect onerous practices at the level of general government - merely an accumulated competitive or informational advantage allowing SOEs to tailor their offers more closely to government requirements. SOEs may also benefit from more general 
information asymmetries, by having access to government information or data which are not available to their private competitors or only available to a limited extent.

- Monopolies and advantages of incumbency. In many cases, governments entrust SOEs with exclusive or monopoly rights over some of the activities that they are mandated to pursue. This can be seen, for example, in postal services, utilities and other universal services that the state decided to pursue through state-controlled entities. Where SOEs continue to benefit from a legal or natural monopoly this may be of little practical consequence for the competitive landscape, but a number of SOEs in the network industries operate as vertically integrated structures with incipient monopolies in parts of their value chains. This can have a direct effect on relative competitiveness, and it may also allow them to influence the entry conditions of would-be competitors across a number of commercial activities.

- Captive equity. SOEs' equity is generally "locked in", i.e. in other words control of an SOE cannot be transferred as easily as in privately-owned firms. The inability to transfer ownership rights will result in a number of advantages for SOEs, such as: (i) some SOEs are generally absolved from paying dividends or indeed any expected return to shareholders ; (ii) SOEs will be more inclined to engage in anti-competitive (and rarely profitable) exclusionary pricing strategies, such as predation, without fear of falling stock prices when losses are incurred due to the below-cost pricing; and (iii) SOEs' management will have less incentives to operate the company efficiently as it is not subject to the threat of takeovers and generally impervious to the disciplining effects of capital markets.

- Exemption from bankruptcy rules and information advantages. SOEs often enjoy exemptions from bankruptcy rules. Because equity capital is locked, SOEs can generate losses for a long period of time without fear of going bankrupt. In addition, SOEs may also benefit from information asymmetries. Information asymmetries occur when SOEs have access to data and information which are not available to their private competitors or only available to a limited extent.

\section{Ensuring a level playing field}

To respond to these challenges OECD recently developed a "best practice report" identifying priority areas for policy makers that are committed to maintaining a level playing field commonly referred to as "competitive neutrality" - between SOEs and private enterprises (OECD, 2012 and OECD, 2013a). The report was based on a large body of earlier OECD studies, guidelines and best practices which, while not directly addressing competitive neutrality, have a bearing on the subject. The main conclusion is that governments wishing to obtain and enforce competitive neutrality need to focus attention on the following seven priority areas:

- Streamline government businesses either in terms of corporate form or the organisation of value chains. An important question when addressing competitive neutrality is the degree of corporatisation of government business activities and the extent to which commercial and non-commercial activities are structurally separated. Separation makes it easier for commercial activities to operate in a market-consistent way. Incorporating public entities having a commercial activity and operating in competitive, open markets, as separate legal entities enhances transparency.

- Ensure transparency and disclosure around cost allocation. Identifying the costs of any given function of commercial government activity is essential if competitive neutrality is 
to be credibly enforced. For incorporated SOEs, the major issue is accounting for costs associated with fulfilling public service obligations (if applicable). For unincorporated entities, problems arise where they provide services in the public interest as well as commercial activities from a joint institutional platform.

- Devise methods to calculate a market-consistent rate of return on business activities. Achieving a commercial rate of return is an important aspect in ensuring that government business activities are operating like comparable businesses. If SOEs operating in a commercial and competitive environment do not have to earn returns at market consistent rates then an inefficient producer may appear cheaper to customers than an efficient one.

- Ensure transparent and adequate compensation for public policy obligations. Competitive neutrality concerns often arise when public policy priorities are imposed on public entities which also operate in the market place. It is important to ensure that concerned entities be adequately compensated for any non-commercial requirements on the basis of the additional cost that these requirements impose.

- Ensure that government businesses operate in the same or similar tax and regulatory environments. To ensure competitive neutrality government businesses should operate, to the largest extent feasible, in the same or similar tax and regulatory environment as private enterprises. Where government businesses are incorporated according to ordinary company law, tax and regulatory treatment is usually similar or equal to private businesses.

- Debt neutrality remains an important area to tackle if the playing field is to be levelled. The need to avoid concessionary financing of SOEs is commonly accepted since most policy makers recognise the importance of subjecting state-owned businesses to financial market disciplines. However, many government businesses continue to benefit from preferential access to finance in the market due to their explicit or perceived government-backing.

- $\quad$ Promote competitive and non-discriminatory public procurement. The basic criteria for public procurement practices to support competitive neutrality are: (1) they should be competitive and non-discriminatory; and (2) all public entities allowed to participate in the bidding contest should operate subject to the above standards of competitive neutrality.

In a cross-border context there is little doubt that a portmanteau commitment to competitive neutrality such as outlined above would eliminate almost all concerns about the operating conditions of foreign SOEs. What is perhaps less clear is whether such an approach would be efficient - or even feasible - in the global political economy. Ongoing negotiations of international trade and investment treaties have grabbled with the role of SOEs, and one of the topics for discussion has reportedly been whether it would be more efficient to concentrate on subsidised SOEs operating abroad rather than aim for a broader neutrality commitment. At issue is, first, the difficulty in assessing and regulating intangible advantages that an internationally active SOE may enjoy such as, for example, regulatory forbearance and a privileged position in the domestic economy. Also, at the political level there seems to be limited appetite for a broad commitment that would apply the competition in the domestic economy between foreign entrants and purely national SOEs. 
Hence, while competitive neutrality is a useful reference point - domestically and to assess the commercial orientations of other countries' SOEs - some more narrowly focused approaches may in practice be called for. One area that has been frequently brought up in the debate about internationally expanding SOEs is their cost of funding and financing. This is discussed in some details in the following sub-section.

\section{Funding and financing of SOEs}

The OECD Working Party on State Ownership and Privatisation Practices recently undertook a study of the way in which state-owned enterprises in the Organisation's member countries fund their operations and investments (OECD, 2014). A main finding from this report was that authorities in an average OECD country actually approach the issue of financing SOE operations with quite a high degree of professionalism. This contrasts with the experience of previous decades where SOEs were sometimes perceived either as "fiscal sinks" where hidden reserves could be parked, or "milk cows" to be exploited as a source of revenue to the point where their viability was seriously imperilled. This confirms a tendency explored by other publications by the Working Party (e.g. OECD, 2011) which have found that recent SOE reform has largely moved national practices closer to commonly agreed standards. However, in the context of the current paper it bears mentioning that anecdotal evidence abounds that practices pursued in enterprises controlled by sub-national levels of government in a number of OECD countries are far less progressed with their reform processes.

While the state ownership functions and individual SOEs may have become more "professional" and approached themselves to the practices in similar private enterprises, it is also fair to say that no single model has emerged. For instance, only a minority of OECD's member countries systematically engage in assessments of the appropriateness of SOEs' capital structure, but a significant additional number make implicit decisions to a similar effect through evolving rate-ofreturn requirements and dividend policies. Only a minority of countries make such decisions purely or largely on an ad-hoc basis. Most OECD governments retain the option of redressing the capital/debt balance of SOEs through the infusion of direct subsidies, but - inter alia reflecting the strictures of WTO rules and, in many cases also the EU Single Market - generally reserve this for SOEs that are assigned special public policy obligations.

Most OECD area governments retain the option of recapitalising their SOEs - through share issuance, debt-equity swaps or, in the case of wholly-owned enterprises, infusion of funds. In most cases this is apparently motivated by a need to fund additional capital formation by the SOE, but it may also reflect a need to address excessive leverage (e.g. in case of initially too optimistic profit expectations and dividend policies) or, in rarer cases, to stave off a threatening corporate failure.

State-owned enterprises in OECD countries generally obtain most of their debt finance from privately owned banks. Only some of the largest and most commercially operating companies issue tradable debt, and quite a few SOEs that could profitably do so seem to refrain because of concerns about the additional corporate governance and reporting requirements that this entails under securities rules. Conversely, some of the SOEs that have issued corporate bonds have done so specifically in connection with their owners' efforts to upgrade their governance. Some governments which make treasury loans available to SOEs (one even demands that SOEs raise debt finance only from the national Treasury) generally have rules in place to ensure market consistency of interest rates and conditions. Loans from state-owned financial institutions are generally available only under circumstances (e.g. export credit; development banks) where a certain subsidisation would be available to private companies in like circumstances. The 
conclusion therefore offers itself that SOEs in OECD countries generally borrow money on market-consistent terms.

That said, the relative sound financial operating environment in most OECD countries, including recent improvements, should however not lead to the conclusion that there are no remaining problems to be addressed. Again, from a competitive neutrality perspective some areas of concerns offer themselves. As in other cases this is particularly the case in SOEs that pursue both commercial and non-commercial priorities and are unable to account separately for the cost structures of the two sets of activities. Based on the findings of the present report they include:

- Rates of return. Perhaps the most important outstanding issue is the trouble with monitoring whether rate-of-return requirements imposed on SOEs are comparable with those demanded of private enterprises. Even in an ideal situation this would be problematic since rate-of-return measures necessarily need to be considered over a long time span. In the case of OECD countries' current practices it is potentially more serious as a majority of countries, by their own admission, do not impose rate-of-return requirements on their wholly state-owned enterprises. Some governments moreover appear to compensate SOEs for having to assume public policy functions (rather than through a carefully calibrated subsidy) by negotiating relatively low rates-of-return, effectively providing these enterprises with a perverse incentive to expand in the market place.

- Recapitalisation. The conditions on which recapitalisation is offered to (wholly-owned) SOEs is notoriously difficult to assess empirically. Some disciplines on the conditions of recapitalisation exist, including the EU Commission's demand that practices may not differ from private enterprises in like circumstances. However, such requirements can be difficult to enforce in practice, including in cases where recapitalisation efforts may be conducted in unison with private investors acting in concert with governments.

- Perceived guarantees. Finally, an indisputable advantage enjoyed by SOEs across OECD countries (with the possible exception of Australia) lies in the fact that their ownership puts them in a lower risk category in the eyes of other market participants. Actual lending to SOEs may be undertaken on market terms by commercial lenders, but the latter almost invariably perceive state-owned enterprises as more credit-worthy than their private competitors. Explicit guarantees to SOEs are rare within the OECD area, but credit ratings and interest rate differentials indicate that financial market participants in many cases perceive guarantees. This provides SOEs with a competitive advantage already in their domestic activities, and if the low interest rates can be retained to finance more risky overseas expansions then the advantage is further compounded when SOEs operate abroad. 


\section{PERFORMANCE AND FINANCING OF THE WORLD'S LARGEST SOES}

This section employs firm specific data to investigate the performance and financing patterns of SIEs. Using the Forbes $\odot$ Global 2000 list of companies from 2013, we compare SIEs with private firms in five sectors where state ownership is perceived to be particularly widespread: oil and gas, mining, air transportation, power generation and telecommunication. Here, SIEs mean companies where the central government, or in the case of federal structures, autonomous subnational levels of government, have at least $10 \%$ ownership of the voting shares.

\section{The Forbes( $\subseteq$ Global 2000 and the OECD corporate database}

For the five sectors under consideration ${ }^{6}$, there are 335 firms among the 2000 largest enterprises in the world. Table 3 provides their break down by sector and according to their SIE status (see Table A1 in the Annex for the full list). A total of 112 firms are SIEs, with 104 being from non OECD economies, representing 49 different countries. In particular, the sample covers 33 companies from China, 17 from Russia and 13 from India. Moreover, more than 70\% of nonOECD companies in Forbes Global within the five sectors are SIES, while this is only the case for $17 \%$ of the companies domiciled in the OECD area.

Table 3. Distribution of companies by sector and according to their SIE status

\begin{tabular}{lcccccc}
\hline & \multicolumn{2}{c}{ Ownership: } & \multicolumn{2}{c}{ Region: } \\
\hline Industry & Percent & Private & SIEs & $\begin{array}{c}\text { Non- } \\
\text { OECD }\end{array}$ & OECD & Total \\
\hline Airline & 6.87 & 15 & 8 & 5 & 18 & 23 \\
Diversified Metals \& Mining & 18.51 & 45 & 17 & 25 & 37 & 62 \\
Electric Utilities & 25.37 & 51 & 34 & 24 & 61 & 85 \\
Oil \& Gas Operations & 29.25 & 70 & 28 & 25 & 73 & 98 \\
Telecommunications services & 20.00 & 42 & 25 & 25 & 42 & 67 \\
\hline Total & 100 & 223 & 112 & 104 & 231 & 335 \\
Source: OECD Secretariat and Forbes Global 2000 & & & & &
\end{tabular}

To analyse the performance and the financing structure of these firms, firm-level information has been extracted from an OECD corporate database taking as its point of department from Bureau Van Dijk publishing (BvDEP) that contains financial and ownership information for over 44 million companies across the world, with more than 200 variables. The OECD corporate database is the output of treatment of the raw data provided by Bureau van Dijk to the OECD, involving a consortium of 8 directorates using the data for various projects involving firm-level cross-country analysis. With the corporate database, OECD has analysed a variety of issues such as productivity growth, export performance, innovation or international investment consistent with methodologies previously applied in economic literature (Peter N Gal, 2013, A Ragoussis and E Gonnard, 2012, Samuel Pinto Ribeiro et al., 2010). The database has also often been used to calculate mark-ups or price-cost margins.

The company information in the OECD corporate database is includes firm-specific details that, in principle, do not change from one year to another, such as the company name, its city and

\footnotetext{
${ }^{6}$ The five sectors have been selected from 80 industries classified in Forbes $@$ Global2000: http://www.forbes.com/global2000/ .
} 
country, as well as the core sectoral industrial activity of the firm (with four-digit NACE rev. 2 codes). ${ }^{7}$ The financial information is broken down into two major components: the firm's balance sheet and the profit and loss account reported for given time periods. The firm's balance sheet includes figures on the firm's assets, liabilities, its net value, as well as the number of persons the firm employs. The profit and loss account includes information on revenues, the costs of production of goods, financial expenses, taxation, and the firm's profits. The account is complemented by information on value added, the cost of employees and export turnover, on a non-systematic basis.

It has been decided to extract companies with the following criteria (See also Table A2 in the Annex):

- Geographic: OECD countries and 21 non-OECD economies ${ }^{8}$

- $\quad$ Status: Active main business unit without considering subsidies and affiliates

- Financial information: 10 years of consolidated statements from 2000 to 2010.

- Monetary data is expressed in ‘000 Euros (Thousand Euros).

- The amounts have been converted to constant 2005 US-dollars using the private final consumption expenditure deflator from the OECD Economic Outlook database.

\section{a) Profitability}

During the past few decades the pace of privatisation of SIEs around the world has continued apace, albeit with a significant slowdown during the current financial crisis. The privatisation of SOEs has generated large revenues for many governments and, perhaps even more importantly, it has provided a potential solution to the problem of inadequate SOE performance such as, transparency, agency problems and governmental interference. Despite the growing popularity of privatisation schemes, important questions remain for both researchers and policy makers, such as the effect of privatisation or reforming of SOEs on their profitability and margins.

Using the available information this section assesses the impact of ownership on the financial performance of SOEs. We use three indices to measure profitability: (i) return on total assets (ROA), which is defined as total profits (net income) divided by total fixed assets; (ii) return on shareholder funds, essentially identical to return on equity (ROE) which is defined as total profits divided by total shareholder funds; and (iii) return on capital employed (ROCE), which is defined as total profits divided by total shareholder fund plus non-current liabilities.

\footnotetext{
${ }^{7}$ For mining industry, NACE Rev. 2 = 510, 520, 710, 729, 899, 1310, 2059, 2441, 2444, 2445, 2454, 2811, 2932, 4211, 672, 6419, 6512, 7810; for air industry, NACE Rev. 2 = 1011, 2910, 4778, 4910, 5110, 5229, 6201, 6420; for electricity industry, NACE Rev. 2 = 520, 2059, 2711, 2815, 2910, 3511, 3512, 3513, 3522, 4211, 4719, 6020, 6190, 6420, 6619; for gas and oil industry, NACE Rev. 2 = 610, 910, 1200, 1910, 1920, 2016, 2059, 2892, 2899, 3511, 3512, 3530, 4671, 4730, 4950, 5223, 5510, 6419, 6420; for telecom industry, NACE Rev. $2=3511,6020,6190,6209,6419,6499,6500,6831$.

${ }^{8}$ Among non-OECD economies, all accession and key partner countries were included. So were a selection of other countries known where large SIEs in the five sectors are domiciled, including Saudi Arabia, Singapore and some other Asian economies.
} 
Figure 1. Performance by ownership and sector between 2000 and 2010

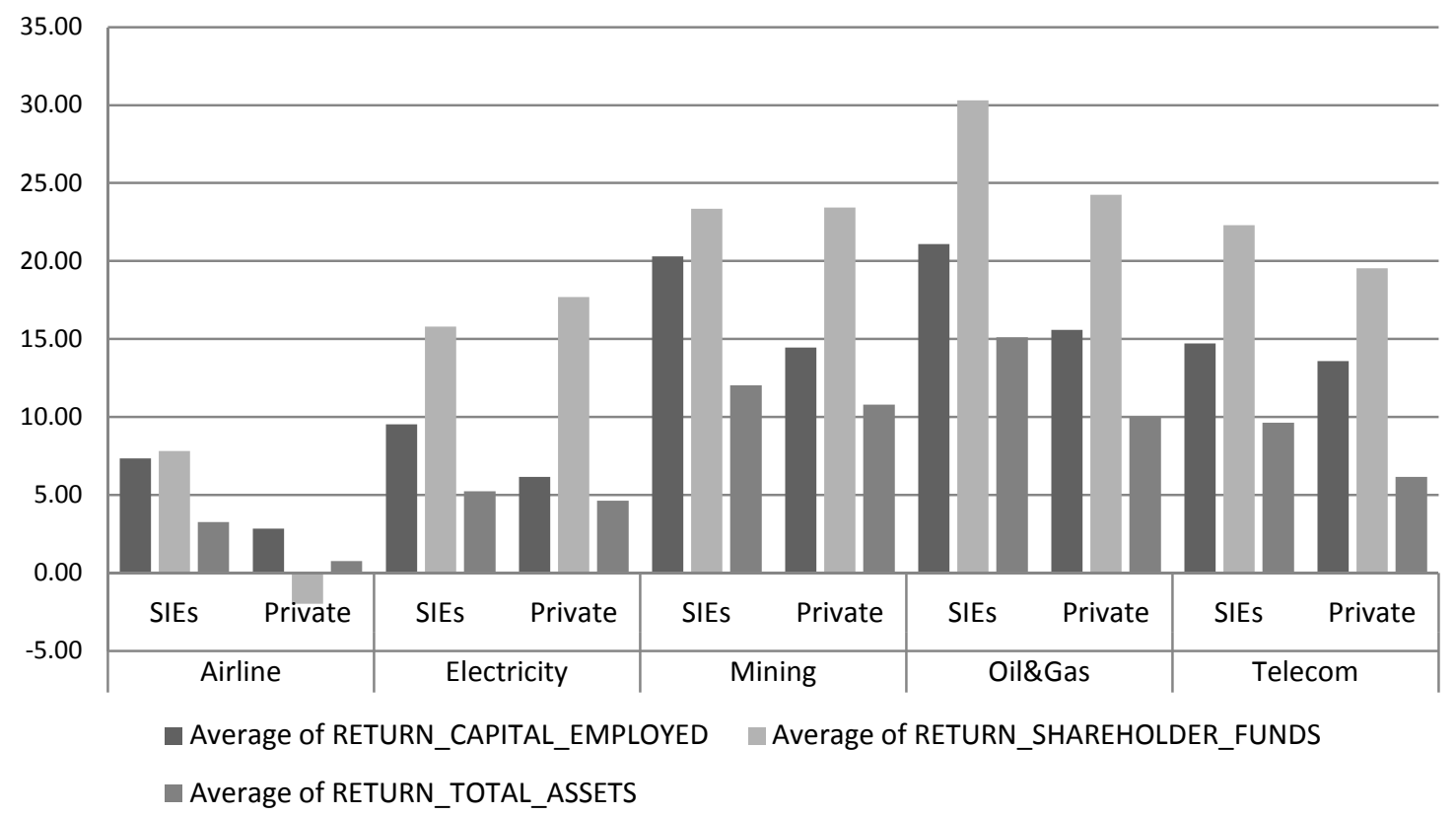

Source: OECD corporate database

Figure 1 provides an overview of the profitability of SIEs and private firms across sectors. Remarkably, in the airline industry the average profitability of private enterprises over the last decade appears to have been negative or close to zero. Conversely, state-invested airline have earned a certain - albeit modest - return on their investments. Generally, with respect to the return on assets and return on capital, the performance of SIEs is higher than private companies. Only in the case of electricity is there by some measures (though not including ROA) a higher degree of profitability in the private sector.

Looking at Figure 2 and the evolution of returns to total assets over years, there are interesting findings. First, the figure shows that there is more volatility in the ROAs of private firms. In particular, the effect of the financial crisis in 2008-2009 is more pronounced as compared to SIEs, despite the fact that the five sectors cover mostly network industries. However, we find that the private sector has recovered at a higher pace and profitability levels are closer to those of SIEs at the end of the period. Over the last 10 years, the profitability of the private sector has fluctuated but differences between SIEs and non-SIEs are getting smaller over years. Second, one might infer from the gradually more resilient returns in the private sector that these companies have become relatively less vulnerable to crises. Compare the episodes of turmoil in the 2000 s (2001/02 and 2008/09), the adjustment of private firms to the external shock is faster in the second case. 
Figure 2. Return to Total Assets over time

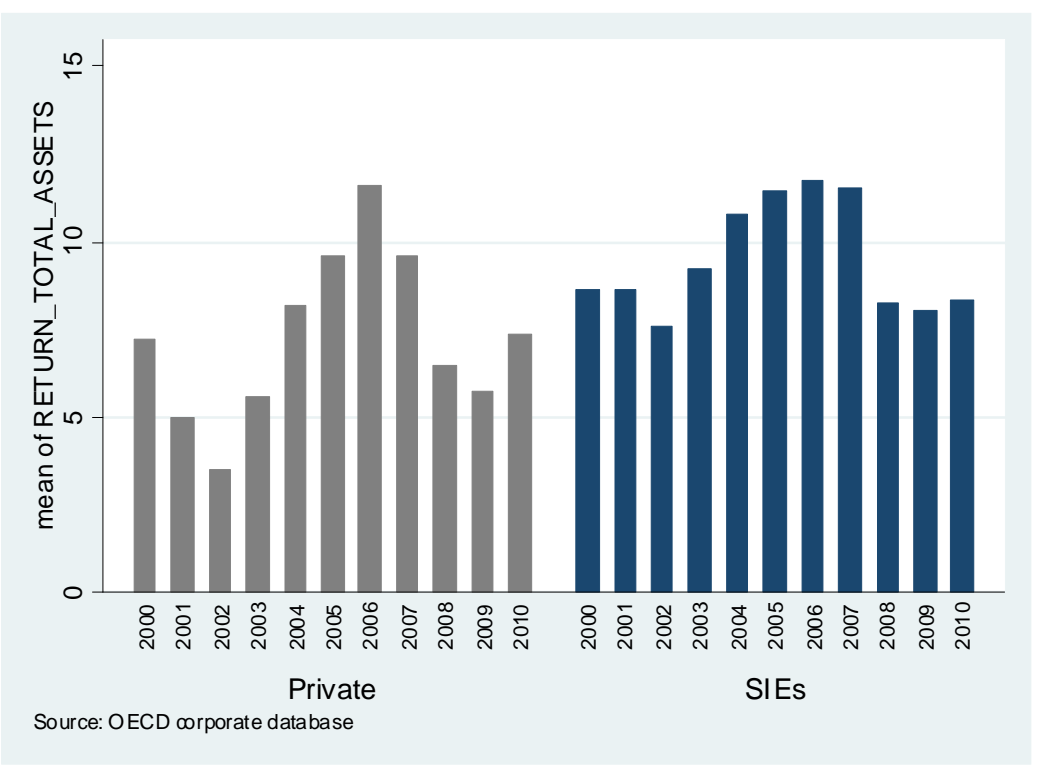

Summing up, it would appear that state-invested enterprises do not only tend to be more profitable than similar private firms, they also display less variability in their earnings. This could reflect a number of different factors, including access to cheaper funding, differently structured balance sheets, concessionary treatment by their government owners and/or greater market powers in the jurisdictions in which they operate.

\section{b) Funding and financing}

One factor that could bias the measures of economic return relative to assets or equity is if the liabilities of SIEs and private enterprises are structured differently. An overview is provided in Figure 3, which displays the trend in gearing ratios (debt equity relative to shareholders' funds expressed in percent) over the last decade. First, the figure shows that, on average, private companies in the five sectors have been more leveraged than SIEs during the period under review. However, other things equal this should have contributed to a higher ROSF in private companies than in SIEs, and the above documentation showed little indication of this. Secondly, the figure also illustrates a gradual reduction in the gearing of private companies in the five sectors, to a point where both they and the SIEs carry broadly equal amounts of equity and other liabilities. This is consistent with a broader trend toward corporate deleveraging since the beginning of the millennium. Thirdly, the figure appears to confirm a finding by OECD (2013) that the government owners of SOEs and other companies watch the debt/equity ratios of their companies closely and are quick to act in case of deviations from target values. The gearing of SIEs in the five sectors has been remarkably stable over the period under review. 
Figure 3. The comparison of gearing ratio (\%)

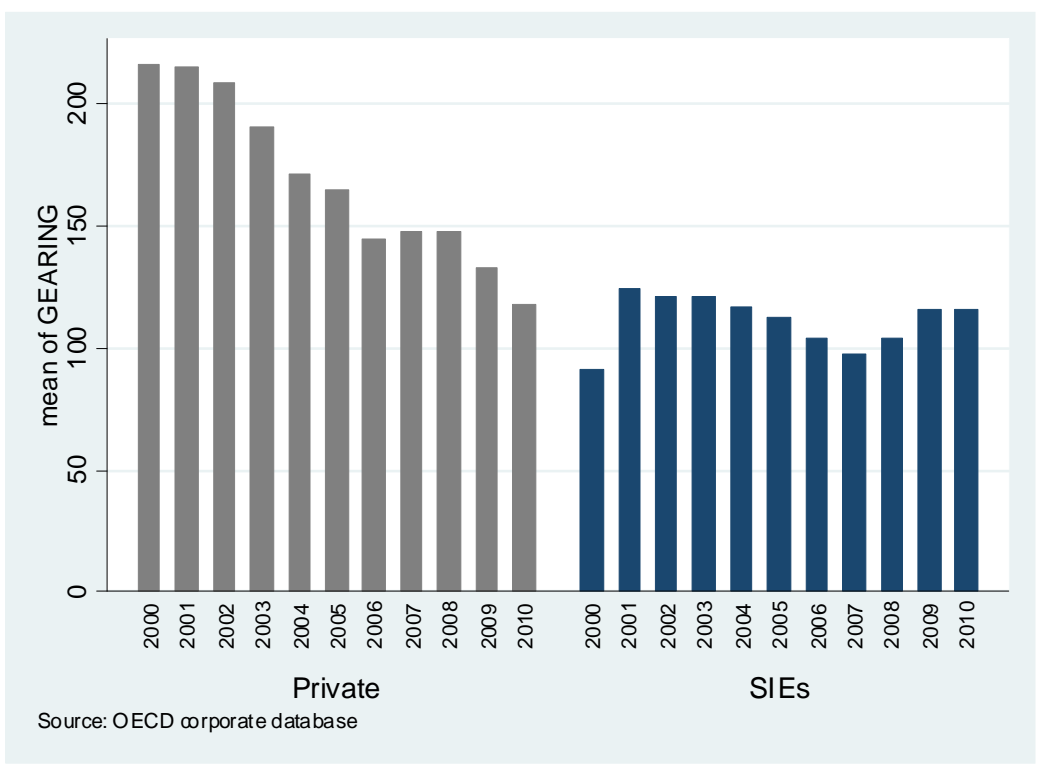

To shed light on the question of whether SIEs benefit from cheaper finance than private competitors, figure 4 shows the evolution over time of a measure of "effective interest rates" based on the company database. Caution in interpreting the figure is, however, called for: no data is available purely on interest-bearing liabilities. The figure displays an approximation calculated as total interest paid (from the company profit and loss account) relative to short and long-term non-equity liabilities. The latter include such items as supplier credits, tax arrears, etc. so insofar as there are systematic difference between SIEs' and private firms' approach toward such liabilities this is a source of systematic bias.

Figure 4 indicates little difference between the effective interest rates paid by large SIEs and private firms in the five sectors. In airlines, electricity and mining the differences are not statistically significant. Private oil and gas companies have, on average, paid less interest on their non-equity liabilities during the period under review, whereas in the telecom sector the opposite has been the case. All in all the evidence must be characterised as pretty inconclusive, which is perhaps related to the fact that the world's largest SIEs tend to be listed companies operating under financing conditions that may - contrary to smaller SOEs held closely by the State - not differ materially from their private counterparts. 
Figure 4. Effective Interest Rate

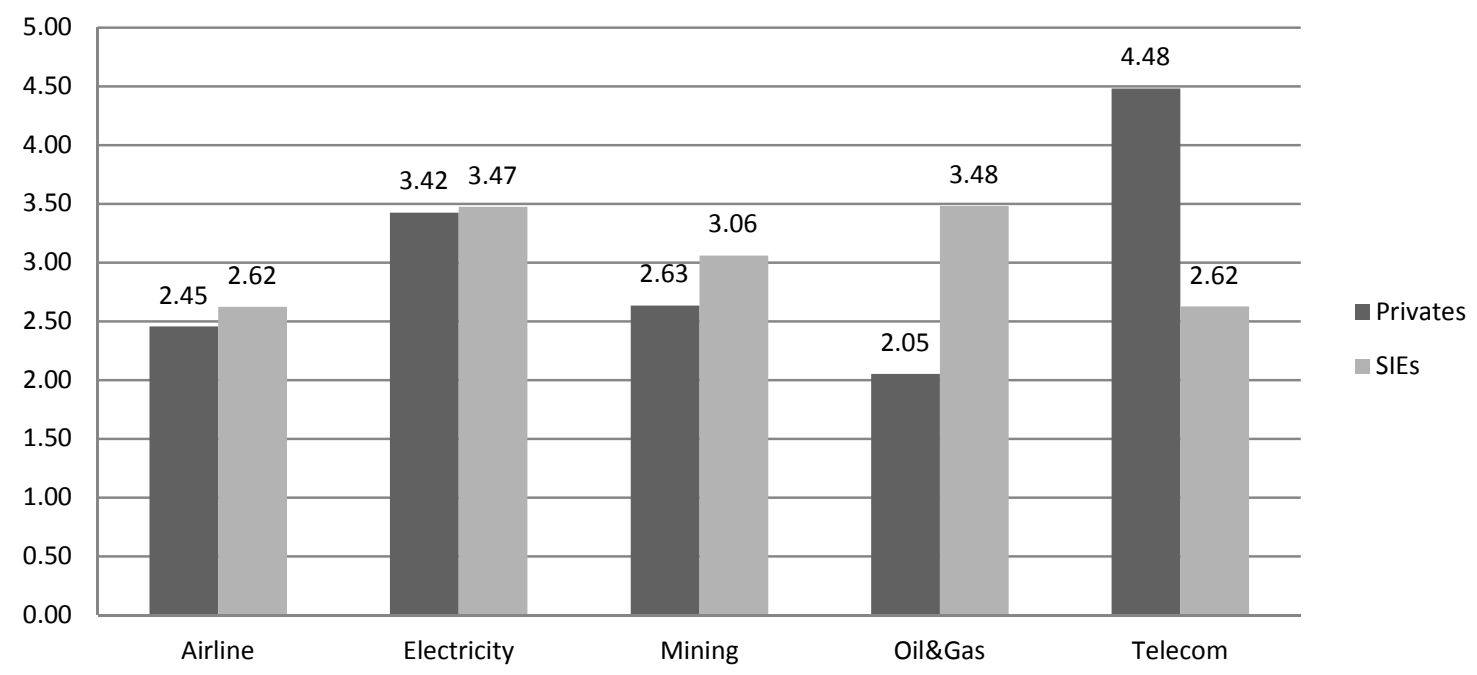

Source: OECD corporate database

\section{c) Indicators of margins and market power}

This section compares price costs margins across firms ${ }^{9}$, as well as other indicators of operating margins. One assumption is that the level of competition in an industry or the degree of privatisation has an impact on margins. In other words, the increased competition resulting from privatisations significantly reduces margins and the concentration of the market affects the price elasticity of demand.

Analysing price-cost margins assumes positive correlations between various measures of profitability at the industry level and concentration because the variation in margins will be different in concentrated and liberalised industries ${ }^{10}$. Hence, the analysis of concentration across sectors can explain the variation in margins, as highlighted in previous studies that have used price-cost margins to analyse the margin model (Keith Cowling and Michael Waterson, 1976, Ian Domowitz et al., 1986, Nikolaos P Eriotis et al., 2011, Stephen Machin and John Van Reenen, 1993).

Table 4 compares PCMs and other margin indicators by sector from 2000 to 2010. As would be expected given the low levels of return discussed above, in the case of air transportation there are lower EBITDA margins ${ }^{11}$, gross margins ${ }^{12}$ and profit margins ${ }^{13}$ than in other industries. This is,

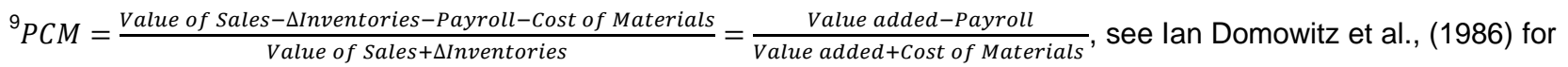
the more detail equations and assumptions.

10 There might be the omission of the industry price elasticity in country. However, considering PCM possibly reasonable to premise that the problem is less severe when we more consider the changed in structure effecting changes in performance; i.e., assuming the constancy if industry price elasticity by time is less critical than assuming that they are constant across industries (Cowling and Waterson, 1976).
}

${ }^{11}$ The EBITDA Margin $=\frac{\text { operating profit } / \text { loss }(\text { EBIT })}{\text { operating revenue }(\text { turnover })}$ 
among other things, almost certainly related to the greater degree of international competition in this sector affecting both private firms and SIEs. Even so, there is a clear indication of higher operating margins where the State is a significant owner, as well as some indications of greater market concentration (i.e. higher PCM).

Table 4. Comparison of PCM and other margin indicators by sector from 2000 to 2010

\begin{tabular}{|c|c|c|c|c|}
\hline & $\begin{array}{c}\text { Average of } \\
\text { EBITDA margin }\end{array}$ & $\begin{array}{l}\text { Average of } \\
\text { gross margin }\end{array}$ & $\begin{array}{l}\text { Average of } \\
\text { profit margin }\end{array}$ & $\begin{array}{c}\text { Average of } \\
\text { PCM }\end{array}$ \\
\hline Airline & 11.2 & 36.6 & 1.9 & 0.02 \\
\hline Private & 8.8 & 29.7 & 0.9 & 0.01 \\
\hline SIES & 16.1 & 49.3 & 3.8 & 0.03 \\
\hline Electricity & 31.1 & 52.9 & 14.8 & 0.10 \\
\hline Private & 27.9 & 53.3 & 12.9 & 0.03 \\
\hline SIES & 37.2 & 52.2 & 18.4 & 0.22 \\
\hline Mining & 30.4 & 41.1 & 19.5 & 0.02 \\
\hline Private & 31.1 & 41.3 & 19.4 & 0.02 \\
\hline SIES & 27.9 & 40.7 & 19.7 & 0.01 \\
\hline Oil \& Gas & 30.9 & 45.7 & 18.3 & 0.02 \\
\hline Private & 32.9 & 47.4 & 17.5 & 0.01 \\
\hline SIES & 26.4 & 41.7 & 20.1 & 0.05 \\
\hline Telecom & 36.2 & 63.7 & 12.8 & 0.05 \\
\hline Private & 33.8 & 61.0 & 9.5 & 0.04 \\
\hline SIES & 40.3 & 69.4 & 18.7 & 0.07 \\
\hline Grand Total & 30.5 & 49.6 & 15.3 & 0.05 \\
\hline
\end{tabular}

Source: OECD corporate database

The telecom sector has generally highest margins as compared to other sectors. This finding is perhaps unsurprising: the telecom sector was the scene of significant technological evolutions as well as rapidly growing penetration of fixed lines, mobile and internet services during this period. However, as the costs of funding the expansion were correspondingly high, this did not (as demonstrated above) result in abnormally high rates of return. In the telecom sector as well the gap between margins in SIEs and private firms is non-trivial. In the electricity and mining sectors, the difference between private firms and SIEs is not compelling, although on the whole earnings margins tend to be a tad higher when the state is involved.

The calculation of PCM confirms that SIEs appear to have greater market power. In particular, SIEs in the electricity sector have higher price-cost margins. A textbook explanation of this would be that producing additional electricity does not require important marginal costs and the elasticity of demand is very low.

\footnotetext{
${ }^{12}$ The Gross Margin $=\frac{\text { Gross profit }}{\text { operating revenue(turnover })}$

13 The Profit Margin $=\frac{\text { Profit } / \text { loss before tax \& extra items }}{\text { Operating revenue }(\text { turnover })}$
} 


\section{Summing up}

It appears from the above that the largest SIEs in the five sectors under review have indeed been more profitable than their private sector counterparts over the last ten years. Partly this may reflect the fact that a disproportionate number of them are domiciled in high-growth markets (e.g. in emerging economies), but some additional factors seem to be at play:

- Whereas advantages of state ownership in obtaining financing is well documented by OECD research, in the present sample of large and in many cases partially-state owned enterprises this does not appear to be a decisive factor behind SIEs' greater profitability.

- $\quad$ State-invested enterprises seem to enjoy generally higher profit and operating margins than similar private companies. Evidence based on mark-up margins surveyed in this section suggests that this reflects a generally higher concentration in the markets in which they operate ${ }^{14}$. If confirmed this would indicate that internationally operating SIES benefit largely from home markets were competitive pressures are weak - which might for example indicate concrete measures by their government owners to shield them from competition or a generally favourable market position due to incumbency.

\footnotetext{
${ }^{14} \mathrm{~A}$ competing, or supplementary, explanation might be that SOEs enjoy other unquantified advantages such as, for example, the use of free land and other resources.
} 


\section{INTERNATIONAL INVESTMENTS BY STATE-OWNED AND OTHER ENTERPRISES}

\section{Definitions and summary statistics}

Like the previous part of the report this chapter focuses on five sectors in which state control is relatively widespread: oil and gas extraction; mining; air transport; power generation and telecommunications. This chapter focuses on one aspect of the internationalisation and crossborder competition of such enterprises, namely the acquisition of foreign corporate assets through mergers and acquisition (M\&A).

The main source of information is the Dealogic database ${ }^{15}$. Dealogic records all "deals" defined as the transaction of a corporate asset. The asset types includes, broadly speaking, such assets as would appear on the acquirers' balance sheet, including fully or partly-owned incorporated entities, unincorporated production and distribution sites as well as physical assets such as mines and oilfields. Contractual rights such as concessions and patents are generally not included. All transactions taking place between 1998 and 2012 in the five sectors under consideration have been recorded. To establish the ownership (i.e. public versus private) of investors the data have been combined with information from the recent stocktaking of SOEs in OECD and partner countries ${ }^{16}$ as well as supplementary inputs from the "Ownership Module" of Thompson Financials database.

Some limitations following from the chosen methodology must be acknowledged:

- M\&As provide only a partial picture of corporations' internationalisation though investment. In developing countries in particular a sizeable part of inward corporate investment consists of "greenfield" transactions rather than takeovers of existent enterprises.

- The analysis is, to keep the amount of data manageable, limited to M\&As undertaken by companies operating in the five sectors under consideration. This implies that, for example, the acquisition of telecommunication assets by a company that is not itself located in the telecom sector is not included. This is potentially of some importance in the mining sector where a number of transactions have been undertaken, for instance, by metal producers as part of vertical integration strategies.

- That valuation of transactions according to Dealogic is often unclear, and for a large number of transactions the valuation is completely missing. (This is discussed at some length below.) For this reason, much of the analysis focuses on the number of transactions. Where valuation is addressed it must be kept in mind that the analysis is based on a truncated sample - which could be of particular importance where SOEs are involved as they may have less incentive to disclose pricing details than, for example, listed private corporations.

- Only transactions resulting in a subsequent ownership by the acquirer of at least $10 \%$ of the target have been included. This was done to exclude portfolio investment from the sample.

\footnotetext{
${ }^{15}$ The assistance of DAF/INV in obtaining an extensive amount of data from this source is gratefully acknowledged.

${ }^{16}$ See Christiansen and Kane (2013).
} 
The Dealogic database provides comprehensive information on international deals with the industry, region and main characteristics of the deal. It also frequently records information on the participants (acquirer, target and divestor), value of the deal, acquired and final stake and premium to target's shareholders. In total, 46, 045 deals involving 165 countries are covered over the last 15 years. In the five sectors of interest, 89.2 percent of the international acquisitions involve private companies, while 10.8 percent are deals involving SIEs. Limiting the dataset to the activity of SIEs reduces the number of countries to 58 .

With respectively 1,370 and 859 deals by SIEs, China and Russia are the most represented countries. Together they account for 45 percent of all international transactions of SIEs. More than half of the deals involve emerging markets. In the case of China, the activity of SIEs is twice as big as the activity of private companies. Among OECD countries, the top five countries with large SIEs' international transactions are France (415 deals), Italy (216 deals), Norway (205 deals), Japan (155 deals) and Germany (137 deals).

\section{a) Private and state-invested enterprises}

SIEs are defined as companies where the government at the central or federal level has at least 10\% ownership in 2012. (In federal nations some enterprises owned by States have, where information is available also been included.) The SIEs in the sample covering the five sectors are domiciled in 58 countries (see Table A3 in the Annex). They include companies listed on stock exchanges, wholly or partially-owned, non-listed companies and statutory corporations. Private enterprises are all the other companies. They can be fully owned by one person, partially listed with less than 10 percent shares for the state or fully listed in public with less than 10 percent shares for the state.

Of potential concern is the fact that this methodology allocates enterprises owned by regional and municipal authorities to the private sector. This is a particular problem in power generation where many of the main players are municipal undertakings. However, with a few exceptions these companies do not engage in cross-border transactions, so the classification problem is largely confined to domestic investments. Table 5 shows the ratio between private and SIES deals by type and by sector. The number of deals by private enterprises is 41,062 , representing 89 percent of the total.

Table 5. Number of deals by nationality and sector (1998-2012)

\begin{tabular}{lccc}
\hline & Domestic & International & Total \\
\hline Non-SIEs (Private deals) & 25,539 & 15,523 & 41,062 \\
\hline SIEs: & & & \\
Air & 104 & 84 & 188 \\
Electricity & 646 & 384 & 1,030 \\
Mining & 672 & 213 & 885 \\
Oil \& gas & 773 & 966 & 1,739 \\
Telecom & 487 & 654 & 1,141 \\
\hline Total & $28,221(61 \%)$ & $17,824(39 \%)$ & $46,045(100 \%)$ \\
\hline
\end{tabular}

Source: Dealogic 


\section{b) General and specific industry sectors}

To identify the industry of the acquirer, target and divestor, the Dealogic database provides a general industry group (GIG) and a specific industry group (SIG). For the five sectors we have picked in the database, two correspond to a general industry group (air transportation and mining) while the three others are subdivided into smaller specific industry groups: four for electricity (hydroelectric power generation, nuclear power generation, electric power generation and diversified electricity), five for oil \& gas (exploration \& development, pipeline, refinery/marketing, diversified oil \& gas) and three for telecommunication (telephone, wireless and services). For the purpose of this study were selected 14 sectors on the basis of the specific industry group. Table 6 shows the distribution of observations across these sectors.

The total number of international transactions is of a comparable size across the general industry groups, with the exception of airline transportation where there are only 918 deals for the last 15 years. With respect to specific industry sectors, Table 6 reports the percentage of deals by SIEs. For instance, international transactions by SIEs in the nuclear power sector represent more than $60 \%$ of the deals over the period. On the contrary, private companies are the main investors in telecommunication services (96.5 percent). This high participation of private companies in the case of telecommunication services is related to the liberalisation of telecom markets over the last decades with price and competition regulations.

Table 6. Distribution of observations by specific industry sectors (1998-2012)

\begin{tabular}{|c|c|c|c|c|c|c|c|c|c|}
\hline \multirow{2}{*}{$\begin{array}{l}\text { General } \\
\text { Industry } \\
\text { Group }\end{array}$} & \multirow[b]{2}{*}{ Specific Industry Group } & \multirow{2}{*}{$\begin{array}{l}\text { Private } \\
\text { deals }\end{array}$} & \multicolumn{5}{|c|}{ SIES } & \multirow[b]{2}{*}{ Total } & \multirow{2}{*}{$\begin{array}{l}\% \text { of } \\
\text { SIES }\end{array}$} \\
\hline & & & Air & $\begin{array}{l}\text { Elec- } \\
\text { tricity }\end{array}$ & $\begin{array}{l}\text { Mi- } \\
\text { ning }\end{array}$ & $\begin{array}{l}\text { Oil \& } \\
\text { Gas }\end{array}$ & $\begin{array}{l}\text { Tele- } \\
\text { com }\end{array}$ & & \\
\hline Airline & Transportation-Airlines & 730 & 188 & - & - & - & - & 918 & 20.5 \\
\hline \multirow[t]{4}{*}{ Electricity } & $\begin{array}{l}\text { Utility \& Energy- } \\
\text { Diversified }\end{array}$ & 1,249 & - & 126 & - & - & - & 1,375 & 9.2 \\
\hline & $\begin{array}{l}\text { Utility \& Energy-Electric } \\
\text { Power }\end{array}$ & 5,102 & - & 824 & - & - & - & 5,926 & 13.9 \\
\hline & $\begin{array}{l}\text { Utility \& Energy- } \\
\text { Hydroelectric Power }\end{array}$ & 127 & - & 32 & - & - & - & 159 & 20.1 \\
\hline & $\begin{array}{l}\text { Utility \& Energy-Nuclear } \\
\text { Power }\end{array}$ & 31 & - & 48 & - & - & - & 79 & 60.8 \\
\hline Mining & Mining-General & 11,897 & - & - & 885 & - & - & 12,782 & 6.9 \\
\hline \multirow[t]{5}{*}{ Oil \& Gas } & Oil \& Gas-Diversified & 1,486 & - & - & - & 387 & - & 1,873 & 20.7 \\
\hline & $\begin{array}{l}\text { Oil \& Gas-Exploration \& } \\
\text { Development }\end{array}$ & 6,677 & - & - & - & 937 & - & 7,614 & 12.3 \\
\hline & Oil \& Gas-Pipeline & 1,152 & - & - & - & 61 & - & 1,213 & 5.0 \\
\hline & $\begin{array}{l}\text { Oil \& Gas- } \\
\text { Refinery/Marketing }\end{array}$ & 892 & - & - & - & 141 & - & 1,033 & 13.7 \\
\hline & Utility \& Energy-Gas & 1,674 & - & - & - & 213 & - & 1,887 & 11.3 \\
\hline \multirow[t]{4}{*}{$\begin{array}{l}\text { Telecommun } \\
\text { ication }\end{array}$} & $\begin{array}{l}\text { Telecommunications- } \\
\text { Services }\end{array}$ & 3,733 & - & - & - & - & 135 & 3,868 & 3.5 \\
\hline & $\begin{array}{l}\text { Telecommunications- } \\
\text { Telephone }\end{array}$ & 4,334 & - & - & - & - & 868 & 5,202 & 16.7 \\
\hline & $\begin{array}{l}\text { Telecommunications- } \\
\text { Wireless/Cellular }\end{array}$ & 1,978 & - & - & - & - & 138 & 2,116 & 6.5 \\
\hline & Total & 41,062 & 188 & 1,030 & 885 & 1,739 & 1,141 & 46,045 & 10.8 \\
\hline
\end{tabular}




\section{c) International transactions}

For each deal, the database provides the information on the nationality of the acquirer, target and divestor. In some cases, there is no information on the divestor, but the acquirer and the target are always indicated. International transactions are the deals where, among the acquirer, the target and the divestor, at least one has a different nationality. All other cases are considered as domestic transactions (with the acquirer, the target and the divestor all sharing the same nationality). When the information on the divestor is missing it has been assumed that it has the same nationality as the target.

For international transactions, there are several types of deals according to the nationality of the acquirer, target and divestor. Based on the difference in the nationality of each, five cases can be identified (see also Figure 5 below):

- Case 1: Domestic deal. The nationalities of the acquirer, target and divestor are the same.

- $\quad$ Case 2: Domestic transaction of foreign asset. The acquirer and divestor have the same nationality but the nationality of the target is different. The target company is located abroad and the deal is concluded in the domestic market.

- Case 3: Change of nationality of investor. In this case, the nationalities of the acquirer, target and divestor are different. This is a cross-border deal between the acquirer and the divestor with a target located in another country.

- $\quad$ Case 4: New investment. The nationality of the target and the divestor is the same but the acquirer has a different nationality. This case is the pure cross-border deal where a domestic asset is acquired by a foreign investor.

- $\quad$ Case 5: Repatriation of asset. The acquirer and the target have the same nationality, but the nationality of the divestor is different. This is a cross-border transaction involving an asset located in the domestic country, i.e. a repatriation of asset. 
Figure 5. Typology of deals

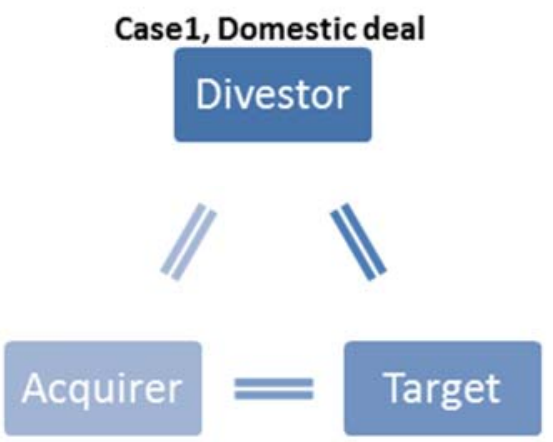

Domestic transaction

International transaction

Case2, Domestic transaction of foreign asset

Case3, Change of nationality of investor

Divestor

I I

Acquirer

=

Target

Case4, New investment

Divestor
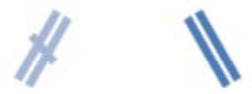

\section{Acquirer}

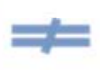

Target

\section{Divestor}

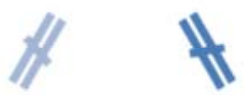

Acquirer

$\underline{=}$

Target
Case5, Repatriation of asset

\section{Divestor}

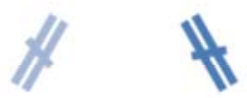

Acquirer

\section{Target}

Source: OECD Secretariat based on Dealogic 
Figure 6 shows the distribution of cross border and domestic deals by SIEs in the five sectors included in the dataset. In the oil \& gas and telecommunication sectors, there are more international transactions than domestic deals. The activity of SIEs in mining is on the contrary rather oriented towards domestic deals. However, the number of deals should be analysed with caution as it does not take into account the deal value, nor the time trend or regions.

Figure 6. Distribution of domestic and international deals by SIEs (1998-2012)

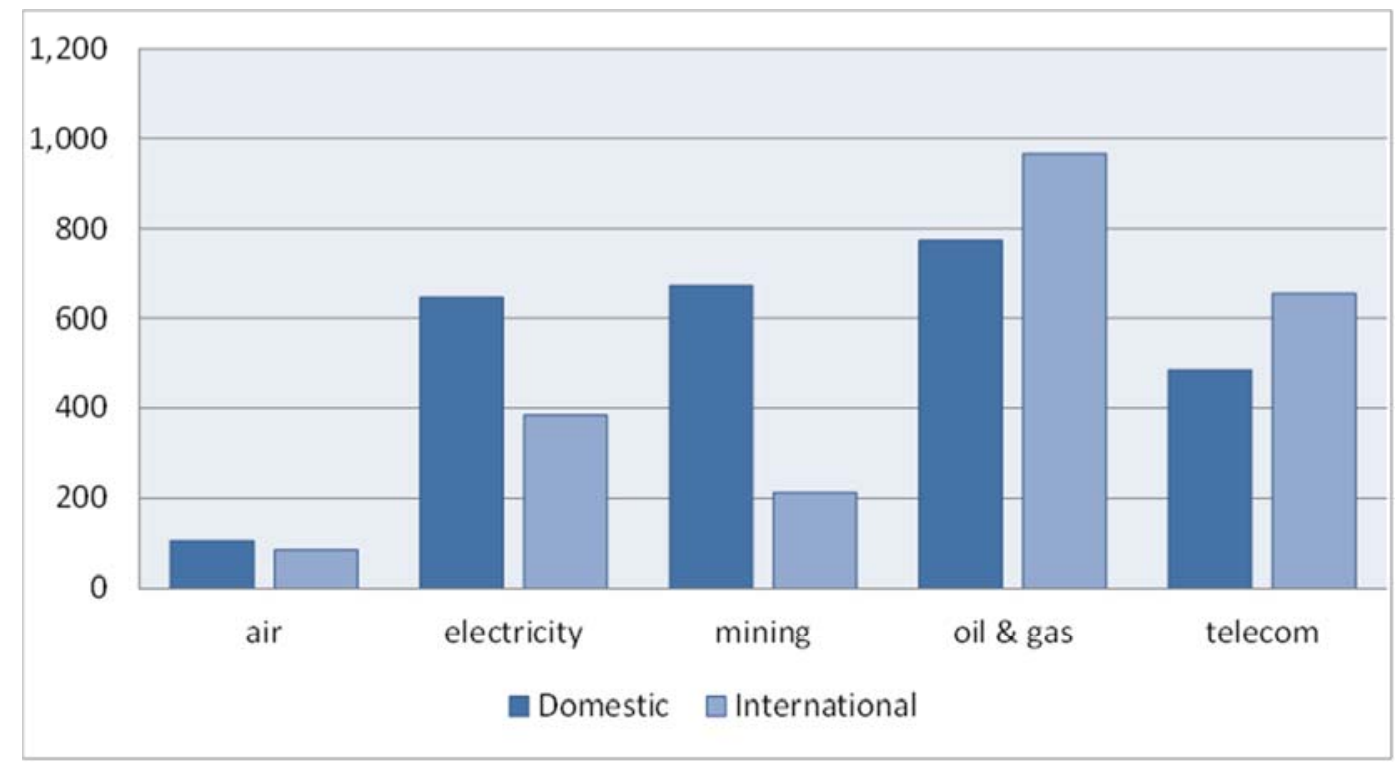

Source: Dealogic

Except the case where the acquirer, target and divestor have the same nationality (domestic deals), all other deals are international transactions and can be classified into one of the 4 cases described above. Table 7 shows the distribution of deals according to these cases and highlights that 61 percent of the deals are domestic. Among international deals, new investments are prevalent (25 percent). Interestingly, the number of international new investments by SIEs in telecommunications is higher than the number of domestic transactions.

Table 7. Distribution of deals by type and by sector (1998-2012)

\begin{tabular}{|c|c|c|c|c|c|c|c|c|}
\hline \multirow{2}{*}{ Type of deals } & \multirow{2}{*}{ Total } & \multirow{2}{*}{ Percent } & \multirow{2}{*}{ Private } & \multicolumn{5}{|c|}{ SIES } \\
\hline & & & & Air & Electricity & Mining & Oil \& Gas & Telecom \\
\hline 1. Domestic deal & 28,221 & 61.3 & 25,539 & 104 & 646 & 672 & 773 & 487 \\
\hline $\begin{array}{l}\text { 2. Domestic transaction of foreign } \\
\text { asset }\end{array}$ & 1,081 & 2.4 & 1,022 & 1 & 19 & 5 & 24 & 10 \\
\hline $\begin{array}{l}\text { 3. Change of nationality of } \\
\text { investor }\end{array}$ & 2,538 & 5.5 & 2,071 & 8 & 80 & 18 & 261 & 100 \\
\hline 4. New investment & 11,723 & 25.5 & 10,245 & 66 & 237 & 141 & 542 & 492 \\
\hline 5. Repatriation of asset & 2,482 & 5.4 & 2,185 & 9 & 48 & 49 & 139 & 52 \\
\hline Total & 46,045 & 100 & 41,062 & 188 & 1,030 & 885 & 1,739 & 1,141 \\
\hline
\end{tabular}

Source: Dealogic and OECD Secretariat 
For those deals where the value of the transaction is known the amounts have been converted to constant 2005 US-dollars using the private final consumption expenditure deflator from the OECD Economic Outlook database. However, as mentioned earlier there are some closed deals without any information on the value. The value is missing for 18,435 deals, representing 40 percent of the total. In the case of the oil \& gas industry, the information is not announced for half of the deals (See table 8, for availability of valuation data for deals).

Table 8. Availability of valuation data for deals (1998-2012)

\begin{tabular}{lccc}
\hline & $\begin{array}{c}\text { Information } \\
\text { available }\end{array}$ & Undisclosed & Total \\
\hline $\begin{array}{l}\text { Non-SIEs } \\
\text { (Private deals) }\end{array}$ & 24,443 & 16,619 & 41,062 \\
\hline Air & 120 & 68 & 188 \\
Electricity & 680 & 350 & 1,030 \\
Mining & 775 & 110 & 885 \\
Oil \& gas & 883 & 856 & 1,739 \\
Telecom & 709 & 432 & 1,141 \\
\hline Total & 27,610 & 18,435 & 46,045 \\
\hline
\end{tabular}

Source: Dealogic

\section{e) Transactions by region}

When taking into account the nationalities reported for the acquirer, target and divestor, there are more than 200 countries involved. Therefore, a regional classification is needed. Four groups of region are used:

- $\quad$ OECD: the 34 OECD members

- Asia: all Asian countries, except Japan, Korea and countries included in FUSSR(see below)

- $\quad$ FUSSR: Former Union of Soviet Socialist Republics, except OECD members

- Others: Other countries including economies from Africa, Latin America, etc.

Table 9 summarises the regional distribution of international transactions for non-SIEs and SIEs in the five sectors selected. The total number of international deals is 17,824 . As it could be expected, intra-regional transactions are much higher than cross-regional transactions. In particular, OECD to OECD deals are by far the most common, but Asia to Asia deals also represent a significant number of deals. Regarding cross-regional transactions, Asia to Other region's international transactions in the oil \& gas industry are quite significant as compared to the other four sectors. This highlights that international transactions from Asia to Africa or Latin America are an important part of Asia's outward investment strategy. 
Table 9. Distribution of international deals by region (1998-2012)

\begin{tabular}{|c|c|c|c|c|c|c|c|}
\hline \multirow{2}{*}{ Direction of flows } & \multirow{2}{*}{ Total } & \multirow{2}{*}{ Private } & \multicolumn{5}{|c|}{ SIES } \\
\hline & & & Air & Electricity & Mining & Oil \& Gas & Telecom \\
\hline Asia to Asia & 1,034 & 761 & 16 & 12 & 47 & 124 & 74 \\
\hline Asia to FUSSR & 38 & 9 & - & - & 10 & 19 & - \\
\hline Asia to OECD & 529 & 301 & 11 & 10 & 104 & 89 & 14 \\
\hline Asia to Others & 193 & 96 & 2 & 1 & 15 & 62 & 17 \\
\hline FUSSR to Asia & 17 & 15 & - & 1 & - & 1 & - \\
\hline FUSSR to FUSSR & 293 & 196 & - & 26 & - & 63 & 8 \\
\hline FUSSR to OECD & 135 & 89 & - & 4 & 1 & 40 & 1 \\
\hline FUSSR to Others & 62 & 41 & - & 2 & - & 19 & - \\
\hline OECD to Asia & 1,299 & 1,189 & 3 & 13 & 1 & 38 & 55 \\
\hline OECD to FUSSR & 573 & 481 & 2 & 15 & - & 33 & 42 \\
\hline OECD to OECD & 9,688 & 8,758 & 34 & 222 & - & 303 & 371 \\
\hline OECD to Others & 2,917 & 2,724 & 5 & 47 & - & 72 & 69 \\
\hline Others to Asia & 40 & 34 & - & - & 4 & 2 & - \\
\hline Others to FUSSR & 20 & 20 & - & - & - & - & - \\
\hline Others to OECD & 316 & 274 & - & 6 & 11 & 25 & - \\
\hline Others to Others & 670 & 535 & 11 & 25 & 20 & 76 & 3 \\
\hline Total & 17,824 & 15,523 & 84 & 384 & 213 & 966 & 654 \\
\hline
\end{tabular}

\section{f) Takeover premiums}

Finally, there is some information on premiums in the Dealogic database. This refers to the premium paid to the target's shareholders based on the closing share price of the target one month before the announcement date of the deal. The data are generally only available for listed companies, but it is worth comparing premiums across sectors and regions, as well as according to the type of deal. Such data are available for 3,378 of the transactions included in the dataset analysed in the present paper. Of these, 398 transactions were undertaken by SIEs.

Figure 7 provides the mean of the premium according to ownership (private versus state-invested enterprises) in international M\&As in each sector. Averages have been weighted according to deal sizes. First of all, private investors pay broadly the same, or slightly higher, takeover premiums compared with SIEs. The only exception is the relatively insignificant (in terms of number of transactions) air transport sector. Conversely, in telecommunications the takeover premiums paid by private international investors is vastly above what is found in the stateinvested sector. However, a closer examination of the data reveals that the private premium is strongly influenced by just two huge cross-border transactions by Vodafone at the beginning of the period.

This is an interesting observation. If SIEs had systematically benefited from concessionary finance - whether in general terms or specifically to fund international takeovers - there would be an expectation that they would overpay relative to private competitors. However, what figure 7 indicates that the case for a "subsidisation argument" is not compelling. Of course this finding may reflect the length of the period under review. It is not inconceivable that a more detailed analysis of the trend in premiums over time, with the regional composition of international M\&A flows changing, would have yielded different results. However, given the percentage of 
transactions for which Dealogic provides takeover premiums (generally between 5\% and 10\% per cent of all) such analysis is not supported by the available data.

Figure 7. Premium in international takeovers by ownership and sector

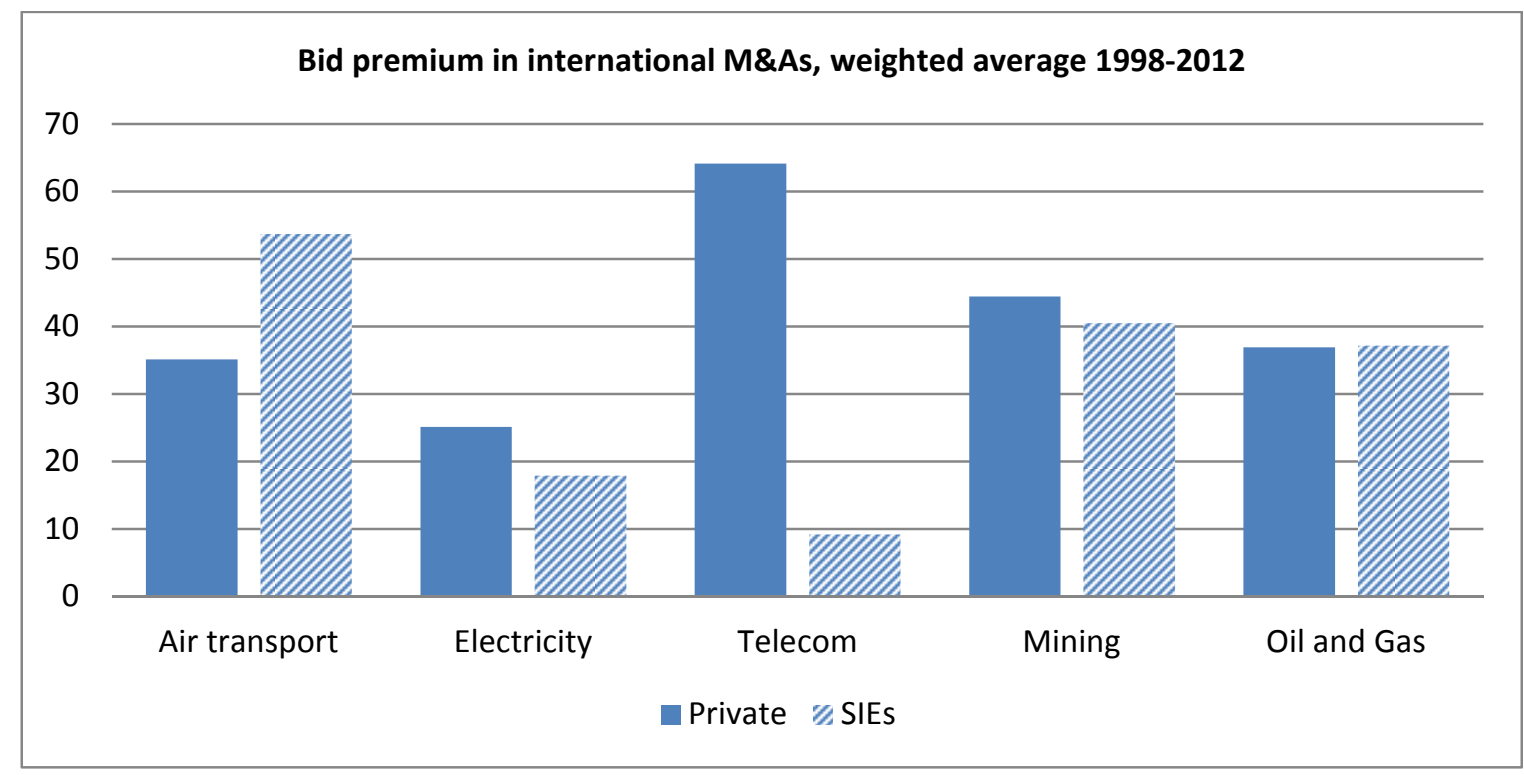

Source: Dealogic and OECD Secretariat

\section{Analysis by sectors}

The previous section indicates that in the world of M\&As (at least in the five sectors under consideration) purely domestic transactions are vastly more important than international M\&As. Moreover, in most sectors privately owned enterprises have been much more active investors than SIEs, and such international M\&As as have been undertaken by SIEs have mostly targeted neighbouring countries rather than the wider global economy. It may seem tempting to conclude that, for these reasons, the concerns about SIE involvement in international investment are overblown. However, this is not a foregone conclusion: important additional questions relate to trends over time - which, if continued over coming decades, could radically change the picture as well as the effects of the appearance of "newcomers" from emerging economies with large remaining SOE sectors in recent years. This section analyses in more depth the time trends as well as national and sectoral composition of M\&A flows.

The shares of international M\&As since 1998 in the five sectors that had an SIE as the investor are shown in Figure 8. The picture is somewhat mixed, but the trends are mostly upwards. With the exception of air transport (where, as mentioned earlier, there are comparatively few international M\&As) the sectors under review have seen the share of SIEs rise since the beginning of the period. In power generation, telecommunication and mining, trends can be detected, whereas SIE share in the oil and gas sector rose sharply around year 2000, but has since then apparently found a plateau. In the mining sector the share of SIEs remains to date (just over $5 \%$ of all transactions) at a comparatively low level. However, as it started from almost zero in 1998 it must nevertheless be concluded that the trend has been significantly increasing. 
Figure 8. Share of international M\&As with a state-invested acquirer

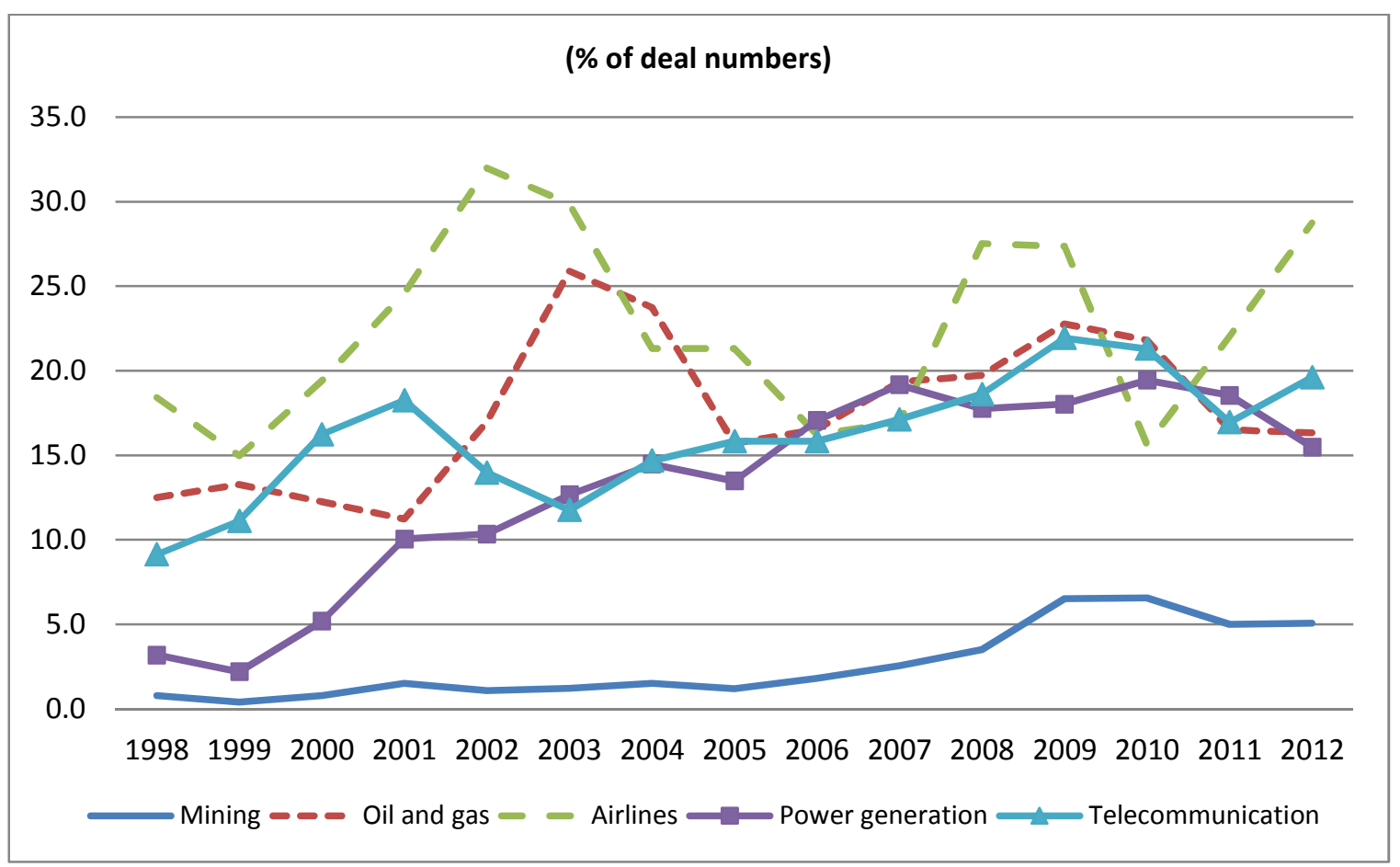

Source: Dealogic and OECD Secretariat

One reason why the relative importance of SIEs may have risen by more than Figure 8 indicates was proposed by OECD (2013b) which notes that the average deal size tends to be larger when SIEs are involved. The dataset prepared for the present study reproduces this finding for three of the five sectors (power generation; oil and gas; mining) where the deal size of SIEs' international M\&As is generally twice the size of comparable private companies. However, this point should not be overstated: as mentioned earlier deal values are available for less than half of all transactions and the lack of information is particularly serious where SIEs are the investors. Possibly, the larger registered deal size may reflect a selection bias where SIEs systematically disclose deal values only where the target is a listed company or otherwise represents a particularly large investment.

\section{a) Oil and gas}

Figure 9 illustrates that the broadly unchanged share of SIEs in international M\&As (around 20\% of total) over the last ten years has taken place amid a sharply increasing number of transactions. A total 225 of international M\&As in 2002 had by 2012 multiplied to 620. Of the latter, 111 transactions has a state-invested enterprise as the bidder. 
Figure 9. International M\&A in the oil and gas sector

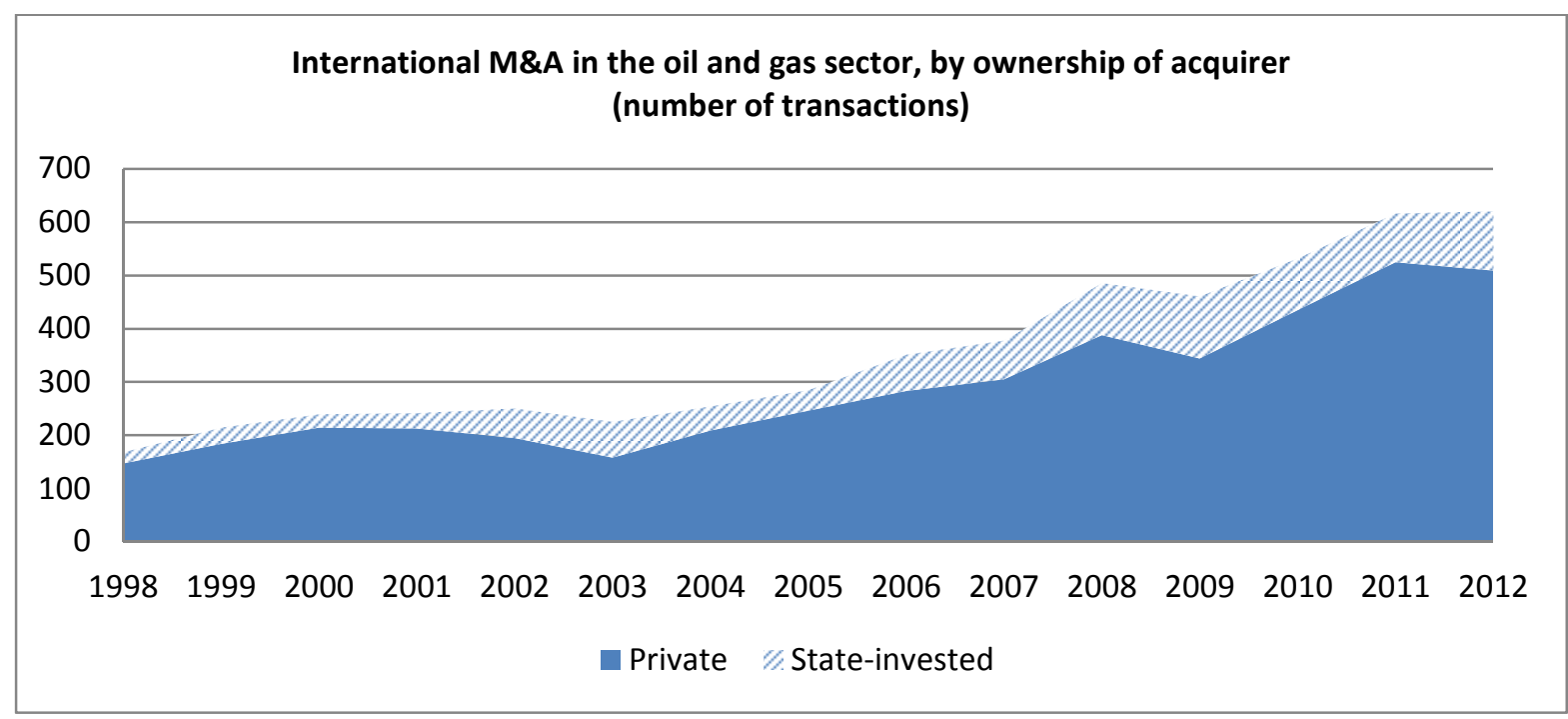

Source: Dealogic and OECD Secretariat

As regards the direction and origins of these transactions, detailed data show that (for the period 1998-2012 as a whole) around 46\% of the international M\&As by SIEs was undertaken by companies domiciled in OECD countries. An additional 30\% came from Asian (non-OECD) economies, and the rest was almost equally distributed among former USSR and other home countries. Again, this does not in itself provide support for concerns about a "takeover" by SIES located outside the OECD area, although a couple of qualifications should be made. First, among the privately owned investors in the oil and gas sector, no less than $82 \%$ were domiciled in the OECD area. The relatively lower share of OECD countries in the SIE category must be taken to indicate that fewer oil and gas companies are state-invested within the OECD area than for example in Asia and the former USSR. Secondly, a much larger share of the OECD-based SIES invested within their own geographic region. Almost $70 \%$ of the international investment originating with SIEs in the OECD area targeted assets located in another OECD country. In the case of Asia the corresponding share was $42 \%$, with an additional $30 \%$ of the investment flowing to OECD economies.

During the period between 1998 and 2012 the change in regional composition of SIE-originated M\&As has been relatively limited. In the early years Asian based SIEs accounted for a relatively low share of $10-20 \%$ of total international M\&As in the sector, but they have since stabilised at around 30\%. Conversely, the OECD countries' SIEs came down from a very high share prior to 2002 , but have since fluctuated around $40-50 \%$ of total outward investment. The former USSR and the "other" category each accounted for around $10-15 \%$ of the international investment by SIEs during the entire period.

The two largest international acquisitions by SIEs in the oil and gas sector were undertaken by OECD-based companies. The two-phased takeover of the British energy group International Power through GDF Suez of France was completed in 2012 (Table 10). According to market analysts at the time the deal, for which the acquirer was estimated to have paid a non-trivial premium, the logic behind the transaction was that it provided GDF Suez with greatly enhanced access to the Latin American and Asian markets. Other large transactions since 2008 included the purchase of the Belgian gas distributor Distrigaz through ENI of Italy. The purchase of 
Canada's Progress Energy Resources by Petronas of Malaysia (which was ultimately approved though first resisted by Canadian investment regulators) was apparently motivated by a wish by the acquirer to secure access to natural gas resources.

Table 10. Top-5 international M\&As undertaken by SIEs in the oil and gas sector between 1998 and 2012 (by value) ${ }^{17}$

\begin{tabular}{cccccc}
\hline Acquirer & $\begin{array}{c}\text { Acquirer } \\
\text { nationality }\end{array}$ & Target & $\begin{array}{c}\text { Target } \\
\text { nationality }\end{array}$ & $\begin{array}{c}\text { Deal value } \\
\text { (US\$ bn) }\end{array}$ & $\begin{array}{c}\text { Date } \\
\text { (announcement) }\end{array}$ \\
\hline GDF-Suez & France & $\begin{array}{c}\text { International } \\
\text { Power plc (32\%) }\end{array}$ & U.K. & 11.1 & March 2012 \\
\hline ENI Spa & Italy & Distrigaz & Belgium & 7.4 & March 2008 \\
\hline Petronas & Malaysia & $\begin{array}{c}\text { Progress Energy } \\
\text { Resources }\end{array}$ & Canada & 5.7 & June 2012 \\
\hline ENI Spa & Italy & LASMO plc & U.K. & 5.0 & December 2000 \\
\hline Statoil & Norway & $\begin{array}{c}\text { Brigham } \\
\text { Exploration }\end{array}$ & U.S. & 4.7 & October 2011 \\
Source: Dealogic & & & & &
\end{tabular}

\section{b) Mining}

Figure 10 illustrates the earlier point that international M\&As in the mining sector has so far been almost totally dominated by private enterprises. In the period between 1998 and 2012, around 5,200 such (private) transactions were recorded, of which 2,071 had acquirers domiciled in Canada, 1,109 in Australia, 559 in the United States and 482 in the United Kingdom. During the same period there were 213 international M\&As by SIEs. Of these, the vast majority came from China (including Hong Kong, China) which recorded 166 such transactions. In second place came Brazil with 35 SIE-engendered deals. In sum, the international transactions in this sector are largely accounted for by private sector enterprises domiciled in a handful of "Anglo-Saxon" economies. Such SIE involvement as there has occurred is accounted for by emerging economies that retain government ownership in their mining sectors.

It follows from the above that the relatively little international $M \& A$ activity that has been undertaken by SIEs has (measured by number of transactions) mostly originated in China and other Asian countries. It was virtually nil until around 2006, following which there was a pickup in takeover activity, which in recent years has accounted for between 25 and 40 transactions per year. Around two thirds of this is accounted for by Asian investment in OECD economies chiefly those Anglo-Saxon economies (above) that have large mining sectors. Around one third of the transactions were undertaken among Asian economies. Independently of this, mining companies in "other" countries (mostly Brazil) have engaged in a steady - but, in terms of deal numbers, relatively low - stream of overseas investments throughout the period.

\footnotetext{
${ }^{17}$ Not including the acquisition by Gazprom OAO of 50\% of the fellow Russian company Sakhalin Energy Investment from a group of international investors.
} 
Figure 10. International M\&A in the mining sector

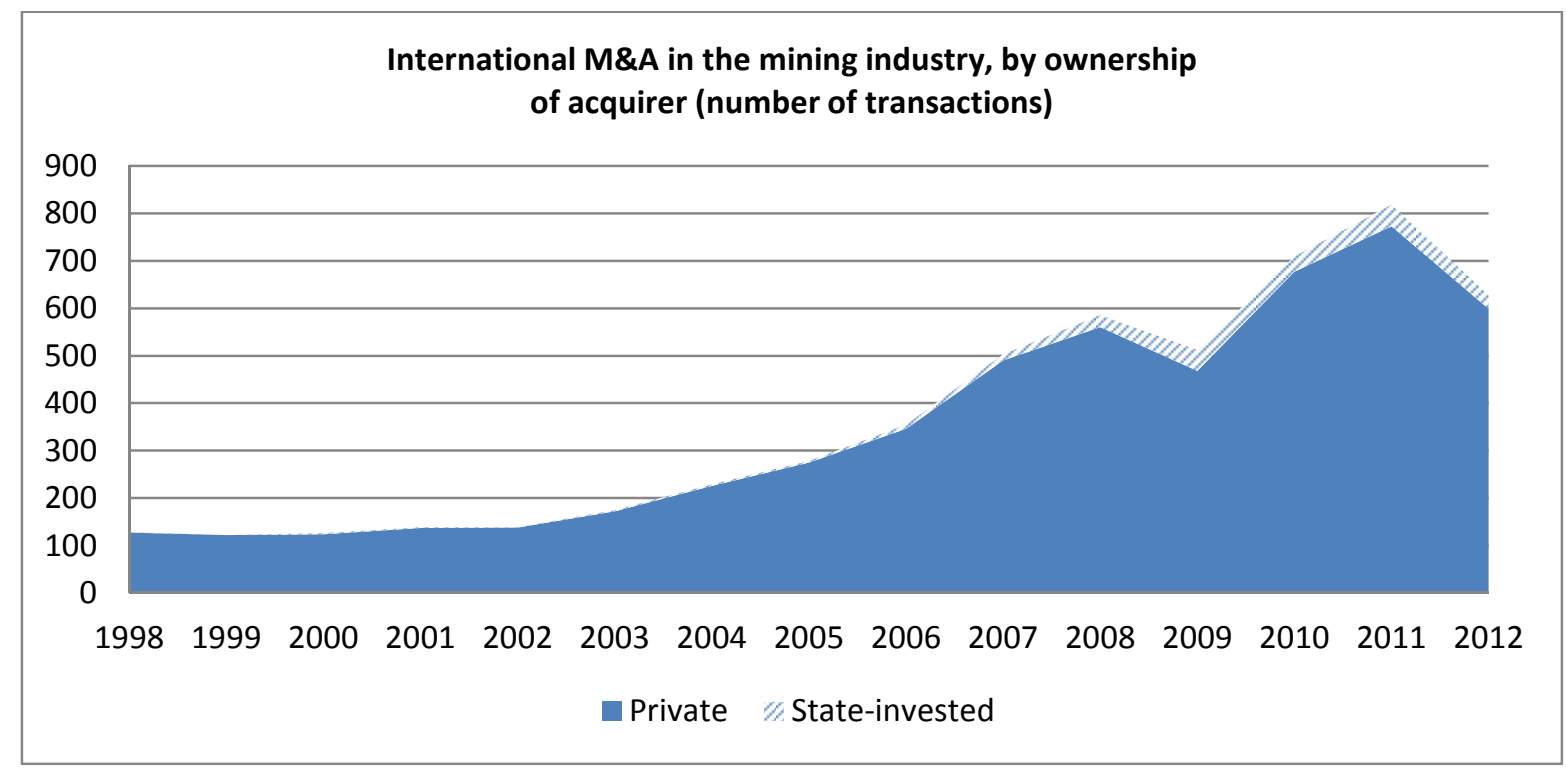

Source: Dealogic and OECD Secretariat

Table 11 illustrates that by far the largest international M\&A (according to Dealogic's valuation data) by an SIE during the period was the all-cash takeover of the Canadian nickel producer Inco by Brazil's Vale do Rio Doce. Other large transactions include the Chinese company's Yangzhou Coal's foray into the Australian coal mining sector (e.g. Felix Resource and Gloucester) reportedly in order to gain access to this strategic resource. The investments by Yangzhou gave rise at the time to some regulatory concerns in Australia, but (as illustrated in Box 2) amid a subsequent weakening of coal prices the authorities' stance appears to have softened somewhat.

Table 11. Top-5 international M\&As undertaken by SIEs in the mining sector between 1998 and 2012 (by value)

\begin{tabular}{cccccc}
\hline Acquirer & $\begin{array}{c}\text { Acquirer } \\
\text { nationality }\end{array}$ & Target & $\begin{array}{l}\text { Target } \\
\text { nationality }\end{array}$ & $\begin{array}{c}\text { Deal value } \\
\text { (US\$ bn) }\end{array}$ & $\begin{array}{c}\text { Date } \\
\text { (announcement) }\end{array}$ \\
\hline $\begin{array}{c}\text { Vale do Rio } \\
\text { Doce }\end{array}$ & Brazil & Inco Ltd. & Canada & 18.7 & August 2006 \\
\hline $\begin{array}{c}\text { Yangzhou Coal } \\
\text { Yangzhou Coal }\end{array}$ & China & Felix Resources & Australia & 2.8 & August 2009 \\
\hline $\begin{array}{c}\text { Vale do Rio } \\
\text { Doce }\end{array}$ & Brazil & $\begin{array}{c}\text { BSG Resources, } \\
\text { Guinea (51\%) }\end{array}$ & Guinea & 2.5 & December 2011 \\
\hline $\begin{array}{c}\text { Jinchuan } \\
\text { Group }\end{array}$ & China & Metorex Ltd. & South Africa & 1.4 & July 2011 \\
\hline
\end{tabular}

Source: Dealogic

\footnotetext{
${ }^{18}$ Not including the acquisition by Gazprom OAO of 50\% of the fellow Russian company Sakhalin Energy Investment from a group of international investors.
} 


\section{Box 2. The expanding presence of Yanzhou Coal in the Australian mining sector}

Yangzhou Coal, a Chinese SOE controlled at the regional level of government and the fourth-largest coal producer in China, has been present in the Australian economy since 2004. It operates through a locally incorporated subsidiary, Yancoal Australia. The company has grown rapidly in terms of market presence, employment and revenue through the ten years to 2013, acquiring six operating coal mines plus several development projects. Mostly, the expansion has taken place through the acquisition of existent Australian mining corporations. The largest two such acquisitions concerned the companies Felix Resources and Gloucester Coal, both of which stock-market listed prior to the takeovers.

The acquisition of Felix Resources in 2009 for $A \$ 3.5$ billion was at the time the biggest-ever Chinese takeover of an Australian company. The largely debt-financed transaction valued the target companies at a premium of around $23 \%$ above its market capitalization. Government regulators placed the condition for the deal that Yancoal must subsequently reduce its share in the company to "below 50\%". In other, smaller mining companies (e.g. Syntech Resources and Premier Coal) Yancoal was required to sell down to $70 \%$.

At end-2011 Yancoal merged with Gloucester Coal. The combined company, retaining the name Yancoal Australia, became listed in the stock exchange in 2012 with the previous owners of Gloucester retaining $23 \%$ of the combined company. Yanzhou is estimated to have paid A\$2.1 billion for the deal, which values Gloucester shares at around $45 \%$ above their closing price. The bid premium was considered as high at the time of the deal, but attributed by market analysts to the fact that Gloucester, in addition to its coal assets, also disposed over strategically important port facilities. Australian regulators made the deal conditional on the Chinese parent company gradually reducing its ownership in Yancoal to less than 70\%.

As of late 2013 the value of the combined company, mostly reflecting a steady decline in the international price of coal, had been reduced by almost half (from $A \$ 1.3$ billion at the time of the merger to around $A \$ 0.7$ billion). Moreover, the company's shares were traded well below book equity value - a fact attributed by equity analysts to concerns about an extraordinarily high debt-equity ratio.

In December 2013 the Australian Treasury eased certain of the foreign investment conditions that had been placed on the company. An option was put on the table to let Yancoal diverge, subject to prior Treasury approval, from the agreed reductions in ownership shares insofar as operating conditions are affected by changes in economic conditions and other factors. The Australian Treasurer informed the public that Yanzhou Coal had provided commitments to continue to support ongoing operations in Australia and maintaining its position as a major regional employer. He was cited as saying that "so long as Yanzhou continues to own at least 51\% of the shares of Yancoal, Yanzhou will ensure Yancoal continues to operate so that it remains solvent".

Sources: KPMG and various issues of Wall Street Journal and The Australian

An illustration of the recurrent allegation that state-owned mining companies may - whether for public policy reasons, or because of access to concessionary financing - are sometimes overpaying may arguably have been provided when the Chinese Jinchuan Group took the South African metal miner Metorex private in 2011. The agreed price of ZAR 8.90 per share was described by market analysts as very generous; the highest rival bid at the time was reportedly ZAR 7.35 per share.

\section{c) Air transport}

As already mentioned, air transport is the only one of the sectors under review where international M\&As are relatively rare. This applies equally to private companies and SIEs, and reflects that fact that airlines tend to conduct international transactions through arms-length trade or via branches and small-size subsidiaries. Figure 11 shows that number of deals has generally fluctuated between 15 and 30 per year, 5-10 of which accounted for by SIEs. Such cross-border M\&As as have taken place relate mostly to takeovers of ailing rivals and the acquisition of companies in related industries as part of vertical or horizontal diversification strategies. 
Figure 11. International M\&A in the air transport sector

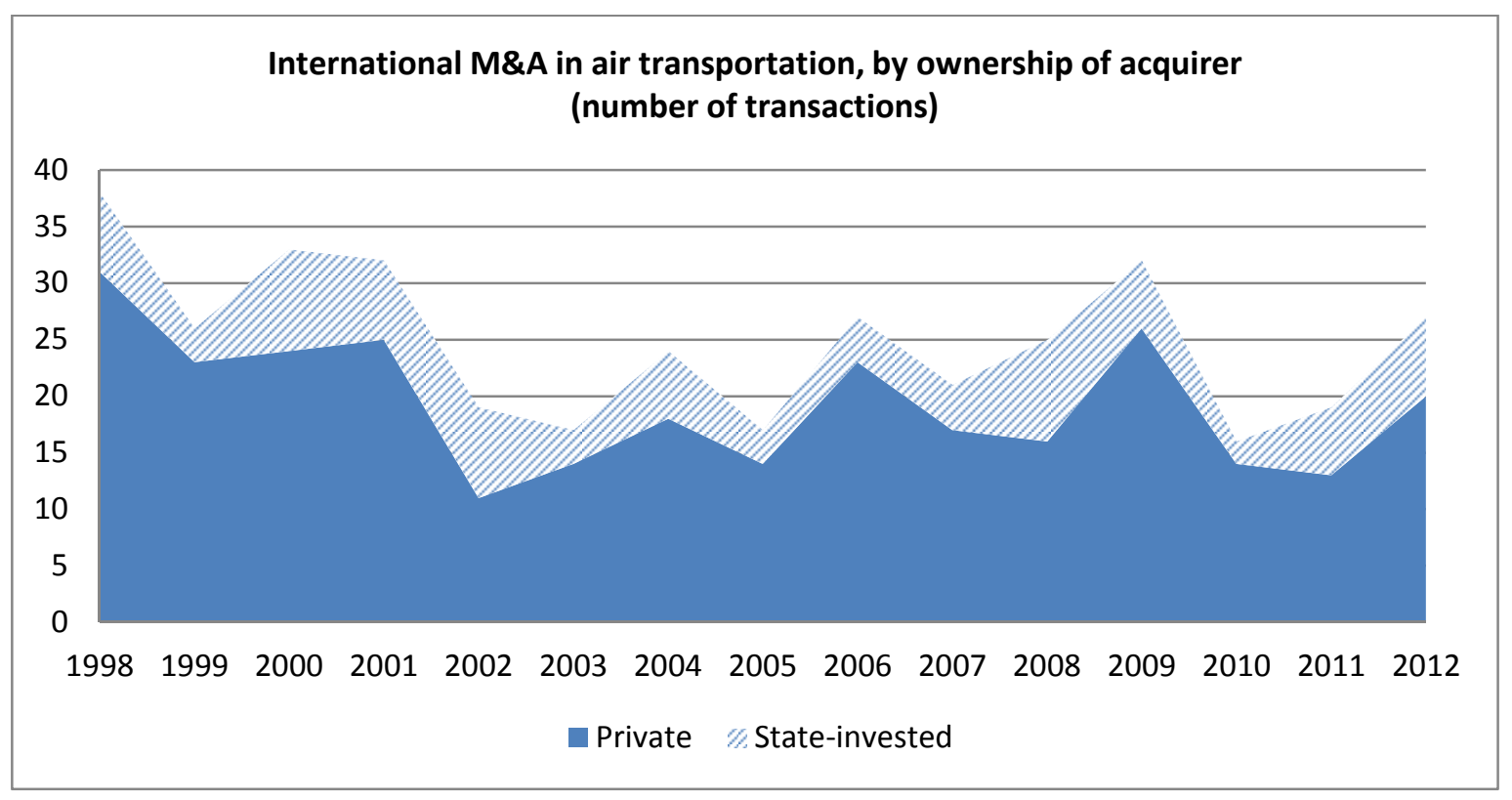

Source: Dealogic and OECD Secretariat

In a limited sample of only 84 international M\&As by SIEs it is possible to follow the investment patterns of individual companies. For example, almost half of all transactions were affected between OECD countries. This mainly reflects three factors: (1) the Air France/KLM merger and subsequent investments by the combined group; (2) takeovers of a number of small regional airlines by Scandinavian Airlines in the first half of the period; and (3) investments by Air New Zealand in Australia. Outside the OECD area there have been a number of international M\&As by Chinese airlines, mainly within the Asian region, and by Singapore Airlines and companies located at the Persian Gulf in a mixture of OECD and non-OECD economies.

As shown by Table 12 the value of transactions in this sector (where the necessary data is available) tends to be smaller than what is seen elsewhere. To some extent this is due to the fact that many investments - reflecting international rules on the ownership of flag carriers - take the form of minority stakes, but it is also related to widespread recent troubles with profitability in this sector which has led to generally low market valuations. Considering the latter, it may be surprising that not more international consolidation has taken place, but a number of governments continue to perceive their national airlines as strategic assets and/or as the upholders of the national capitals as international air transport hubs. Where consolidations of loss-making airlines through a strategic outside investor have taken case (with the notable exception of Air France-KLM) the acquirer has usually been a private company. One example of the latter has been the German Lufthansa's expansion on the European continent during the period under consideration. 
Table 12. Top-5 international M\&As undertaken by SIEs in the air transport sector between 1998 and 2012 (by value) ${ }^{19}$

\begin{tabular}{cccccc}
\hline Acquirer & $\begin{array}{c}\text { Acquirer } \\
\text { nationality }\end{array}$ & Target & $\begin{array}{c}\text { Target } \\
\text { nationality }\end{array}$ & $\begin{array}{c}\text { Deal value } \\
\text { (US\$ bn) }\end{array}$ & $\begin{array}{c}\text { Date } \\
\text { (announcement) }\end{array}$ \\
\hline Air France SA & France & $\begin{array}{c}\text { KLM Royal Dutch } \\
(89 \%)\end{array}$ & Netherlands & 5.0 & September 2003 \\
\hline $\begin{array}{c}\text { Singapore } \\
\text { Airlines }\end{array}$ & Singapore & $\begin{array}{c}\text { Virgin Atlantic } \\
(49 \%)\end{array}$ & U.K. & 1.0 & December 1999 \\
\hline Air China & China & $\begin{array}{c}\text { Cathay Pacific } \\
(12.5 \%)\end{array}$ & $\begin{array}{c}\text { Hong Kong, } \\
\text { China }\end{array}$ & 0.8 & August 2009 \\
\hline $\begin{array}{c}\text { Air France- } \\
\text { KLM }\end{array}$ & France & $\begin{array}{c}\text { Alitalia (25\%) } \\
\text { Italy }\end{array}$ & 0.4 & January 2009 \\
\hline $\begin{array}{c}\text { Air New } \\
\text { Zealand }\end{array}$ & $\begin{array}{c}\text { New } \\
\text { Zealand }\end{array}$ & $\begin{array}{c}\text { Ansett Australia } \\
(50 \%)\end{array}$ & Australia & 0.4 & February 2000 \\
\hline $\begin{array}{c}\text { Source: Dealogic } \\
\text { (U) }\end{array}$ & & & &
\end{tabular}

\section{d) Telecommunication}

International M\&A activities in the telecommunications sector have been somewhat untypical in the sense that they peaked (both in terms of numbers as illustrated in Figure 12 and, apparently, in value terms) in the beginning of the period and have receded ever since. Of course this mostly reflects the takeovers and consolidation during the "dot-com bubble" leading up to year 2000. However, as far as SIEs are concerned a secondary reason may have been the ongoing effect of the liberalisation of the utilities sectors in a number of European economies, since many of the concerned economies had state-owned incumbents in the telecom sector. As noted earlier, the share of SIEs in total international M\&As has increased somewhat toward the end of the period under review, so this is apparently one of the sectors where the role of the state is trending upwards. However, as indicated in a related context by OECD (2013b), this largely reflects an unchanged level of activity among the SIEs since the onset of the current financial crisis (they have constantly accounted for 40-50 international M\&As per year) whereas takeovers by the private sector have receded amid the weakening economy. There is no indication of transaction size in state-controlled takeovers having being larger in the period since 1998, and indeed during the dot-com boom the record-hitting deals were mostly found within the private sector.

International M\&As in telecommunications display a strong intra-regional bias, with most transactions taking place among countries that are either geographically close or at an equal level of economic development. Moreover, most activity has taken place within the OECD area. In every year since 1998 did SIEs based in the OECD area account for at least 70\% of international SIE-engendered M\&As - though it must be admitted that the share has declined somewhat during the period. Mostly this has reflected North European state-owned companies buying into the telecommunication sectors of either neighbouring or post-transition economies (plus, during the crisis, to some extent South European countries as well). The early period as well as the last few years moreover saw a number of foreign takeovers by Japan's NTT. Outside the OECD area the SIEs active in international M\&As have largely been located in eastern Asia and the Persian Gulf countries. The targets have, with a few exceptions, been located in the same two regions plus South Asia.

\footnotetext{
${ }^{19}$ Not including the acquisition by Gazprom OAO of $50 \%$ of the fellow Russian company Sakhalin Energy Investment from a group of international investors.
} 
Figure 12. International M\&A in the telecom sector

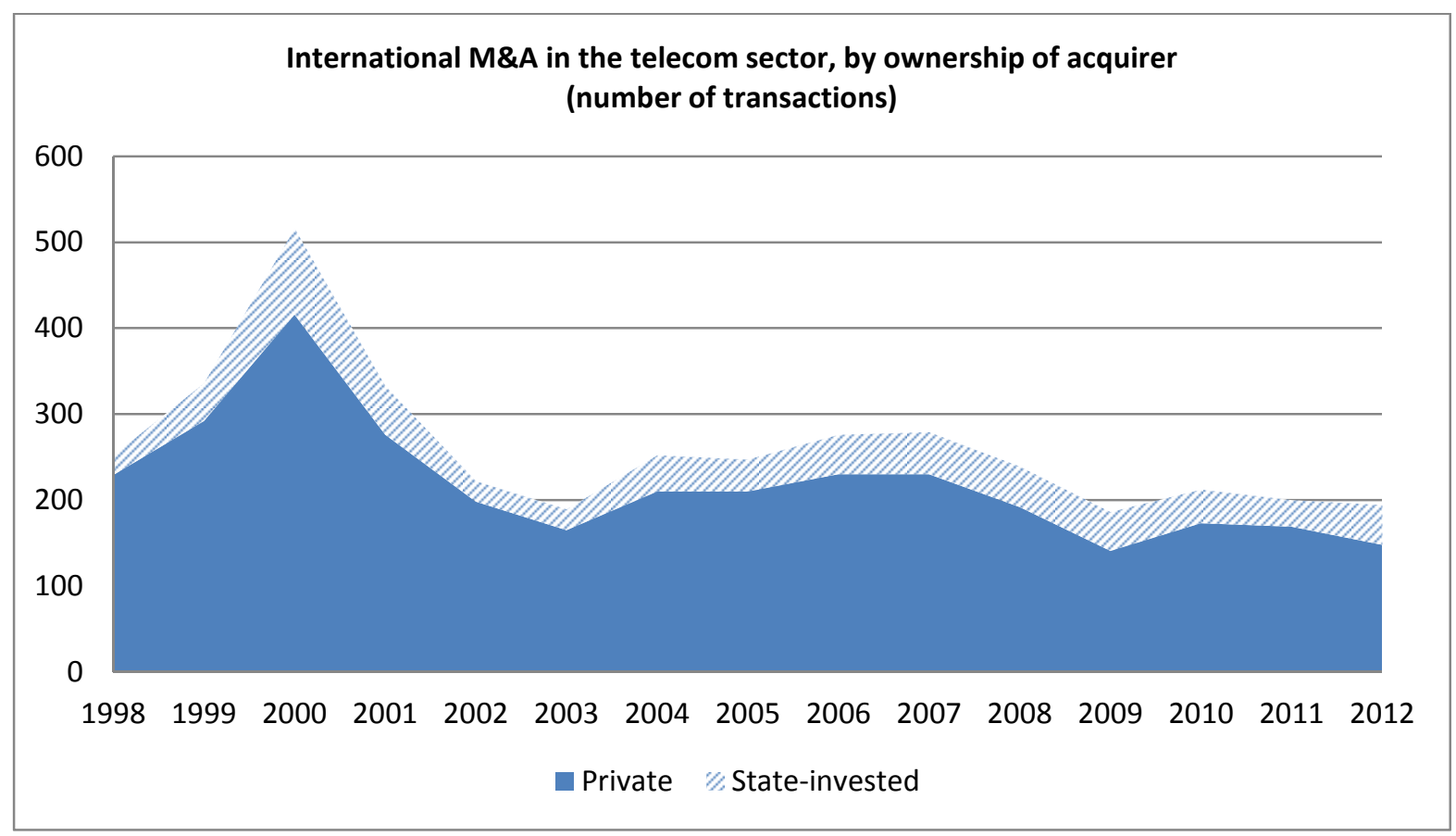

Source: Dealogic and OECD Secretariat

Reflecting the previous observations, all top-5 international M\&As undertaken by SIEs since 1998 (in value terms) were found in large OECD economies: France, Germany and Japan (Table 13). By far the largest were the takeovers of Orange (of the U.K.) by France Telecom and VoiceStream Wireless (of the U.S.) by Deutsche Telekom. If any common trend can be derived by the table it may be that (1) most of the largest transactions took place during the dot-com bubble; and (2) the targets were mostly located in economies with widely dispersed shareownership and a mostly relaxed regulatory approach to inward investment. The spirit of those days can perhaps be epitomised through the fact that, for example, France Télecom also bought stakes in several other international firms (GlobalOne, Equant, Internet Telecom, Freeserve, EresMas, NTL, Mobilcom) some of which have since been sold back. 
Table 13. Top-5 international M\&As undertaken by SIEs in the telecom sector between 1998 and 2012 (by value) $^{20}$

\begin{tabular}{|c|c|c|c|c|c|}
\hline Acquirer & $\begin{array}{c}\text { Acquirer } \\
\text { nationality }\end{array}$ & Target & $\begin{array}{c}\text { Target } \\
\text { nationality }\end{array}$ & $\begin{array}{c}\text { Deal value } \\
\text { (US\$ bn) }\end{array}$ & $\begin{array}{c}\text { Date } \\
\text { (announcement) }\end{array}$ \\
\hline France Telecom & France & Orange plc & U.K. & 46.3 & May 2000 \\
\hline $\begin{array}{l}\text { Deutsche } \\
\text { Telekom }\end{array}$ & Germany & $\begin{array}{c}\text { VoiceStream } \\
\text { Wireless } \\
\end{array}$ & U.S. & 34.6 & July 2000 \\
\hline $\begin{array}{l}\text { Deutsche } \\
\text { Telekom }\end{array}$ & Germany & One 2 One & U.K. & 13.6 & August-1999 \\
\hline France Telecom & France & $\begin{array}{c}\text { Retevision Movil } \\
(80 \%)\end{array}$ & Spain & 10.8 & July 2005 \\
\hline $\begin{array}{c}\text { Nippon } \\
\text { Telegraph \& } \\
\text { Telephone }\end{array}$ & Japan & $\begin{array}{l}\text { AT\&T Wireless } \\
\text { Group (16\%) }\end{array}$ & U.S. & 9.8 & November 2000 \\
\hline
\end{tabular}

\section{e) Electricity}

The growing share of SIEs in international M\&As in the electricity (power generation and integrated producers) sector reflects an actual increase in the number of transactions (See figure 13). From virtually zero in the beginning of the period they have grown to around 40 deals per year. As was the case with the telecom sector, the bulk of these transactions originated with SIEs located within the OECD area (more than two thirds of total in all years). And, with the exception of a few takeovers of electricity producers located in the former USSR and other post-transition economies, the transactions largely targeted other OECD countries. The largest number of transactions took place among European countries and seemed to be connected to a crossborder consolidation of the sector - perhaps triggered by the increasingly integrated European energy markets.

Outside the OECD area there were signs of a similar cross-consolidation of electricity sectors within Latin America and the former USSR - with acquirers located in Colombia and Russia, respectively, in the driving seat. In the Asian continent international M\&A activity has rather sedate. The most active players (both within the region and in OECD countries) have been power generators located in the Persian Gulf states, notably the U.A.E. Overall, in Asia, Latin America and the former USSR no particular trend - neither upward nor downward - can be detected in international M\&As by SIEs over the last decade.

When addressing individual transactions during the period, two international M\&As by SIEs stand out (Table 14). ENEL of Italy acquired $71 \%$ of Spanish Endesa for an estimated US\$ 52.6 billion in two staggered transactions in 2007 and 2009 - which, in combination with earlier investments, brought its ownership stake above 92\%. This investment is illustrative of a couple of the issues that are commonly discussed in the context of SIE investment. First, ENEL achieved the takeover after a contest with E.On of Germany, which makes it a case of a state-invested enterprise outbidding a private one. Secondly, there were significant "national" concerns in Spain about the incumbent electricity provider being taken over by a foreign company, as well as political embarrassment when a rival bid by a Spanish utility company was turned down on anti-trust grounds. One of the factors contributing to ENEL's success may have been the fact that it bid jointly with a Spanish company - which it subsequently bought out.

\footnotetext{
${ }^{20}$ Not including the acquisition by Gazprom OAO of $50 \%$ of the fellow Russian company Sakhalin Energy Investment from a group of international investors.
} 


\section{Box 3. The acquisition of British Energy by EDF}

In January 2009, completing what was one of the largest-ever cross-border takeovers in the energy sector, the state-owned French company Électricité de France (EDF) obtained 100\% ownership of British Energy. British Energy was at the time the largest power generation company in the United Kingdom and the country's sole operator of nuclear power stations. The deal, valued at US\$23.1 billion, involved the sale of a large minority shareholding by the UK government as well as a number of smaller stakes by institutional and other investors. Following the transaction, The proceeds were reportedly $10 \%$ above the valuation estimates presented to the government by the UK Shareholder Executive. EDF subsequently sold a $20 \%$ stake in the company to the private British utilities group Centrica in a deal which also saw EDF acquire majority control of the Belgian electricity company SPE.

The background to the transaction was the following. British Energy had been state-owned until its privatisation through a stock market flotation in 1996. The Government obtained a financial interest in the business once again in 2005 after helping British Energy achieve a solvent restructuring, following a sustained deterioration in its financial position. The Government agreed to provide assistance because the Company was of national strategic importance. British Energy agreed to make annual payments to the Nuclear Liabilities Fund of 65 per cent of the Company's available free cash flow as a condition of the restructuring. The Nuclear Liabilities Fund, which is responsible for the future cost of decommissioning British Energy's existing fleet of nuclear power stations, was directed by the Government to exercise its right to convert part of this entitlement into shares in June 2007 when it reduced its interest from 65 per cent to 36 per cent in a sale to institutional investors, raising $£ 2.3$ billion.

The impetus for the sale came from British Energy, which wanted to play a part in new nuclear build but was unable to raise investment funds because of its financial record, the poor performance of some of its reactors, and its lack of experience of building new reactors. The board saw operating British Energy solely as a run-down agency for its eight existing nuclear power stations as commercially unsustainable. However, the Government would have barred British Energy from building new nuclear power stations as long as it retained an interest in the Company as the Government did not want to expose taxpayers to nuclear investment risk.

EDF declared at the time of the acquisition that it intends to build four nuclear reactors on the land acquired through its purchase of British Energy, and that it is aiming to build the reactors by 2025, with the first operational by 2017. The UK Government concluded on the basis of discussions with EDF that EDF had a credible programme to deliver the new reactors. It also publicly recognised that the construction of these new stations was not a foregone conclusion. It would depend on a range of factors, including future prices of fossil fuels, obtaining the requisite planning permits, and EDF's own evolving corporate strategies.

In October 2013 a deal was struck between the UK government, EDF and two Chinese partners - the state-owned China National Nuclear Corporation and China General Nuclear Power Corporation - the ensure the construction of the first nuclear power plant. As part of the agreement the UK government will allow the Chinese companies to act as investors (initially minority-stake owners) in British nuclear power stations in partnership with EDF. To ensure the profitability of the investment, EDF is guaranteed a wholesale electricity price for the first 35 years of operation which is twice the current rate. The public purse will subsidise the difference, the subsidy being justified as a means of converting the country's energy mix to low-carbon sources.

Source: UK National Audit Office and various press articles.

An equally illustrative transaction was the takeover by Electricite de France (EDF) of the likewise state-owned company British Energy for US\$23 billion in 2008. The deal surprised some at the time because it effectively implied the transfer of the entire UK nuclear energy generation to French government control. However, the transaction was apparently motivated largely by fiscal and commercial concerns, such as a lack of adequate technological knowhow and domestic public funding to finance a renovation and expansion of British Energy's generation capacity (Box 3). 
Figure 13. International M\&A in the electricity sector

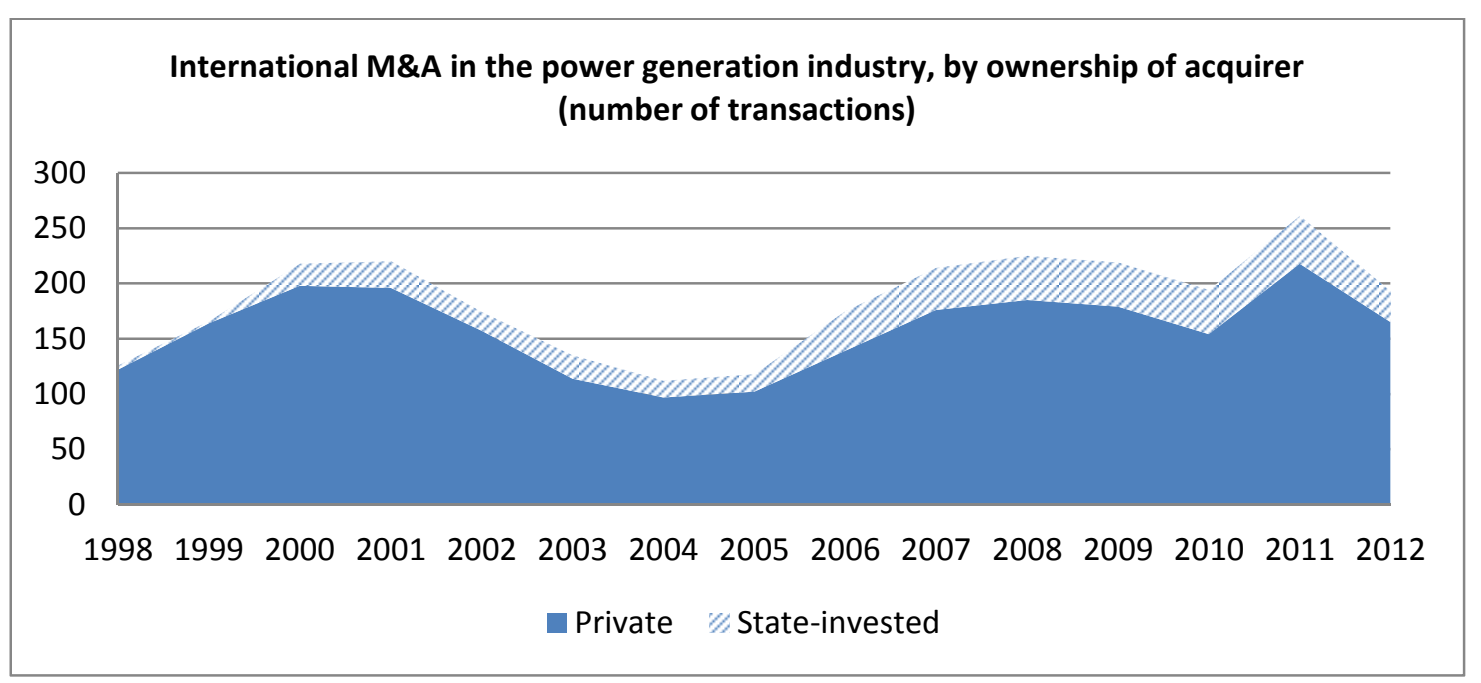

Source: Dealogic and OECD Secretariat

Subsequent controversy arose when EDF brought on board two Chinese state-owned companies as minority partners in the project. Far from opposing this move, the UK government negotiated a minimum wholesale price on electricity with EDF to guarantee the future financial viability of the project. This could arguably serve as an illustration of a more wide-ranging issue: host country governments - whether in developing countries or mature economies - are often grateful for investment by foreign state-owned enterprises, especially when offered on concessionary terms. The "losers" (if any) tend to be competing private enterprises, and if no one such is domiciled in the host economy then the "level playing field" argument tends to receive little political attention.

Table 14. Top-5 international M\&As undertaken by SIEs in the power generation sector between 1998 and 2012 (by value) $^{21}$

\begin{tabular}{|c|c|c|c|c|c|}
\hline Acquirer & $\begin{array}{c}\text { Acquirer } \\
\text { nationality }\end{array}$ & Target & $\begin{array}{c}\text { Target } \\
\text { nationality }\end{array}$ & $\begin{array}{l}\text { Deal value } \\
\text { (US\$ bn) }\end{array}$ & $\begin{array}{c}\text { Date } \\
\text { (announcement) }\end{array}$ \\
\hline ENEL SpA; & Italy & Endesa $(71 \%)^{22}$ & Spain & 52.6 & $2007 / 2009$ \\
\hline $\begin{array}{l}\text { Electricité de } \\
\text { France }\end{array}$ & France & British Energy & U.K. & 23.1 & September 2008 \\
\hline $\begin{array}{c}\text { Electricité de } \\
\text { France }\end{array}$ & France & Edison SpA (30\%) & Italy & 6.4 & December 2011 \\
\hline $\begin{array}{c}\text { Abu Dhabi } \\
\text { National } \\
\text { Energy }\end{array}$ & U.A.E. & $\begin{array}{c}\text { PrimeWest } \\
\text { Energy }\end{array}$ & Canada & 4.6 & September 2007 \\
\hline $\begin{array}{l}\text { Electricité de } \\
\text { France }\end{array}$ & France & $\begin{array}{c}\text { Constallation } \\
\text { Energy Group } \\
(49.9 \%)\end{array}$ & U.S. & 4.5 & December 2008 \\
\hline
\end{tabular}

\footnotetext{
${ }^{21}$ Not including the acquisition by Gazprom OAO of $50 \%$ of the fellow Russian company Sakhalin Energy Investment from a group of international investors.

${ }^{22}$ ENEL has gradually built up a stake of $92 \%$ of the voting shares of Endesa. The largest single transaction saw the acquirer buy $71 \%$ of the stock jointly with the Spanish Acciona (in 2007) and subsequently (in 2009) buy out its partner's shares.
} 


\section{CONCLUSIONS AND MAIN FINDINGS}

A growing role for the state in the marketplace. State-owned and state-invested enterprises have become more prominent in the global economy over the last decade. This mostly reflects the growing importance of merging economies where the state continues to play a dominant role in the commercial economy - but it is also related to a continued ownership of sizeable minority stakes in listed enterprises in a number of OECD countries. The trend toward a growing role for SOEs is likely to continue in the short and medium-term future. Most medium-term projections foresee significantly higher growth rates in those economies that have many SOEs than the more mature economies, and while some of these have embarked on privatisation programmes the macroeconomic growth has generally outpaced the divestments.

Adherence to best practices would defuse concerns - but most countries are "not there yet". A growing role for state-invested enterprises in the marketplace is not in itself onerous. According to an OECD consensus, as expressed through the Organisation's legal instruments, SOEs can be operated according to similarly high standards of governance, transparency and efficiency as private companies, in which case the ownership issue is moot. The fact that SOEs are commonly charged with pursuing certain non-commercial priorities needs not be a problem either, provided these priorities are disclosed and their costs compensated (without being overcompensated). However, it would appear that only some of the world's most advanced economies, following decades of reform of their SOE sectors, have approached this point. Many other countries still have a long way to go, and in the interim their state-owned enterprises could be a source of economic inefficiencies and/or market distortions.

Cross-border operations may compound the concerns. When SOEs operate across borders the challenges may multiply. For example, governments may decide to maintain companies that have significant monopolies in their domestic economy in State ownership purely on efficiency grounds. However, if they expand into the competitive economies of other countries the challenge of maintaining a "level playing field" can become extremely complex. Also, SOEs may be charged with non-commercial priorities that are in the interest of, and commonly accepted by, the general public in their home country - yet perceived as onerous in foreign jurisdictions.

An overall commitment to competitive neutrality? One way of addressing these challenges proposed by OECD is a widespread commitment to a competitive neutrality framework for companies engaged in international commerce. Such a framework would ensure that no company, purely in consequence of its ownership, is at a competitive advantage or disadvantage in the marketplace. Some countries have implemented elements of this in their domestic legislation and regulation. A more widespread international understanding of the domestic and cross-border importance of maintaining a level playing field may be within reach. However, an broader multilateral, extra-territorially enforceable commitment to competitive neutrality still appears to be a remote prospect.

Specific action aimed at levelling some aspects of the playing field. In the absence of a portmanteau undertaking towards competitive neutrality, some of the most frequently-cited departures from competitive neutrality might be addressed through targeted action. One such area might be the conditions on which SOEs obtain their funding and financing. Explicit or implicit government guarantees continue to allow many SOEs to operate with more leverage and obtain cheaper loans (including from purely commercial lenders) than private enterprises in like circumstances. Numerous investment and trade agreements also address the issue of state- 
owned enterprises operating across borders, as do some recent changes in national investment regulation.

There are some indications that state-invested firms enjoy competitive advantages. The empirical analysis presented in this paper indicates that, in addition to any financing advantages, large state-invested enterprises also seem to benefit from an unusually high degree of market dominance in their home countries. A comparative analysis of five sectors where state ownership is prevalent shows that, in the course of the last ten years, SIEs have generally enjoyed higher rates of return than comparable private companies. This may be partly related to the aforementioned easier access to financing, but the empirical evidence of this is inconclusive. Far more compelling evidence points to comparatively high profit margins and mark-ups in the state-controlled enterprises. Among anti-trust practitioners this is usually taken as an indication of a high degree of market concentration - perhaps in combination with other, unspecified advantages for the SIEs.

SOEs are becoming more "international", but not necessarily more "political". The actual internationalisation of state-invested enterprises has continued apace, mostly because many of them are located in sectors where cross-border transactions are the commercial norm. However, contrary to what is sometimes alleged in public debate, with a few exceptions there is little evidence that state-owned enterprises have been actively encouraged to go abroad for "political" reasons. A certain rise in the share of SIEs in cross-border mergers and acquisitions has been seen over the last 1-2 decades, but in most sectors the SIEs are still dwarfed by private investors, and purely domestic transactions continue to outstrip international M\&As by a wide margin.

Contributing factors have been intra-EU consolidation and Asian outward investment. At the sectoral level, an increase in state-driven cross-border investment in some of the public utilities sectors is acknowledged, relating to a large extent to intra-OECD takeovers engendered by companies that are part-owned by the governments of European countries. One sector in which a growing SIE involvement is attributed to companies located in emerging economies is the mining industry. Here, SIEs have grown from almost an almost zero share prior to the $21^{\text {st }}$ century - a development driven largely by Chinese and other Asian companies. True, at 5-6\% of total international M\&As the SIEs still have an internationally low share, with the bulk of transactions still attributed to private mining companies domiciled in a handful of Anglo-Saxon countries. However, if current trends continue in the future state-controlled mining companies operating from emerging economies are set to become an important international factor.

Host countries have often welcomed the contribution from foreign state-owned investors. Based on evidence from some of the largest individual transactions it would appear that concerns about a level international playing field goes beyond the actions of SOE owners. In many cases the host country authorities have actively welcomed the inward investment by foreign SOEs, hailing them as a source of funding or knowhow that were not available locally. Again, insofar as the foreign SOEs are operating according to normal commercial criteria this is a win-win situation. However, if they enjoy unfair advantages then the losers will be the private competitors - a fact to which host country authorities may or may not be sensitive according to where the private competition is domiciled. In other words, the commitment to uphold basic principles of competitive neutrality on the part of host governments may in practice depend on whether there is a significant domestic production in the sector concerned.

Given the lingering doubts a more structured international approach may be called for. Summing up, the growing role of state-invested enterprises in the international marketplace does not yet present a serious macroeconomic challenge. However, since it is likely to keep growing in 
the coming decade, some challenges need to be addressed relatively soon. Mostly, these relate to the benefits that SIEs seem to derive from privileged access to finance and, often, a dominant position in their home markets. The evidence reviewed in the previous sections of advantages to state-invested has been mixed - but precisely because it is mixed a number of doubts and concerns linger. Going forward, this creates a strong case for enhanced policy coordination and information sharing.

OECD is well placed to take the lead. The OECD could take the lead. If legally binding instruments cannot be developed in the near to medium-term to ensure competitive neutrality, a consultation mechanism could be established through which the main players in international trade and investment can regularly exchange views on matters of common concern related to the state in the marketplace. Through information gathering and the creation of an informal "contact point" such a mechanism could be instrumental in defusing disagreements and prevent the advent of state-invested enterprises from spurring a protectionist backlash. The ultimate purpose would be ensuring that the international trade and investment environment remains open, nondiscriminatory and offering a level playing field. 


\section{REFERENCES}

Capobianco, A. and H. Christiansen (2011), "The Size and Composition of the SOE Sector in OECD Countries", OECD Corporate Governance Working Papers, No. 1, OECD Publishing, Paris. http://dx.doi.org/10.1787/5kg9xfgidhg6-en

Christiansen, H. and K. Kane (2013), "The size and sectoral distribution of SOEs in OECD countries", Working Party on State Ownership and Privatisation Practices, OECD, Paris. DAF/CA/SOPP(2013)9

Cowling, K. and M. Waterson (1976), "Price-cost margins and market structure", Economica, 43(171), 267-274.

Domowitz, I., R. G. Hubbard and B. C. Petersen (1986), "Business Cycles and the Relationship between Concentration and Price-Cost Margins", The RAND Journal of Economics, 17(1), 1-17.

Eriotis, N. P., Zoe F. and Z. Ventoura-Neokosmides (2011), "Profit Margin and Capital Structure: An Empirical Relationship", Journal of Applied Business Research (JABR), 18(2).

Gal, P. N. (2013), "Measuring Total Factor Productivity at the Firm Level using OECD-ORBIS", OECD Economics Department Working Papers, No. 1049, OECD Publishing, Paris. http://dx.doi.org/10.1787/5k46dsb25Is6-en

Kowalski, P., M. B., M. Sztajerowska and M. Egeland (2012), "State-Owned Enterprises: Trade Effects and Policy Implications", OECD Trade Policy Paper No. 147, OECD Publishing, Paris. http://dx.doi.org/10.1787/5k4869ckqk7l-en

Machin, S. and J. V. Reenen (1993), "Profit Margins and the Business Cycle: Evidence from UK Manufacturing Firms." The Journal of Industrial Economics, 41(1), 29-50.

OECD (2008), "The Role of State-Owned Enterprises in the Economy: An Initial Review of the Evidence" Working Group on Privatisation and Corporate Governance of State Owned Assets, OECD, Paris. DAF/CA/PRIV(2008) 9

OECD (2011), Corporate Governance of State-Owned Enterprises: Change and Reform in OECD Countries since 2005, OECD Publishing, Paris. http://dx.doi.org/10.1787/9789264119529-en

OECD (2012), Competitive Neutrality: Maintaining a Level Playing Field between Public and Private Business, OECD Publishing, Paris. http://dx.doi.org/10.1787/9789264178953-en

OECD (2013a), "Maintaining a Level Playing Field between Public and Private Business for Growth and Development", Background Report to the 2013 Meeting of the Council at Ministerial Level, $\underline{\mathrm{C} / \mathrm{MIN}(2013) 18 .}$

OECD (2013b), "A Stock-Taking of International Investment by State-Owned Enterprises and of Relevant Elements of National and International Policy Frameworks", DAF/INV/WD(2013)5. 
OECD (2013c), "State-Owned Enterprises in the Development Process", Working Party on State Ownership and Privatisation Practices, OECD, Paris. DAF/CA/SOPP(2013)3

OECD (2014), Financing State-Owned Enterprises: An Overview of National Practices, OECD Publishing, Paris. http://dx.doi.org/10.1787/9789264209091-en

Ragoussis, A. and E. Gonnard (2012), "The Oecd-Orbis Database Treatment and Benchmarking Procedures", mimeo OECD, Paris.

Ribeiro, S., S. Menghinello and K. D. Backer (2010), "The OECD ORBIS Database: Responding to the Need for Firm-Level Micro-Data in the OECD", OECD Statistics Working Papers, 2010/01, OECD Publishing, Paris. http://dx.doi.org/10.1787/5kmhds8mzj8w-en 
ANNEX

Table A1. Distribution of SIEs indicators in Forbes Global 2000 (for the selected 5 sectors)

\begin{tabular}{|c|c|c|c|c|c|c|c|c|c|c|}
\hline \multirow{2}{*}{$\begin{array}{l}\text { Forbes } \\
\text { Rank }\end{array}$} & \multirow{2}{*}{ Company } & \multirow{2}{*}{ Industry } & \multirow{2}{*}{ Country } & \multirow{2}{*}{$\begin{array}{c}\text { Market } \\
\text { value } \\
\text { (B\$) }\end{array}$} & \multirow{2}{*}{$\begin{array}{l}\text { Sales } \\
\text { (B\$) }\end{array}$} & \multirow{2}{*}{$\begin{array}{l}\text { Pro- } \\
\text { fits } \\
\text { (B\$) }\end{array}$} & \multirow{2}{*}{$\begin{array}{l}\text { Ass- } \\
\text { ets } \\
\text { (B\$) }\end{array}$} & \multicolumn{3}{|c|}{$\begin{array}{l}\text { State investment? } \\
\text { (1: yes; 0: no) }\end{array}$} \\
\hline & & & & & & & & $>10 \%$ & $>25 \%$ & $>50 \%$ \\
\hline 5 & Exxon Mobil & $\begin{array}{c}\text { Oil \& Gas } \\
\text { Operations }\end{array}$ & United States & 400.4 & 420.7 & 44.9 & 334 & 0 & 0 & 0 \\
\hline 7 & $\begin{array}{l}\text { Royal Dutch } \\
\text { Shell }\end{array}$ & $\begin{array}{l}\text { Oil \& Gas } \\
\text { Operations }\end{array}$ & Netherlands & 213.1 & 467.2 & 26.6 & 360 & 0 & 0 & 0 \\
\hline 10 & PetroChina & $\begin{array}{l}\text { Oil \& Gas } \\
\text { Operations }\end{array}$ & China & 261.2 & 308.9 & 18.3 & 348 & 1 & 1 & 1 \\
\hline 13 & Chevron & $\begin{array}{l}\text { Oil \& Gas } \\
\text { Operations }\end{array}$ & United States & 232.5 & 222.6 & 26.2 & 233 & 0 & 0 & 0 \\
\hline 17 & Gazprom & $\begin{array}{l}\text { Oil \& Gas } \\
\text { Operations }\end{array}$ & Russia & 111.4 & 144 & 40.6 & 339 & 1 & 1 & 1 \\
\hline 18 & $\mathrm{BP}$ & $\begin{array}{l}\text { Oil \& Gas } \\
\text { Operations }\end{array}$ & $\begin{array}{l}\text { United } \\
\text { Kingdom }\end{array}$ & 130.4 & 370.9 & 11.6 & 301 & 0 & 0 & 0 \\
\hline 20 & Petrobras & $\begin{array}{l}\text { Oil \& Gas } \\
\text { Operations }\end{array}$ & Brazil & 120.7 & 144.1 & 11 & 332 & 1 & 1 & 1 \\
\hline 23 & Total & $\begin{array}{l}\text { Oil \& Gas } \\
\text { Operations }\end{array}$ & France & 115.5 & 240.5 & 14.1 & 224 & 0 & 0 & 0 \\
\hline 24 & AT\&T & $\begin{array}{l}\text { Telecommunica- } \\
\text { tions services }\end{array}$ & United States & 200.1 & 127.4 & 7.3 & 272 & 0 & 0 & 0 \\
\hline 26 & $\begin{array}{l}\text { Sinopec-China } \\
\text { Petroleum }\end{array}$ & $\begin{array}{l}\text { Oil \& Gas } \\
\text { Operations }\end{array}$ & China & 106.9 & 411.7 & 10.1 & 200 & 1 & 1 & 1 \\
\hline 29 & China Mobile & $\begin{array}{l}\text { Telecommunica- } \\
\text { tions services }\end{array}$ & $\begin{array}{l}\text { Hong Kong, } \\
\text { China }\end{array}$ & 213.8 & 88.8 & 20.5 & 169 & 1 & 1 & 1 \\
\hline 30 & ENI & $\begin{array}{l}\text { Oil \& Gas } \\
\text { Operations }\end{array}$ & Italy & 86.3 & 163.7 & 10 & 185 & 1 & 1 & 0 \\
\hline 33 & Vodafone & $\begin{array}{l}\text { Telecommunica- } \\
\text { tions services }\end{array}$ & $\begin{array}{l}\text { United } \\
\text { Kingdom }\end{array}$ & 135.7 & 74.4 & 11.1 & 220 & 0 & 0 & 0 \\
\hline 38 & Statoil & $\begin{array}{c}\text { Oil \& Gas } \\
\text { Operations }\end{array}$ & Norway & 78.1 & 126.8 & 12.4 & 140 & 1 & 1 & 1 \\
\hline 44 & BHP Billiton & $\begin{array}{l}\text { Diversified Metals } \\
\text { \& Mining }\end{array}$ & Australia & 184.7 & 72.2 & 15.4 & 129 & 0 & 0 & 0 \\
\hline 47 & $\begin{array}{c}\text { Nippon } \\
\text { Telegraph \& Tel }\end{array}$ & $\begin{array}{l}\text { Telecommunica- } \\
\text { tions services }\end{array}$ & Japan & 58.2 & 126.9 & 5.6 & 226 & 1 & 1 & 0 \\
\hline 59 & Rosneft & $\begin{array}{l}\text { Oil \& Gas } \\
\text { Operations }\end{array}$ & Russia & 73.2 & 68.8 & 11.2 & 126 & 1 & 1 & 1 \\
\hline 63 & Telefónica & $\begin{array}{l}\text { Telecommunica- } \\
\text { tions services }\end{array}$ & Spain & 67.1 & 82.3 & 5.2 & 162 & 0 & 0 & 0 \\
\hline 64 & Lukoil & $\begin{array}{l}\text { Oil \& Gas } \\
\text { Operations }\end{array}$ & Russia & 55.4 & 116.3 & 11 & 99 & 0 & 0 & 0 \\
\hline 73 & ConocoPhillips & $\begin{array}{l}\text { Oil \& Gas } \\
\text { Operations }\end{array}$ & United States & 72.1 & 58.4 & 8.4 & 117 & 0 & 0 & 0 \\
\hline 74 & EDF & Electric Utilities & France & 35.3 & 95.9 & 4.4 & 325 & 1 & 1 & 1 \\
\hline 95 & GDF Suez & Electric Utilities & France & 45 & 128 & 2 & 269 & 1 & 1 & 0 \\
\hline 99 & E.ON & Electric Utilities & Germany & 32.5 & 174.2 & 2.9 & 185 & 0 & 0 & 0 \\
\hline
\end{tabular}




\begin{tabular}{|c|c|c|c|c|c|c|c|c|c|c|}
\hline \multirow{2}{*}{$\begin{array}{l}\text { Forbes } \\
\text { Rank }\end{array}$} & \multirow{2}{*}{ Company } & \multirow{2}{*}{ Industry } & \multirow{2}{*}{ Country } & \multirow{2}{*}{$\begin{array}{c}\text { Market } \\
\text { value } \\
\text { (B\$) }\end{array}$} & \multirow{2}{*}{$\begin{array}{l}\text { Sales } \\
\text { (B\$) }\end{array}$} & \multirow{2}{*}{$\begin{array}{l}\text { Pro- } \\
\text { fits } \\
\text { (B\$) }\end{array}$} & \multirow{2}{*}{$\begin{array}{l}\text { Ass- } \\
\text { ets } \\
\text { (B\$) }\end{array}$} & \multicolumn{3}{|c|}{$\begin{array}{l}\text { State investment? } \\
\text { (1: yes; 0: no) }\end{array}$} \\
\hline & & & & & & & & $>10 \%$ & $>25 \%$ & $>50 \%$ \\
\hline 100 & América Móvil & $\begin{array}{l}\text { Telecommunica- } \\
\text { tions services }\end{array}$ & Mexico & 70.7 & 60.2 & 7.1 & 74.6 & 0 & 0 & 0 \\
\hline 111 & Cnooc & $\begin{array}{l}\text { Oil \& Gas } \\
\text { Operations }\end{array}$ & $\begin{array}{l}\text { Hong Kong, } \\
\text { China }\end{array}$ & 84.3 & 39.2 & 10.1 & 73.2 & 1 & 1 & 1 \\
\hline 114 & Ecopetrol & $\begin{array}{l}\text { Oil \& Gas } \\
\text { Operations }\end{array}$ & Colombia & 116.2 & 39 & 8.4 & 64.4 & 1 & 1 & 1 \\
\hline 115 & $\begin{array}{c}\text { China Shenhua } \\
\text { Energy }\end{array}$ & $\begin{array}{l}\text { Diversified Metals } \\
\quad \& \text { Mining }\end{array}$ & China & 70.8 & 39.7 & 7.7 & 70.2 & 1 & 1 & 1 \\
\hline 121 & $\begin{array}{l}\text { Reliance } \\
\text { Industries }\end{array}$ & $\begin{array}{c}\text { Oil \& Gas } \\
\text { Operations }\end{array}$ & India & 50.4 & 70.3 & 3.9 & 64.2 & 0 & 0 & 0 \\
\hline 124 & Iberdrola & Electric Utilities & Spain & 33.6 & 45.1 & 3.7 & 122 & 0 & 0 & 0 \\
\hline 130 & Phillips 66 & $\begin{array}{l}\text { Oil \& Gas } \\
\text { Operations }\end{array}$ & United States & 39.9 & 166.1 & 4.1 & 48.1 & 0 & 0 & 0 \\
\hline 134 & $\begin{array}{c}\text { Verizon } \\
\text { Communications }\end{array}$ & $\begin{array}{l}\text { Telecommunica- } \\
\text { tions services }\end{array}$ & United States & 137.3 & 115.8 & 0.9 & 225 & 0 & 0 & 0 \\
\hline 139 & China Telecom & $\begin{array}{l}\text { Telecommunica- } \\
\text { tions services }\end{array}$ & China & 42 & 44.9 & 2.4 & 87.4 & 1 & 1 & 1 \\
\hline 141 & Repsol YPF & $\begin{array}{c}\text { Oil \& Gas } \\
\text { Operations }\end{array}$ & Spain & 28.8 & 77.7 & 2.7 & 81.2 & 0 & 0 & 0 \\
\hline 142 & Suncor Energy & $\begin{array}{l}\text { Oil \& Gas } \\
\text { Operations }\end{array}$ & Canada & 47.3 & 38.8 & 2.8 & 76.8 & 0 & 0 & 0 \\
\hline 144 & PTT PCL & $\begin{array}{l}\text { Oil \& Gas } \\
\text { Operations }\end{array}$ & Thailand & 32.9 & 89.9 & 3.4 & 53.3 & 1 & 1 & 1 \\
\hline 145 & ENEL & Electric Utilities & Italy & 32.2 & 111.9 & 1.1 & 226 & 1 & 1 & 0 \\
\hline 148 & Softbank & $\begin{array}{l}\text { Telecommunica- } \\
\text { tions services }\end{array}$ & Japan & 47.2 & 38.7 & 3.8 & 58.3 & 0 & 0 & 0 \\
\hline 151 & $\begin{array}{l}\text { Occidental } \\
\text { Petroleum }\end{array}$ & $\begin{array}{c}\text { Oil \& Gas } \\
\text { Operations }\end{array}$ & United States & 67.4 & 24.3 & 4.6 & 64.2 & 0 & 0 & 0 \\
\hline 155 & $\begin{array}{c}\text { Oil \& Natural } \\
\text { Gas }\end{array}$ & $\begin{array}{l}\text { Oil \& Gas } \\
\text { Operations }\end{array}$ & India & 50.5 & 28.9 & 5.5 & 52.1 & 1 & 1 & 1 \\
\hline 157 & $\begin{array}{c}\text { Glencore } \\
\text { International }\end{array}$ & $\begin{array}{l}\text { Diversified Metals } \\
\quad \& \text { Mining }\end{array}$ & Switzerland & 41.7 & 214.4 & 1 & 106 & 0 & 0 & 0 \\
\hline 159 & TNK-BP Holding & $\begin{array}{l}\text { Oil \& Gas } \\
\text { Operations }\end{array}$ & Russia & 33 & 43.3 & 7.6 & 43.3 & 0 & 0 & 0 \\
\hline 163 & BG Group & $\begin{array}{c}\text { Oil \& Gas } \\
\text { Operations }\end{array}$ & $\begin{array}{l}\text { United } \\
\text { Kingdom }\end{array}$ & 60.6 & 19.3 & 4.6 & 64.4 & 0 & 0 & 0 \\
\hline 169 & France Telecom & $\begin{array}{l}\text { Telecommunica- } \\
\text { tions services }\end{array}$ & France & 29.2 & 57.4 & 1.5 & 114 & 1 & 1 & 0 \\
\hline 177 & RWE Group & Electric Utilities & Germany & 22.9 & 67 & 1.7 & 112 & 0 & 0 & 0 \\
\hline 187 & Surgutneftegas & $\begin{array}{l}\text { Oil \& Gas } \\
\text { Operations }\end{array}$ & Russia & 33.7 & 23.4 & 7.2 & 51.4 & 0 & 0 & 0 \\
\hline 197 & Valero Energy & $\begin{array}{l}\text { Oil \& Gas } \\
\text { Operations }\end{array}$ & United States & 24.4 & 139.2 & 2.1 & 44.5 & 0 & 0 & 0 \\
\hline 198 & Duke Energy & Electric Utilities & United States & 49.3 & 19.6 & 1.8 & 114 & 0 & 0 & 0 \\
\hline 199 & KDDI & $\begin{array}{l}\text { Telecommunica- } \\
\text { tions services }\end{array}$ & Japan & 29.1 & 43.2 & 2.9 & 47.4 & 0 & 0 & 0 \\
\hline 200 & Telstra & $\begin{array}{l}\text { Telecommunica- } \\
\text { tions services }\end{array}$ & Australia & 58.4 & 25.8 & 3.5 & 40.5 & 0 & 0 & 0 \\
\hline 202 & Xstrata & $\begin{array}{l}\text { Diversified Metals } \\
\quad \& \text { Mining }\end{array}$ & Switzerland & 52.1 & 32.3 & 1.2 & 83.1 & 0 & 0 & 0 \\
\hline 214 & JX Holdings & $\begin{array}{l}\text { Oil \& Gas } \\
\text { Operations }\end{array}$ & Japan & 14.4 & 129.5 & 2.1 & 80.7 & 0 & 0 & 0 \\
\hline
\end{tabular}




\begin{tabular}{|c|c|c|c|c|c|c|c|c|c|c|}
\hline \multirow{2}{*}{$\begin{array}{l}\text { Forbes } \\
\text { Rank }\end{array}$} & \multirow{2}{*}{ Company } & \multirow{2}{*}{ Industry } & \multirow{2}{*}{ Country } & \multirow{2}{*}{$\begin{array}{l}\text { Market } \\
\text { value } \\
\text { (B\$) }\end{array}$} & \multirow{2}{*}{$\begin{array}{l}\text { Sales } \\
\text { (B\$) }\end{array}$} & \multirow{2}{*}{$\begin{array}{l}\text { Pro- } \\
\text { fits } \\
\text { (B\$) }\end{array}$} & \multirow{2}{*}{$\begin{array}{l}\text { Ass- } \\
\text { ets } \\
\text { (B\$) }\end{array}$} & \multicolumn{3}{|c|}{$\begin{array}{l}\text { State investment? } \\
\text { (1: yes; 0: no) }\end{array}$} \\
\hline & & & & & & & & $>10 \%$ & $>25 \%$ & $>50 \%$ \\
\hline 217 & China Unicom & $\begin{array}{l}\text { Telecommunica- } \\
\text { tions services }\end{array}$ & $\begin{array}{l}\text { Hong Kong, } \\
\text { China }\end{array}$ & 32.4 & 39.5 & 1.1 & 82.8 & 1 & 1 & 1 \\
\hline 222 & BT Group & $\begin{array}{l}\text { Telecommunica- } \\
\text { tions services }\end{array}$ & $\begin{array}{l}\text { United } \\
\text { Kingdom }\end{array}$ & 32.5 & 30.9 & 3.2 & 37.3 & 0 & 0 & 0 \\
\hline 225 & $\begin{array}{l}\text { Marathon } \\
\text { Petroleum }\end{array}$ & $\begin{array}{l}\text { Oil \& Gas } \\
\text { Operations }\end{array}$ & United States & 29.1 & 76.5 & 3.4 & 27.2 & 0 & 0 & 0 \\
\hline 229 & Southern Co & Electric Utilities & United States & 39.6 & 16.5 & 2.4 & 63.1 & 0 & 0 & 0 \\
\hline 236 & Hess & $\begin{array}{l}\text { Oil \& Gas } \\
\text { Operations }\end{array}$ & United States & 24.8 & 37.7 & 2 & 43.4 & 0 & 0 & 0 \\
\hline 241 & BCE & $\begin{array}{l}\text { Telecommunica- } \\
\text { tions services }\end{array}$ & Canada & 35.6 & 20 & 2.8 & 41.2 & 0 & 0 & 0 \\
\hline 255 & Apache & $\begin{array}{l}\text { Oil \& Gas } \\
\text { Operations }\end{array}$ & United States & 29.6 & 17.1 & 2 & 60.7 & 0 & 0 & 0 \\
\hline 259 & Exelon & Electric Utilities & United States & 28.5 & 23.5 & 1.2 & 78.6 & 0 & 0 & 0 \\
\hline 267 & $\begin{array}{l}\text { Anadarko } \\
\text { Petroleum }\end{array}$ & $\begin{array}{l}\text { Oil \& Gas } \\
\text { Operations }\end{array}$ & United States & 42.7 & 13.4 & 2.4 & 52.6 & 0 & 0 & 0 \\
\hline 270 & VimpelCom & $\begin{array}{l}\text { Telecommunica- } \\
\text { tions services }\end{array}$ & $\begin{array}{l}\text { Norway(Neth } \\
\text { erlands) }\end{array}$ & 19 & 23.1 & 2.1 & 55.4 & 1 & 0 & 0 \\
\hline 273 & $\begin{array}{l}\text { Freeport- } \\
\text { McMoRan } \\
\text { Copper }\end{array}$ & $\begin{array}{l}\text { Diversified Metals } \\
\quad \& \text { Mining }\end{array}$ & United States & 32.1 & 18 & 3 & 35.4 & 0 & 0 & 0 \\
\hline 282 & NextEra Energy & Electric Utilities & United States & 31.6 & 14.3 & 1.9 & 64.4 & 0 & 0 & 0 \\
\hline 286 & TeliaSonera & $\begin{array}{l}\text { Telecommunica- } \\
\text { tions services }\end{array}$ & Sweden & 31 & 16.1 & 3.1 & 38.1 & 1 & 1 & 0 \\
\hline 288 & $\begin{array}{l}\text { Canadian } \\
\text { Natural } \\
\text { Resources }\end{array}$ & $\begin{array}{l}\text { Oil \& Gas } \\
\text { Operations }\end{array}$ & Canada & 36 & 14.7 & 1.9 & 49.2 & 0 & 0 & 0 \\
\hline 289 & Husky Energy & $\begin{array}{l}\text { Oil \& Gas } \\
\text { Operations }\end{array}$ & Canada & 29 & 22.5 & 2 & 35.3 & 0 & 0 & 0 \\
\hline 295 & SingTel & $\begin{array}{l}\text { Telecommunica- } \\
\text { tions services }\end{array}$ & Singapore & 45.7 & 15 & 3.2 & 31.4 & 1 & 1 & 1 \\
\hline 304 & OMV Group & $\begin{array}{l}\text { Oil \& Gas } \\
\text { Operations }\end{array}$ & Austria & 14.7 & 56.3 & 1.8 & 39.8 & 1 & 1 & 0 \\
\hline 326 & Telenor & $\begin{array}{l}\text { Telecommunica- } \\
\text { tions services }\end{array}$ & Norway & 34.1 & 18.3 & 1.7 & 29.6 & 1 & 1 & 1 \\
\hline 339 & $\begin{array}{l}\text { American } \\
\text { Electric }\end{array}$ & Electric Utilities & United States & 23.3 & 14.9 & 1.3 & 54.4 & 0 & 0 & 0 \\
\hline 342 & Inpex & $\begin{array}{l}\text { Oil \& Gas } \\
\text { Operations }\end{array}$ & Japan & 20.6 & 14.3 & 2.3 & 36.9 & 0 & 0 & 0 \\
\hline 346 & MTN Group & $\begin{array}{l}\text { Telecommunica- } \\
\text { tions services }\end{array}$ & South Africa & 34.5 & 16.5 & 2.5 & 21.4 & 0 & 0 & 0 \\
\hline 348 & Marathon Oil & $\begin{array}{l}\text { Oil \& Gas } \\
\text { Operations }\end{array}$ & United States & 24.8 & 15.6 & 1.6 & 35.3 & 0 & 0 & 0 \\
\hline 350 & Indian Oil & $\begin{array}{l}\text { Oil \& Gas } \\
\text { Operations }\end{array}$ & India & 14.2 & 70.8 & 0.8 & 43.2 & 1 & 1 & 1 \\
\hline 359 & Saudi Telecom & $\begin{array}{l}\text { Telecommunica- } \\
\text { tions services }\end{array}$ & Saudi Arabia & 21.7 & 15.8 & 1.9 & 31.3 & 1 & 1 & 1 \\
\hline 361 & Delta Air Lines & Airline & United States & 13.6 & 36.7 & 1 & 44.6 & 0 & 0 & 0 \\
\hline 366 & SK Innovation & $\begin{array}{l}\text { Oil \& Gas } \\
\text { Operations }\end{array}$ & South Korea & 13.7 & 65.1 & 1.1 & 31.8 & 0 & 0 & 0 \\
\hline 369 & CenturyLink & $\begin{array}{l}\text { Telecommunica- } \\
\text { tions services }\end{array}$ & United States & 21.5 & 18.4 & 0.8 & 54 & 0 & 0 & 0 \\
\hline
\end{tabular}




\begin{tabular}{|c|c|c|c|c|c|c|c|c|c|c|}
\hline \multirow{2}{*}{$\begin{array}{l}\text { Forbes } \\
\text { Rank }\end{array}$} & \multirow{2}{*}{ Company } & \multirow{2}{*}{ Industry } & \multirow{2}{*}{ Country } & \multirow{2}{*}{$\begin{array}{c}\text { Market } \\
\text { value } \\
\text { (B\$) }\end{array}$} & \multirow{2}{*}{$\begin{array}{c}\text { Sales } \\
\text { (B\$) }\end{array}$} & \multirow{2}{*}{$\begin{array}{l}\text { Pro- } \\
\text { fits } \\
\text { (B\$) }\end{array}$} & \multirow{2}{*}{$\begin{array}{l}\text { Ass- } \\
\text { ets } \\
\text { (B\$) }\end{array}$} & \multicolumn{3}{|c|}{$\begin{array}{l}\text { State investment? } \\
\text { (1: yes; 0: no) }\end{array}$} \\
\hline & & & & & & & & $>10 \%$ & $>\mathbf{2 5 \%}$ & $>50 \%$ \\
\hline 376 & $\begin{array}{c}\text { EDP-Energias de } \\
\text { Portugal }\end{array}$ & Electric Utilities & Portugal & 11.5 & 21.6 & 1.3 & 55.2 & 1 & 1 & 0 \\
\hline 377 & Coal India & $\begin{array}{c}\text { Diversified Metals } \\
\text { \& Mining }\end{array}$ & India & 37.4 & 12.3 & 2.9 & 20.8 & 1 & 1 & 1 \\
\hline 384 & NTPC & Electric Utilities & India & 22.3 & 12.8 & 1.9 & 30.5 & 1 & 1 & 1 \\
\hline 385 & Norilsk Nickel & $\begin{array}{c}\text { Diversified Metals } \\
\text { \& Mining }\end{array}$ & Russia & 32.9 & 12.8 & 3.3 & 18.8 & 0 & 0 & 0 \\
\hline 389 & PPL & Electric Utilities & United States & 17.8 & 12.3 & 1.5 & 43.6 & 0 & 0 & 0 \\
\hline 398 & PG\&E & Electric Utilities & United States & 19.1 & 15 & 0.8 & 52.4 & 0 & 0 & 0 \\
\hline 403 & $\begin{array}{l}\text { Deutsche } \\
\text { Lufthansa }\end{array}$ & Airline & Germany & 9.7 & 39.7 & 1.3 & 37.5 & 0 & 0 & 0 \\
\hline 404 & $\begin{array}{l}\text { Huaneng Power } \\
\text { International }\end{array}$ & Electric Utilities & China & 14.9 & 21.1 & 0.9 & 41.2 & 1 & 1 & 1 \\
\hline 405 & SK Holdings & $\begin{array}{l}\text { Oil \& Gas } \\
\text { Operations }\end{array}$ & South Korea & 7 & 106.3 & 0.9 & 85.2 & 0 & 0 & 0 \\
\hline 418 & FirstEnergy & Electric Utilities & United States & 17.6 & 15.3 & 0.8 & 50.4 & 0 & 0 & 0 \\
\hline 427 & Cenovus Energy & $\begin{array}{l}\text { Oil \& Gas } \\
\text { Operations }\end{array}$ & Canada & 24.4 & 16.9 & 1 & 24.3 & 0 & 0 & 0 \\
\hline 429 & CEZ Group & Electric Utilities & $\begin{array}{c}\text { Czech } \\
\text { Republic }\end{array}$ & 15.7 & 11.3 & 2.2 & 33.4 & 1 & 1 & 1 \\
\hline 432 & $\begin{array}{l}\text { Consolidated } \\
\text { Edison }\end{array}$ & Electric Utilities & United States & 17.3 & 12.2 & 1.1 & 41.2 & 0 & 0 & 0 \\
\hline 433 & $\begin{array}{l}\text { Deutsche } \\
\text { Telekom }\end{array}$ & $\begin{array}{l}\text { Telecommunica- } \\
\text { tions services }\end{array}$ & Germany & 48.4 & 76.7 & -6.9 & 136 & 1 & 1 & 0 \\
\hline 434 & Swisscom & $\begin{array}{l}\text { Telecommunica- } \\
\text { tions services }\end{array}$ & Switzerland & 24 & 12.4 & 1.9 & 21.5 & 1 & 1 & 1 \\
\hline 435 & Rio Tinto & $\begin{array}{l}\text { Diversified Metals } \\
\quad \& \text { Mining }\end{array}$ & $\begin{array}{l}\text { United } \\
\text { Kingdom }\end{array}$ & 98.5 & 51 & -3 & 118 & 0 & 0 & 0 \\
\hline 437 & CLP Holdings & Electric Utilities & $\begin{array}{l}\text { Hong Kong, } \\
\text { China }\end{array}$ & 21.7 & 13.5 & 1.1 & 29.4 & 0 & 0 & 0 \\
\hline 440 & Grupo Mexico & $\begin{array}{c}\text { Diversified Metals } \\
\text { \& Mining }\end{array}$ & Mexico & 32.3 & 10.4 & 2.4 & 18.4 & 0 & 0 & 0 \\
\hline 448 & $\begin{array}{l}\text { Newmont } \\
\text { Mining }\end{array}$ & $\begin{array}{c}\text { Diversified Metals } \\
\& \text { Mining }\end{array}$ & United States & 19.7 & 9.9 & 1.8 & 29.6 & 0 & 0 & 0 \\
\hline 449 & $\begin{array}{c}\text { Rogers } \\
\text { Communications }\end{array}$ & $\begin{array}{l}\text { Telecommunica- } \\
\text { tions services }\end{array}$ & Canada & 25.3 & 12.5 & 1.7 & 19.7 & 0 & 0 & 0 \\
\hline 456 & Bharti Airtel & $\begin{array}{l}\text { Telecommunica- } \\
\text { tions services }\end{array}$ & India & 21.8 & 14 & 0.8 & 29.8 & 1 & 1 & 0 \\
\hline 473 & $\begin{array}{l}\text { China Coal } \\
\text { Energy }\end{array}$ & $\begin{array}{l}\text { Diversified Metals } \\
\quad \& \text { Mining }\end{array}$ & China & 12.2 & 13.6 & 1.5 & 29.5 & 1 & 1 & 1 \\
\hline 475 & $\begin{array}{l}\text { EnBW-Energie } \\
\text { Baden }\end{array}$ & Electric Utilities & Germany & 10.8 & 24.7 & 0.6 & 48.5 & 0 & 0 & 0 \\
\hline 480 & Fortum & Electric Utilities & Finland & 17.6 & 8.1 & 1.9 & 32.3 & 1 & 1 & 1 \\
\hline 483 & $\begin{array}{l}\text { Woodside } \\
\text { Petroleum }\end{array}$ & $\begin{array}{c}\text { Oil \& Gas } \\
\text { Operations }\end{array}$ & Australia & 31.9 & 6.4 & 3 & 23.9 & 0 & 0 & 0 \\
\hline 484 & Tatneft & $\begin{array}{l}\text { Oil \& Gas } \\
\text { Operations }\end{array}$ & Russia & 14.8 & 13 & 2.1 & 19.5 & 1 & 1 & 0 \\
\hline 489 & $\begin{array}{l}\text { Public Service } \\
\text { Enterprise }\end{array}$ & Electric Utilities & United States & 16.8 & 9.8 & 1.3 & 31.7 & 0 & 0 & 0 \\
\hline 494 & Origin Energy & Electric Utilities & Australia & 14.9 & 13.2 & 1 & 28.7 & 0 & 0 & 0 \\
\hline
\end{tabular}




\begin{tabular}{|c|c|c|c|c|c|c|c|c|c|c|}
\hline \multirow{2}{*}{$\begin{array}{l}\text { Forbes } \\
\text { Rank }\end{array}$} & \multirow{2}{*}{ Company } & \multirow{2}{*}{ Industry } & \multirow{2}{*}{ Country } & \multirow{2}{*}{$\begin{array}{l}\text { Market } \\
\text { value } \\
\text { (B\$) }\end{array}$} & \multirow{2}{*}{$\begin{array}{l}\text { Sales } \\
\text { (B\$) }\end{array}$} & \multirow{2}{*}{$\begin{array}{l}\text { Pro- } \\
\text { fits } \\
\text { (B\$) }\end{array}$} & \multirow{2}{*}{$\begin{array}{l}\text { Ass- } \\
\text { ets } \\
\text { (B\$) }\end{array}$} & \multicolumn{3}{|c|}{$\begin{array}{l}\text { State investment? } \\
\text { (1: yes; 0: no) }\end{array}$} \\
\hline & & & & & & & & $>10 \%$ & $>25 \%$ & $>50 \%$ \\
\hline 496 & Telus & $\begin{array}{l}\text { Telecommunica- } \\
\text { tions services }\end{array}$ & Canada & 22.3 & 11 & 1.3 & 20.5 & 0 & 0 & 0 \\
\hline 498 & Etisalat & $\begin{array}{l}\text { Telecommunica- } \\
\text { tions services }\end{array}$ & $\begin{array}{l}\text { United Arab } \\
\text { Emirates }\end{array}$ & 21.8 & 9 & 1.8 & 21.8 & 1 & 1 & 1 \\
\hline 511 & EOG Resources & $\begin{array}{l}\text { Oil \& Gas } \\
\text { Operations }\end{array}$ & United States & 35.4 & 11.7 & 0.6 & 27.3 & 0 & 0 & 0 \\
\hline 513 & Teck Resources & $\begin{array}{c}\text { Diversified Metals } \\
\text { \& Mining }\end{array}$ & Canada & 17.4 & 10.4 & 0.8 & 34.8 & 0 & 0 & 0 \\
\hline 516 & Tenaga Nasional & Electric Utilities & Malaysia & 12.6 & 11.5 & 1.3 & 28.3 & 1 & 1 & 1 \\
\hline 522 & Anglo American & $\begin{array}{c}\text { Diversified Metals } \\
\text { \& Mining }\end{array}$ & $\begin{array}{l}\text { United } \\
\text { Kingdom }\end{array}$ & 39.9 & 29.4 & -1.5 & 78.1 & 0 & 0 & 0 \\
\hline 529 & Saudi Electricity & Electric Utilities & Saudi Arabia & 15.3 & 9 & 0.7 & 63.6 & 1 & 1 & 1 \\
\hline 531 & Murphy Oil & $\begin{array}{l}\text { Oil \& Gas } \\
\text { Operations }\end{array}$ & United States & 11.8 & 28.6 & 1 & 17.5 & 0 & 0 & 0 \\
\hline 536 & Vivendi & $\begin{array}{l}\text { Telecommunica- } \\
\text { tions services }\end{array}$ & France & 27.8 & 38.3 & 0.2 & 76.6 & 0 & 0 & 0 \\
\hline 539 & SSE & Electric Utilities & $\begin{array}{l}\text { United } \\
\text { Kingdom }\end{array}$ & 21.2 & 50.8 & 0.3 & 31.1 & 0 & 0 & 0 \\
\hline 548 & $\begin{array}{c}\text { Korea Electric } \\
\text { Power }\end{array}$ & Electric Utilities & South Korea & 17.4 & 43.9 & -2.8 & 129 & 1 & 1 & 1 \\
\hline 550 & KT Corp & $\begin{array}{l}\text { Telecommunica- } \\
\text { tions services }\end{array}$ & South Korea & 8.1 & 21.1 & 0.9 & 32.4 & 0 & 0 & 0 \\
\hline 553 & Entergy & Electric Utilities & United States & 11.6 & 10.3 & 0.9 & 43.2 & 0 & 0 & 0 \\
\hline 555 & SK Telecom & $\begin{array}{l}\text { Telecommunica- } \\
\text { tions services }\end{array}$ & South Korea & 11.5 & 14.5 & 1 & 24.1 & 0 & 0 & 0 \\
\hline 559 & Goldcorp & $\begin{array}{l}\text { Diversified Metals } \\
\quad \& \text { Mining }\end{array}$ & Canada & 26.4 & 5.4 & 1.7 & 31.2 & 0 & 0 & 0 \\
\hline 560 & Xcel Energy & Electric Utilities & United States & 14.2 & 10.1 & 0.9 & 31.1 & 0 & 0 & 0 \\
\hline 578 & Novatek & $\begin{array}{l}\text { Oil \& Gas } \\
\text { Operations }\end{array}$ & Russia & 31.3 & 6.9 & 2.3 & 15.1 & 0 & 0 & 0 \\
\hline 588 & Telecom Italia & $\begin{array}{l}\text { Telecommunica- } \\
\text { tions services }\end{array}$ & Italy & 15.2 & 37.9 & -2.1 & 102 & 0 & 0 & 0 \\
\hline 589 & $\begin{array}{l}\text { Dominion } \\
\text { Resources }\end{array}$ & Electric Utilities & United States & 32.7 & 13.1 & 0.3 & 46.8 & 0 & 0 & 0 \\
\hline 597 & Cemig & Electric Utilities & Brazil & 10.7 & 9.5 & 2.2 & 19.4 & 1 & 1 & 1 \\
\hline 609 & Sprint Nextel & $\begin{array}{l}\text { Telecommunica- } \\
\text { tions services }\end{array}$ & United States & 17.5 & 35.3 & -4.3 & 51.6 & 0 & 0 & 0 \\
\hline 618 & $\begin{array}{l}\text { Chunghwa } \\
\text { Telecom }\end{array}$ & $\begin{array}{l}\text { Telecommunica- } \\
\text { tions services }\end{array}$ & $\begin{array}{l}\text { Chinese } \\
\text { Taipei }\end{array}$ & 24.3 & 7.4 & 1.4 & 15.2 & 0 & 0 & 0 \\
\hline 632 & Virgin Media & $\begin{array}{l}\text { Telecommunica- } \\
\text { tions services }\end{array}$ & United States & 12.5 & 6.7 & 4.6 & 17.1 & 0 & 0 & 0 \\
\hline 639 & $\begin{array}{c}\text { Datang } \\
\text { International } \\
\text { Power }\end{array}$ & Electric Utilities & China & 8.4 & 12.2 & 0.6 & 42.4 & 1 & 1 & 1 \\
\hline 644 & HollyFrontier & $\begin{array}{c}\text { Oil \& Gas } \\
\text { Operations }\end{array}$ & United States & 10.8 & 20.1 & 1.7 & 10.3 & 0 & 0 & 0 \\
\hline 645 & Galp Energia & $\begin{array}{c}\text { Oil \& Gas } \\
\text { Operations }\end{array}$ & Portugal & 13.1 & 24.4 & 0.5 & 18 & 0 & 0 & 0 \\
\hline 647 & Rostelecom & $\begin{array}{l}\text { Telecommunica- } \\
\text { tions services }\end{array}$ & Russia & 11.3 & 10.4 & 1.1 & 17.7 & 1 & 1 & 0 \\
\hline 649 & Japan Airlines & Airline & Japan & 8.7 & 14.6 & 2.3 & 13.2 & 0 & 0 & 0 \\
\hline
\end{tabular}




\begin{tabular}{|c|c|c|c|c|c|c|c|c|c|c|}
\hline \multirow{2}{*}{$\begin{array}{l}\text { Forbes } \\
\text { Rank }\end{array}$} & \multirow{2}{*}{ Company } & \multirow{2}{*}{ Industry } & \multirow{2}{*}{ Country } & \multirow{2}{*}{$\begin{array}{c}\text { Market } \\
\text { value } \\
\text { (B\$) }\end{array}$} & \multirow{2}{*}{$\begin{array}{l}\text { Sales } \\
\text { (B\$) }\end{array}$} & \multirow{2}{*}{$\begin{array}{l}\text { Pro- } \\
\text { fits } \\
\text { (B\$) }\end{array}$} & \multirow{2}{*}{$\begin{array}{l}\text { Ass- } \\
\text { ets } \\
\text { (B\$) }\end{array}$} & \multicolumn{3}{|c|}{$\begin{array}{l}\text { State investment? } \\
\text { (1: yes; 0: no) }\end{array}$} \\
\hline & & & & & & & & $>10 \%$ & $>\mathbf{2 5 \%}$ & $>50 \%$ \\
\hline 650 & Jiangxi Copper & $\begin{array}{l}\text { Diversified Metals } \\
\text { \& Mining }\end{array}$ & China & 10.8 & 25 & 0.8 & 12.5 & 1 & 1 & 0 \\
\hline 651 & PKN Orlen & $\begin{array}{l}\text { Oil \& Gas } \\
\text { Operations }\end{array}$ & Poland & 7.4 & 38.8 & 0.8 & 16.9 & 1 & 1 & 0 \\
\hline 657 & $\begin{array}{c}\text { China Resources } \\
\text { Power }\end{array}$ & Electric Utilities & $\begin{array}{l}\text { Hong Kong, } \\
\text { China }\end{array}$ & 12.4 & 8.1 & 1 & 22.9 & 1 & 1 & 1 \\
\hline 658 & Inter Rao & Electric Utilities & Russia & 7.2 & 18.3 & 1.2 & 16.6 & 1 & 0 & 0 \\
\hline 659 & Barrick Gold & $\begin{array}{c}\text { Diversified Metals } \\
\text { \& Mining }\end{array}$ & Canada & 28.7 & 14.5 & -0.7 & 47.3 & 0 & 0 & 0 \\
\hline 660 & $\begin{array}{c}\text { MOL Hungarian } \\
\text { Oil }\end{array}$ & $\begin{array}{c}\text { Oil \& Gas } \\
\text { Operations }\end{array}$ & Hungary & 7.5 & 24.6 & 0.7 & 21.6 & 1 & 1 & 0 \\
\hline 669 & $\begin{array}{l}\text { Ooredoo } \\
\text { Telecom }\end{array}$ & $\begin{array}{l}\text { Telecommunica- } \\
\text { tions services }\end{array}$ & Qatar & 10 & 9.3 & 0.8 & 25.9 & 1 & 1 & 0 \\
\hline 674 & $\begin{array}{l}\text { Yanzhou Coal } \\
\text { Mining }\end{array}$ & $\begin{array}{l}\text { Diversified Metals } \\
\text { \& Mining }\end{array}$ & China & 11.8 & 9.2 & 1 & 18 & 1 & 1 & 1 \\
\hline 681 & PGE & Electric Utilities & Poland & 10.5 & 9.4 & 1 & 18.8 & 1 & 1 & 1 \\
\hline 685 & Idemitsu Kosan & $\begin{array}{l}\text { Oil \& Gas } \\
\text { Operations }\end{array}$ & Japan & 3.5 & 52.1 & 0.8 & 32.4 & 0 & 0 & 0 \\
\hline 686 & $\begin{array}{l}\text { Telekom } \\
\text { Indonesia }\end{array}$ & $\begin{array}{l}\text { Telecommunica- } \\
\text { tions services }\end{array}$ & Indonesia & 21.4 & 8 & 1.3 & 11.5 & 1 & 1 & 1 \\
\hline 696 & MegaFon & $\begin{array}{l}\text { Telecommunica- } \\
\text { tions services }\end{array}$ & Russia & 17.6 & 8.8 & 1.2 & 11.5 & 0 & 0 & 0 \\
\hline 701 & KPN & $\begin{array}{l}\text { Telecommunica- } \\
\text { tions services }\end{array}$ & Netherlands & 5.5 & 16.4 & 0.9 & 27.2 & 0 & 0 & 0 \\
\hline 702 & DTE Energy & Electric Utilities & United States & 11.4 & 8.8 & 0.6 & 26.3 & 0 & 0 & 0 \\
\hline 706 & RusHydro & Electric Utilities & Russia & 6.9 & 11.3 & 1 & 25.3 & 1 & 1 & 1 \\
\hline 722 & $\begin{array}{c}\text { Chubu Electric } \\
\text { Power } \\
\text { United }\end{array}$ & Electric Utilities & Japan & 9 & 29.6 & -1.1 & 65.8 & 0 & 0 & 0 \\
\hline 736 & $\begin{array}{l}\text { Continental } \\
\text { Holdings }\end{array}$ & Airline & United States & 10.3 & 37.2 & -0.7 & 37.6 & 0 & 0 & 0 \\
\hline 740 & $\begin{array}{c}\text { China Yangtze } \\
\text { Power }\end{array}$ & Electric Utilities & China & 19.4 & 3.3 & 1.2 & 25.2 & 1 & 1 & 1 \\
\hline 745 & Newcrest Mining & $\begin{array}{l}\text { Diversified Metals } \\
\quad \& \text { Mining }\end{array}$ & Australia & 17.5 & 4.5 & 1.1 & 20.8 & 0 & 0 & 0 \\
\hline 751 & NRG Energy & Electric Utilities & United States & 8.4 & 8.4 & 0.6 & 35.1 & 0 & 0 & 0 \\
\hline 756 & Antofagasta & $\begin{array}{l}\text { Diversified Metals } \\
\quad \& \text { Mining }\end{array}$ & $\begin{array}{l}\text { United } \\
\text { Kingdom }\end{array}$ & 16.1 & 6.7 & 1 & 12.9 & 0 & 0 & 0 \\
\hline 760 & $\begin{array}{c}\text { Kansai Electric } \\
\text { Power }\end{array}$ & Electric Utilities & Japan & 7 & 34 & -2.9 & 86.7 & 0 & 0 & 0 \\
\hline 762 & S-Oil & $\begin{array}{l}\text { Oil \& Gas } \\
\text { Operations }\end{array}$ & South Korea & 9.4 & 30.8 & 0.5 & 11.7 & 0 & 0 & 0 \\
\hline 763 & $\begin{array}{l}\text { Northeast } \\
\text { Utilities }\end{array}$ & Electric Utilities & United States & 13.4 & 6.3 & 0.5 & 28.3 & 0 & 0 & 0 \\
\hline 764 & $\begin{array}{c}\text { Formosa } \\
\text { Petrochemical }\end{array}$ & $\begin{array}{l}\text { Oil \& Gas } \\
\text { Operations }\end{array}$ & $\begin{array}{l}\text { Chinese } \\
\text { Taipei }\end{array}$ & 26.5 & 30.2 & 0.1 & 15.4 & 0 & 0 & 0 \\
\hline 766 & Tesoro & $\begin{array}{c}\text { Oil \& Gas } \\
\text { Operations }\end{array}$ & United States & 7.8 & 33 & 0.7 & 10.7 & 0 & 0 & 0 \\
\hline 768 & Devon Energy & $\begin{array}{l}\text { Oil \& Gas } \\
\text { Operations }\end{array}$ & United States & 23.6 & 9.5 & -0.2 & 43.3 & 0 & 0 & 0 \\
\hline 771 & $\begin{array}{l}\text { Southwest } \\
\text { Airlines }\end{array}$ & Airline & United States & 9 & 17.1 & 0.4 & 18.6 & 0 & 0 & 0 \\
\hline
\end{tabular}




\begin{tabular}{|c|c|c|c|c|c|c|c|c|c|c|}
\hline \multirow{2}{*}{$\begin{array}{l}\text { Forbes } \\
\text { Rank }\end{array}$} & \multirow{2}{*}{ Company } & \multirow{2}{*}{ Industry } & \multirow{2}{*}{ Country } & \multirow{2}{*}{$\begin{array}{c}\text { Market } \\
\text { value } \\
\text { (B\$) }\end{array}$} & \multirow{2}{*}{$\begin{array}{l}\text { Sales } \\
\text { (B\$) }\end{array}$} & \multirow{2}{*}{$\begin{array}{l}\text { Pro- } \\
\text { fits } \\
\text { (B\$) }\end{array}$} & \multirow{2}{*}{$\begin{array}{l}\text { Ass- } \\
\text { ets } \\
\text { (B\$) }\end{array}$} & \multicolumn{3}{|c|}{$\begin{array}{l}\text { State investment? } \\
\text { (1: yes; 0: no) }\end{array}$} \\
\hline & & & & & & & & $>10 \%$ & $>25 \%$ & $>50 \%$ \\
\hline 772 & $\begin{array}{c}\text { Edison } \\
\text { International }\end{array}$ & Electric Utilities & United States & 16.6 & 11.9 & -0.1 & 44.4 & 0 & 0 & 0 \\
\hline 782 & $\begin{array}{c}\text { Chesapeake } \\
\text { Energy }\end{array}$ & $\begin{array}{l}\text { Oil \& Gas } \\
\text { Operations }\end{array}$ & United States & 15 & 12.3 & -0.8 & 41.6 & 0 & 0 & 0 \\
\hline 785 & $\begin{array}{l}\text { KGHM Polska } \\
\text { Miedz }\end{array}$ & $\begin{array}{l}\text { Diversified Metals } \\
\text { \& Mining }\end{array}$ & Poland & 10.7 & 8.7 & 1.6 & 10.7 & 1 & 1 & 0 \\
\hline 786 & Pgnig Group & $\begin{array}{c}\text { Oil \& Gas } \\
\text { Operations }\end{array}$ & Poland & 11 & 8.8 & 0.7 & 15.5 & 1 & 1 & 1 \\
\hline 790 & Sistema & $\begin{array}{l}\text { Telecommunica- } \\
\text { tions services }\end{array}$ & Russia & 8.1 & 30 & 0.2 & 43.7 & 0 & 0 & 0 \\
\hline 791 & Noble Energy & $\begin{array}{c}\text { Oil \& Gas } \\
\text { Operations }\end{array}$ & United States & 20.8 & 4.2 & 1 & 17.6 & 0 & 0 & 0 \\
\hline 793 & Mobily & $\begin{array}{l}\text { Telecommunica- } \\
\text { tions services }\end{array}$ & Saudi Arabia & 16.3 & 6.3 & 1.6 & 10.3 & 1 & 1 & 0 \\
\hline 797 & IDGC Holding & Electric Utilities & Russia & 2.6 & 19.7 & 0.7 & 27.3 & 1 & 1 & 1 \\
\hline 799 & $\begin{array}{c}\text { GD Power } \\
\text { Development }\end{array}$ & Electric Utilities & China & 8 & 8 & 0.6 & 29.2 & 1 & 1 & 1 \\
\hline 802 & Turk Telekom & $\begin{array}{l}\text { Telecommunica- } \\
\text { tions services }\end{array}$ & Turkey & 15 & 7.1 & 1.5 & 9.5 & 1 & 1 & 0 \\
\hline 806 & AES & Electric Utilities & United States & 9.3 & 18.1 & -0.9 & 41.8 & 0 & 0 & 0 \\
\hline 814 & $\begin{array}{l}\text { All Nippon } \\
\text { Airways }\end{array}$ & Airline & Japan & 7.8 & 17.1 & 0.3 & 23.5 & 0 & 0 & 0 \\
\hline 819 & Oi & $\begin{array}{l}\text { Telecommunica- } \\
\text { tions services }\end{array}$ & Brazil & 6.1 & 12.3 & 0.4 & 38 & 0 & 0 & 0 \\
\hline 821 & $\begin{array}{c}\text { Federal Grid of } \\
\text { UES }\end{array}$ & Electric Utilities & Russia & 7.2 & 4.3 & 1.5 & 36.2 & 1 & 1 & 1 \\
\hline 822 & $\begin{array}{c}\text { Sumitomo Metal } \\
\text { Mining }\end{array}$ & $\begin{array}{l}\text { Diversified Metals } \\
\quad \& \text { Mining }\end{array}$ & Japan & 8 & 10.2 & 0.8 & 13.9 & 0 & 0 & 0 \\
\hline 837 & CPFL Energia & Electric Utilities & Brazil & 10.4 & 7.7 & 0.6 & 15.2 & 0 & 0 & 0 \\
\hline 839 & $\begin{array}{c}\text { Tokyo Electric } \\
\text { Power }\end{array}$ & Electric Utilities & Japan & 3.6 & 64.6 & -9.4 & 189 & 0 & 0 & 0 \\
\hline 843 & Turkcell & $\begin{array}{l}\text { Telecommunica- } \\
\text { tions services }\end{array}$ & Turkey & 14.8 & 5.9 & 1.2 & 10.5 & 0 & 0 & 0 \\
\hline 859 & $\begin{array}{l}\text { China Southern } \\
\text { Airlines }\end{array}$ & Airline & China & 5.8 & 15.7 & 0.4 & 22.9 & 1 & 1 & 1 \\
\hline 868 & $\begin{array}{l}\text { China Eastern } \\
\text { Airlines }\end{array}$ & Airline & China & 5.7 & 13.5 & 0.5 & 19.4 & 1 & 1 & 1 \\
\hline 871 & $\begin{array}{l}\text { Power Assets } \\
\text { Holdings }\end{array}$ & Electric Utilities & $\begin{array}{l}\text { Hong Kong, } \\
\text { China }\end{array}$ & 19.5 & 1.3 & 1.3 & 13.1 & 0 & 0 & 0 \\
\hline 880 & $\begin{array}{l}\text { Zijin Mining } \\
\text { Group }\end{array}$ & $\begin{array}{l}\text { Diversified Metals } \\
\quad \& \text { Mining }\end{array}$ & China & 10.8 & 7.6 & 0.8 & 10.8 & 0 & 0 & 0 \\
\hline 887 & Belgacom & $\begin{array}{l}\text { Telecommunica- } \\
\text { tions services }\end{array}$ & Belgium & 8.9 & 8.5 & 0.9 & 10.7 & 1 & 1 & 1 \\
\hline 912 & $\begin{array}{l}\text { International } \\
\text { Airlines }\end{array}$ & Airline & $\begin{array}{l}\text { United } \\
\text { Kingdom }\end{array}$ & 7.6 & 23.9 & -1.2 & 25.6 & 0 & 0 & 0 \\
\hline 925 & $\begin{array}{l}\text { Industrias } \\
\text { Peñoles }\end{array}$ & $\begin{array}{l}\text { Diversified Metals } \\
\quad \& \text { Mining }\end{array}$ & Mexico & 17.4 & 7.4 & 0.8 & 6.4 & 0 & 0 & 0 \\
\hline 935 & Eletrobrás & Electric Utilities & Brazil & 5 & 17.5 & -3.5 & 84.1 & 1 & 1 & 1 \\
\hline 936 & $\begin{array}{l}\text { AngloGold } \\
\text { Ashanti }\end{array}$ & $\begin{array}{l}\text { Diversified Metals } \\
\quad \& \text { Mining }\end{array}$ & South Africa & 9.5 & 6.1 & 0.8 & 12.6 & 0 & 0 & 0 \\
\hline 959 & Ryanair Holdings & Airline & Ireland & 10.7 & 5.8 & 0.7 & 12 & 0 & 0 & 0 \\
\hline
\end{tabular}




\begin{tabular}{|c|c|c|c|c|c|c|c|c|c|c|}
\hline \multirow{2}{*}{$\begin{array}{l}\text { Forbes } \\
\text { Rank }\end{array}$} & \multirow{2}{*}{ Company } & \multirow{2}{*}{ Industry } & \multirow{2}{*}{ Country } & \multirow{2}{*}{$\begin{array}{c}\text { Market } \\
\text { value } \\
\text { (B\$) }\end{array}$} & \multirow{2}{*}{$\begin{array}{l}\text { Sales } \\
\text { (B\$) }\end{array}$} & \multirow{2}{*}{$\begin{array}{l}\text { Pro- } \\
\text { fits } \\
\text { (B\$) }\end{array}$} & \multirow{2}{*}{$\begin{array}{l}\text { Ass- } \\
\text { ets } \\
\text { (B\$) }\end{array}$} & \multicolumn{3}{|c|}{$\begin{array}{l}\text { State investment? } \\
\text { (1: yes; 0: no) }\end{array}$} \\
\hline & & & & & & & & $>10 \%$ & $>25 \%$ & $>50 \%$ \\
\hline 964 & $\begin{array}{l}\text { Advanced Info } \\
\text { Service }\end{array}$ & $\begin{array}{l}\text { Telecommunica- } \\
\text { tions services }\end{array}$ & Thailand & 23.2 & 4.6 & 1.1 & 3.1 & 0 & 0 & 0 \\
\hline 972 & $\begin{array}{l}\text { Singapore } \\
\text { Airlines }\end{array}$ & Airline & Singapore & 10 & 11.8 & 0.3 & 17.5 & 1 & 1 & 1 \\
\hline 1007 & Latam Airlines & Airline & Chile & 11.1 & 9.7 & 0 & 20.6 & 0 & 0 & 0 \\
\hline 1014 & Santos & $\begin{array}{l}\text { Oil \& Gas } \\
\text { Operations }\end{array}$ & Australia & 13.1 & 3.4 & 0.5 & 17.7 & 0 & 0 & 0 \\
\hline 1031 & $\begin{array}{c}\text { Tohoku Electric } \\
\text { Power }\end{array}$ & Electric Utilities & Japan & 3.6 & 20.4 & -2.8 & 48.9 & 0 & 0 & 0 \\
\hline 1035 & Air France-KLM & Airline & France & 3.1 & 33.8 & -1.6 & 34.7 & 1 & 0 & 0 \\
\hline 1043 & Talisman Energy & $\begin{array}{c}\text { Oil \& Gas } \\
\text { Operations }\end{array}$ & Canada & 12.7 & 7.3 & 0.1 & 21.9 & 0 & 0 & 0 \\
\hline 1045 & $\begin{array}{c}\text { Kyushu Electric } \\
\text { Power }\end{array}$ & Electric Utilities & Japan & 4.3 & 18.2 & -2 & 51.6 & 0 & 0 & 0 \\
\hline 1054 & Zain & $\begin{array}{l}\text { Telecommunica- } \\
\text { tions services }\end{array}$ & Kuwait & 10.8 & 4.6 & 0.9 & 10.4 & 1 & 1 & 0 \\
\hline 1056 & $\begin{array}{l}\text { Power Grid of } \\
\text { India }\end{array}$ & Electric Utilities & India & 9.3 & 2 & 0.6 & 18.2 & 1 & 1 & 1 \\
\hline 1060 & PLDT & $\begin{array}{l}\text { Telecommunica- } \\
\text { tions services }\end{array}$ & Philippines & 15.1 & 4 & 0.9 & 9.9 & 0 & 0 & 0 \\
\hline 1064 & $\begin{array}{l}\text { KazMunaiGas } \\
\text { Exploration }\end{array}$ & $\begin{array}{l}\text { Oil \& Gas } \\
\text { Operations }\end{array}$ & Kazakhstan & 7.9 & 5.3 & 1.1 & 10.4 & 1 & 1 & 1 \\
\hline 1076 & $\begin{array}{l}\text { Vedanta } \\
\text { Resources }\end{array}$ & $\begin{array}{l}\text { Diversified Metals } \\
\text { \& Mining }\end{array}$ & $\begin{array}{l}\text { United } \\
\text { Kingdom }\end{array}$ & 4.7 & 14 & 0.1 & 45.4 & 0 & 0 & 0 \\
\hline 1082 & $\begin{array}{c}\text { Cathay Pacific } \\
\text { Airways }\end{array}$ & Airline & $\begin{array}{l}\text { Hong Kong, } \\
\text { China }\end{array}$ & 7.1 & 12.6 & 0.1 & 20.5 & 1 & 1 & 1 \\
\hline 1105 & Terna & Electric Utilities & Italy & 8.3 & 2.3 & 0.6 & 18.6 & 1 & 1 & 0 \\
\hline 1109 & $\begin{array}{l}\text { Continental } \\
\text { Resources }\end{array}$ & $\begin{array}{l}\text { Oil \& Gas } \\
\text { Operations }\end{array}$ & United States & 17.2 & 2.6 & 0.7 & 9.1 & 0 & 0 & 0 \\
\hline 1112 & $\begin{array}{l}\text { Bharat } \\
\text { Petroleum }\end{array}$ & $\begin{array}{c}\text { Oil \& Gas } \\
\text { Operations }\end{array}$ & India & 5.4 & 36.7 & 0.2 & 15.3 & 1 & 1 & 1 \\
\hline 1113 & CMS Energy & Electric Utilities & United States & 7.3 & 6.3 & 0.4 & 17.1 & 0 & 0 & 0 \\
\hline 1122 & $\begin{array}{l}\text { Wisconsin } \\
\text { Energy }\end{array}$ & Electric Utilities & United States & 9.5 & 4.2 & 0.5 & 14.3 & 0 & 0 & 0 \\
\hline 1130 & $\begin{array}{l}\text { Canadian Oil } \\
\text { Sands }\end{array}$ & $\begin{array}{c}\text { Oil \& Gas } \\
\text { Operations }\end{array}$ & Canada & 10.2 & 3.7 & 1 & 10.2 & 0 & 0 & 0 \\
\hline 1134 & Tullow Oil & $\begin{array}{l}\text { Oil \& Gas } \\
\text { Operations }\end{array}$ & $\begin{array}{l}\text { United } \\
\text { Kingdom }\end{array}$ & 17.2 & 2.4 & 0.6 & 9.4 & 0 & 0 & 0 \\
\hline 1140 & Cosmo Oil & $\begin{array}{c}\text { Oil \& Gas } \\
\text { Operations }\end{array}$ & Japan & 1.8 & 37.6 & -0.1 & 20 & 0 & 0 & 0 \\
\hline 1141 & AMR & Airline & United States & 1.3 & 24.9 & -1.9 & 23.5 & 0 & 0 & 0 \\
\hline 1149 & $\begin{array}{c}\text { Chugoku Electric } \\
\text { Power }\end{array}$ & Electric Utilities & Japan & 4.4 & 14.3 & 0 & 34.2 & 0 & 0 & 0 \\
\hline 1159 & $\begin{array}{l}\text { First Quantum } \\
\text { Minerals }\end{array}$ & $\begin{array}{l}\text { Diversified Metals } \\
\quad \& \text { Mining }\end{array}$ & Canada & 10.2 & 3 & 1.8 & 7.5 & 0 & 0 & 0 \\
\hline 1166 & EnCana & $\begin{array}{c}\text { Oil \& Gas } \\
\text { Operations }\end{array}$ & Canada & 15 & 5.2 & -2.8 & 18.7 & 0 & 0 & 0 \\
\hline 1168 & Alrosa & $\begin{array}{l}\text { Diversified Metals } \\
\quad \& \text { Mining }\end{array}$ & Russia & 7.7 & 4.7 & 0.9 & 10 & 1 & 1 & 1 \\
\hline 1174 & NMDC & $\begin{array}{l}\text { Diversified Metals } \\
\text { \& Mining }\end{array}$ & India & 10.6 & 2.2 & 1.4 & 6.9 & 1 & 1 & 1 \\
\hline
\end{tabular}




\begin{tabular}{|c|c|c|c|c|c|c|c|c|c|c|}
\hline \multirow{2}{*}{$\begin{array}{l}\text { Forbes } \\
\text { Rank }\end{array}$} & \multirow{2}{*}{ Company } & \multirow{2}{*}{ Industry } & \multirow{2}{*}{ Country } & \multirow{2}{*}{$\begin{array}{c}\text { Market } \\
\text { value } \\
\text { (B\$) }\end{array}$} & \multirow{2}{*}{$\begin{array}{l}\text { Sales } \\
\text { (B\$) }\end{array}$} & \multirow{2}{*}{$\begin{array}{l}\text { Pro- } \\
\text { fits } \\
\text { (B\$) }\end{array}$} & \multirow{2}{*}{$\begin{array}{l}\text { Ass- } \\
\text { ets } \\
\text { (B\$) }\end{array}$} & \multicolumn{3}{|c|}{$\begin{array}{l}\text { State investment? } \\
\text { (1: yes; 0: no) }\end{array}$} \\
\hline & & & & & & & & $>10 \%$ & $>25 \%$ & $>50 \%$ \\
\hline 1178 & $\begin{array}{l}\text { US Airways } \\
\text { Group }\end{array}$ & Airline & United States & 2.6 & 13.8 & 0.6 & 9.4 & 0 & 0 & 0 \\
\hline 1181 & $\begin{array}{c}\text { Inner Mongolia } \\
\text { Yitai }\end{array}$ & $\begin{array}{c}\text { Diversified Metals } \\
\text { \& Mining }\end{array}$ & China & 8.7 & 5 & 1 & 6.4 & 1 & 1 & 1 \\
\hline 1192 & Fresnillo & $\begin{array}{l}\text { Diversified Metals } \\
\text { \& Mining }\end{array}$ & Mexico & 16.1 & 2.2 & 0.7 & 3.3 & 0 & 0 & 0 \\
\hline 1195 & Ameren & Electric Utilities & United States & 8.3 & 6.8 & -1 & 21.8 & 0 & 0 & 0 \\
\hline 1201 & $\begin{array}{l}\text { Portugal } \\
\text { Telecom }\end{array}$ & $\begin{array}{l}\text { Telecommunica- } \\
\text { tions services }\end{array}$ & Portugal & 4.7 & 8.5 & 0.3 & 26.5 & 0 & 0 & 0 \\
\hline 1203 & GS Holdings & $\begin{array}{l}\text { Oil \& Gas } \\
\text { Operations }\end{array}$ & South Korea & 5.4 & 8.7 & 0.4 & 12 & 0 & 0 & 0 \\
\hline 1210 & Turkish Airlines & Airline & Turkey & 4.8 & 8.3 & 0.6 & 10.5 & 1 & 1 & 0 \\
\hline 1217 & $\begin{array}{l}\text { Hindustan } \\
\text { Petroleum }\end{array}$ & $\begin{array}{l}\text { Oil \& Gas } \\
\text { Operations }\end{array}$ & India & 1.9 & 32.6 & 0 & 16.8 & 1 & 1 & 1 \\
\hline 1230 & Verbund & Electric Utilities & Austria & 7.4 & 4.1 & 0.5 & 16.3 & 1 & 1 & 1 \\
\hline 1242 & AGL Energy & Electric Utilities & Australia & 9.5 & 7.6 & 0.1 & 14.5 & 0 & 0 & 0 \\
\hline 1243 & $\begin{array}{l}\text { Mitsubishi } \\
\text { Materials }\end{array}$ & $\begin{array}{l}\text { Diversified Metals } \\
\quad \& \text { Mining }\end{array}$ & Japan & 3.8 & 17.4 & 0.1 & 21.1 & 0 & 0 & 0 \\
\hline 1254 & Qantas Airways & Airline & Australia & 4.1 & 16.1 & -0.3 & 21.7 & 0 & 0 & 0 \\
\hline 1256 & Orica & $\begin{array}{l}\text { Diversified Metals } \\
\quad \& \text { Mining }\end{array}$ & Australia & 9.6 & 6.9 & 0.4 & 7.7 & 0 & 0 & 0 \\
\hline 1260 & Maxis & $\begin{array}{l}\text { Telecommunica- } \\
\text { tions services }\end{array}$ & Malaysia & 15.6 & 2.9 & 0.6 & 5.8 & 0 & 0 & 0 \\
\hline 1272 & Consol Energy & $\begin{array}{l}\text { Diversified Metals } \\
\quad \& \text { Mining }\end{array}$ & United States & 7.7 & 5.4 & 0.4 & 12.7 & 0 & 0 & 0 \\
\hline 1279 & Yamana Gold & $\begin{array}{l}\text { Diversified Metals } \\
\quad \& \text { Mining }\end{array}$ & Canada & 11 & 2.3 & 0.4 & 11.8 & 0 & 0 & 0 \\
\hline 1288 & $\begin{array}{l}\text { Huadian Power } \\
\text { International }\end{array}$ & Electric Utilities & China & 4.8 & 9.4 & 0.2 & 26.4 & 1 & 1 & 0 \\
\hline 1293 & $\begin{array}{l}\text { Polyus Gold } \\
\text { International }\end{array}$ & $\begin{array}{l}\text { Diversified Metals } \\
\quad \& \text { Mining }\end{array}$ & $\begin{array}{l}\text { United } \\
\text { Kingdom }\end{array}$ & 9.8 & 2.8 & 0.9 & 5.6 & 0 & 0 & 0 \\
\hline 1295 & Red Eléctrica & Electric Utilities & Spain & 7.5 & 2.3 & 0.6 & 12 & 1 & 0 & 0 \\
\hline 1297 & $\begin{array}{l}\text { Showa Shell } \\
\text { Sekiyu }\end{array}$ & $\begin{array}{l}\text { Oil \& Gas } \\
\text { Operations }\end{array}$ & Japan & 2.6 & 30.3 & 0 & 14 & 0 & 0 & 0 \\
\hline 1308 & Manila Electric & Electric Utilities & Philippines & 9.2 & 6.8 & 0.4 & 5.3 & 0 & 0 & 0 \\
\hline 1311 & $\begin{array}{l}\text { Crown Castle } \\
\text { International }\end{array}$ & $\begin{array}{l}\text { Telecommunica- } \\
\text { tions services }\end{array}$ & United States & 20.5 & 2.4 & 0.2 & 16.1 & 0 & 0 & 0 \\
\hline 1313 & TDC & $\begin{array}{l}\text { Telecommunica- } \\
\text { tions services }\end{array}$ & Denmark & 6.4 & 4.6 & 0.6 & 11.2 & 0 & 0 & 0 \\
\hline 1318 & Essar Energy & $\begin{array}{c}\text { Oil \& Gas } \\
\text { Operations }\end{array}$ & $\begin{array}{l}\text { United } \\
\text { Kingdom }\end{array}$ & 2.9 & 16.7 & -0.6 & 17.4 & 0 & 0 & 0 \\
\hline 1319 & Tele2 & $\begin{array}{l}\text { Telecommunica- } \\
\text { tions services }\end{array}$ & Sweden & 7.4 & 6.7 & 0.5 & 6.9 & 0 & 0 & 0 \\
\hline 1320 & Aurubis & $\begin{array}{l}\text { Diversified Metals } \\
\quad \& \text { Mining }\end{array}$ & Germany & 3.1 & 17.7 & 0.5 & 6.3 & 0 & 0 & 0 \\
\hline 1331 & $\begin{array}{c}\text { Oil \& Gas } \\
\text { Development }\end{array}$ & $\begin{array}{l}\text { Oil \& Gas } \\
\text { Operations }\end{array}$ & Pakistan & 8.7 & 1.8 & 1 & 3.6 & 1 & 1 & 1 \\
\hline 1341 & Umicore & $\begin{array}{l}\text { Diversified Metals } \\
\quad \& \text { Mining }\end{array}$ & Belgium & 5.9 & 16.6 & 0.3 & 4.7 & 0 & 0 & 0 \\
\hline 1350 & $\begin{array}{l}\text { Eurasian Natural } \\
\text { Resources }\end{array}$ & $\begin{array}{l}\text { Diversified Metals } \\
\quad \& \text { Mining }\end{array}$ & $\begin{array}{l}\text { United } \\
\text { Kingdom }\end{array}$ & 6.8 & 6.3 & -0.8 & 20.2 & 0 & 0 & 0 \\
\hline
\end{tabular}




\begin{tabular}{|c|c|c|c|c|c|c|c|c|c|c|}
\hline \multirow{2}{*}{$\begin{array}{l}\text { Forbes } \\
\text { Rank }\end{array}$} & \multirow{2}{*}{ Company } & \multirow{2}{*}{ Industry } & \multirow{2}{*}{ Country } & \multirow{2}{*}{$\begin{array}{c}\text { Market } \\
\text { value } \\
\text { (B\$) }\end{array}$} & \multirow{2}{*}{$\begin{array}{l}\text { Sales } \\
\text { (B\$) }\end{array}$} & \multirow{2}{*}{$\begin{array}{l}\text { Pro- } \\
\text { fits } \\
\text { (B\$) }\end{array}$} & \multirow{2}{*}{$\begin{array}{l}\text { Ass- } \\
\text { ets } \\
\text { (B\$) }\end{array}$} & \multicolumn{3}{|c|}{$\begin{array}{l}\text { State investment? } \\
\text { (1: yes; 0: no) }\end{array}$} \\
\hline & & & & & & & & $>10 \%$ & $>25 \%$ & $>50 \%$ \\
\hline 1357 & Calpine & Electric Utilities & United States & 9.2 & 5.5 & 0.2 & 16.5 & 0 & 0 & 0 \\
\hline 1368 & Thai Oil & $\begin{array}{l}\text { Oil \& Gas } \\
\text { Operations }\end{array}$ & Thailand & 4.7 & 14.6 & 0.4 & 5.6 & 1 & 1 & 0 \\
\hline 1373 & Korean Air & Airline & South Korea & 2.6 & 11.3 & 0.2 & 21.6 & 0 & 0 & 0 \\
\hline 1385 & $\begin{array}{l}\text { Inner Mongolia } \\
\text { Rare-Earth }\end{array}$ & $\begin{array}{l}\text { Diversified Metals } \\
\quad \& \text { Mining }\end{array}$ & China & 11.8 & 1.8 & 0.6 & 2.2 & 1 & 1 & 1 \\
\hline 1394 & Silver Wheaton & $\begin{array}{l}\text { Diversified Metals } \\
\text { \& Mining }\end{array}$ & Canada & 10.8 & 0.8 & 0.6 & 3.2 & 0 & 0 & 0 \\
\hline 1395 & Scana & Electric Utilities & United States & 6.6 & 4.2 & 0.4 & 14.6 & 0 & 0 & 0 \\
\hline 1399 & $\mathrm{~A} 2 \mathrm{~A}$ & Electric Utilities & Italy & 1.9 & 8.1 & 0.3 & 15.8 & 1 & 1 & 1 \\
\hline 1400 & Caltex Australia & $\begin{array}{l}\text { Oil \& Gas } \\
\text { Operations }\end{array}$ & Australia & 6.2 & 24.2 & 0.1 & 5 & 0 & 0 & 0 \\
\hline 1401 & TAQA & Electric Utilities & $\begin{array}{l}\text { United Arab } \\
\text { Emirates }\end{array}$ & 2.2 & 7.5 & 0.2 & 33.3 & 1 & 1 & 1 \\
\hline 1405 & $\begin{array}{c}\text { Millicom } \\
\text { International }\end{array}$ & $\begin{array}{l}\text { Telecommunica- } \\
\text { tions services }\end{array}$ & Luxembourg & 8.2 & 4.9 & 0.5 & 7.9 & 0 & 0 & 0 \\
\hline 1406 & Peabody Energy & $\begin{array}{c}\text { Diversified Metals } \\
\& \text { Mining }\end{array}$ & United States & 5.9 & 8.1 & -0.6 & 15.8 & 0 & 0 & 0 \\
\hline 1407 & Taiwan Mobile & $\begin{array}{l}\text { Telecommunica- } \\
\text { tions services }\end{array}$ & $\begin{array}{l}\text { Chinese } \\
\text { Taipei }\end{array}$ & 12 & 3.4 & 0.5 & 3.2 & 0 & 0 & 0 \\
\hline 1408 & Alpiq Holding & Electric Utilities & France & 3.3 & 13.6 & -1.1 & 16.2 & 1 & 0 & 0 \\
\hline 1412 & Hellenic Telecom & $\begin{array}{l}\text { Telecommunica- } \\
\text { tions services }\end{array}$ & Greece & 3.7 & 6.2 & 0.6 & 10.7 & 1 & 0 & 0 \\
\hline 1429 & $\begin{array}{c}\text { Exxaro } \\
\text { Resources }\end{array}$ & $\begin{array}{l}\text { Diversified Metals } \\
\quad \& \text { Mining }\end{array}$ & South Africa & 6.4 & 1.5 & 1.2 & 4.9 & 0 & 0 & 0 \\
\hline 1432 & $\begin{array}{l}\text { Impala Platinum } \\
\text { Holdings }\end{array}$ & $\begin{array}{c}\text { Diversified Metals } \\
\text { \& Mining }\end{array}$ & South Africa & 9.3 & 3.4 & 0.5 & 8.9 & 0 & 0 & 0 \\
\hline 1435 & Gold Fields & $\begin{array}{l}\text { Diversified Metals } \\
\quad \& \text { Mining }\end{array}$ & South Africa & 5.9 & 3.4 & 0.7 & 11.2 & 0 & 0 & 0 \\
\hline 1437 & $\begin{array}{l}\text { Denbury } \\
\text { Resources }\end{array}$ & $\begin{array}{l}\text { Oil \& Gas } \\
\text { Operations }\end{array}$ & United States & 7 & 2.5 & 0.5 & 11.1 & 0 & 0 & 0 \\
\hline 1439 & $\begin{array}{l}\text { Pioneer Natural } \\
\text { Resources }\end{array}$ & $\begin{array}{l}\text { Oil \& Gas } \\
\text { Operations }\end{array}$ & United States & 17.3 & 3.2 & 0.2 & 13.1 & 0 & 0 & 0 \\
\hline 1446 & $\begin{array}{l}\text { Yang Quan Coal } \\
\text { Industry }\end{array}$ & $\begin{array}{l}\text { Diversified Metals } \\
\quad \& \text { Mining }\end{array}$ & China & 5.4 & 8 & 0.4 & 4.4 & 1 & 1 & 1 \\
\hline 1475 & $\begin{array}{l}\text { Electric Power } \\
\text { Development }\end{array}$ & Electric Utilities & Japan & 3.8 & 7.9 & 0.2 & 23.9 & 0 & 0 & 0 \\
\hline 1480 & Fortis (Canada) & Electric Utilities & Canada & 6.9 & 3.8 & 0.4 & 15 & 0 & 0 & 0 \\
\hline 1481 & Tauron Group & Electric Utilities & Poland & 2.5 & 7.6 & 0.5 & 10.1 & 1 & 1 & 0 \\
\hline 1490 & $\begin{array}{l}\text { Concho } \\
\text { Resources }\end{array}$ & $\begin{array}{l}\text { Oil \& Gas } \\
\text { Operations }\end{array}$ & United States & 10.1 & 1.8 & 0.4 & 8.6 & 0 & 0 & 0 \\
\hline 1496 & $\begin{array}{l}\text { Petronas } \\
\text { Dagangan }\end{array}$ & $\begin{array}{l}\text { Oil \& Gas } \\
\text { Operations }\end{array}$ & Malaysia & 7.4 & 9.6 & 0.3 & 3.2 & 1 & 1 & 1 \\
\hline 1518 & EasyJet & Airline & $\begin{array}{l}\text { United } \\
\text { Kingdom }\end{array}$ & 6.4 & 6.2 & 0.4 & 6.9 & 0 & 0 & 0 \\
\hline 1524 & Neste Oil & $\begin{array}{l}\text { Oil \& Gas } \\
\text { Operations }\end{array}$ & Finland & 3.8 & 23.7 & 0.2 & 9.7 & 1 & 1 & 1 \\
\hline 1530 & Public Power & Electric Utilities & Greece & 2 & 7.7 & 0 & 21.2 & 1 & 1 & 1 \\
\hline 1532 & $\begin{array}{c}\text { Crescent Point } \\
\text { Energy }\end{array}$ & $\begin{array}{l}\text { Oil \& Gas } \\
\text { Operations }\end{array}$ & Canada & 14.4 & 2 & 0.2 & 12.2 & 0 & 0 & 0 \\
\hline
\end{tabular}




\begin{tabular}{|c|c|c|c|c|c|c|c|c|c|c|}
\hline \multirow{2}{*}{$\begin{array}{l}\text { Forbes } \\
\text { Rank }\end{array}$} & \multirow{2}{*}{ Company } & \multirow{2}{*}{ Industry } & \multirow{2}{*}{ Country } & \multirow{2}{*}{$\begin{array}{l}\text { Market } \\
\text { value } \\
\text { (B\$) }\end{array}$} & \multirow{2}{*}{$\begin{array}{l}\text { Sales } \\
\text { (B\$) }\end{array}$} & \multirow{2}{*}{$\begin{array}{l}\text { Pro- } \\
\text { fits } \\
\text { (B\$) }\end{array}$} & \multirow{2}{*}{$\begin{array}{l}\text { Ass- } \\
\text { ets } \\
\text { (B\$) }\end{array}$} & \multicolumn{3}{|c|}{$\begin{array}{l}\text { State investment? } \\
\text { (1: yes; 0: no) }\end{array}$} \\
\hline & & & & & & & & $>10 \%$ & $>25 \%$ & $>50 \%$ \\
\hline 1546 & $\begin{array}{c}\text { Saudi Arabian } \\
\text { Mining }\end{array}$ & $\begin{array}{c}\text { Diversified Metals } \\
\text { \& Mining }\end{array}$ & Saudi Arabia & 8.1 & 1.5 & 0.3 & 14.7 & 1 & 1 & 1 \\
\hline 1551 & Kinross Gold & $\begin{array}{l}\text { Diversified Metals } \\
\text { \& Mining }\end{array}$ & Canada & 9.1 & 4.3 & -2.5 & 14.9 & 0 & 0 & 0 \\
\hline 1553 & $\begin{array}{c}\text { China } \\
\text { Communications } \\
\text { Services }\end{array}$ & $\begin{array}{l}\text { Telecommunica- } \\
\text { tions services }\end{array}$ & China & 4.7 & 9.8 & 0.4 & 7.2 & 1 & 1 & 1 \\
\hline 1560 & $\begin{array}{l}\text { Hokkaido } \\
\text { Electric Power }\end{array}$ & Electric Utilities & Japan & 1.7 & 7.7 & -0.9 & 19.6 & 0 & 0 & 0 \\
\hline 1565 & Pinnacle West & Electric Utilities & United States & 6.3 & 3.3 & 0.4 & 13.4 & 0 & 0 & 0 \\
\hline 1586 & Hyosung & $\begin{array}{c}\text { Diversified Metals } \\
\text { \& Mining }\end{array}$ & South Korea & 1.6 & 11.2 & 0.1 & 12.9 & 0 & 0 & 0 \\
\hline 1588 & $\begin{array}{c}\text { Plains } \\
\text { Exploration }\end{array}$ & $\begin{array}{l}\text { Oil \& Gas } \\
\text { Operations }\end{array}$ & United States & 6.1 & 2.6 & 0.3 & 17.3 & 0 & 0 & 0 \\
\hline 1595 & CVR Energy & $\begin{array}{l}\text { Oil \& Gas } \\
\text { Operations }\end{array}$ & United States & 4.8 & 8.6 & 0.4 & 3.6 & 0 & 0 & 0 \\
\hline 1601 & Buenaventura & $\begin{array}{l}\text { Diversified Metals } \\
\quad \& \text { Mining }\end{array}$ & Peru & 6.3 & 1.5 & 0.7 & 4.5 & 0 & 0 & 0 \\
\hline 1609 & Atco & Electric Utilities & Canada & 5 & 4.4 & 0.4 & 14.4 & 0 & 0 & 0 \\
\hline 1614 & $\begin{array}{c}\text { Shandong Gold- } \\
\text { Mining }\end{array}$ & $\begin{array}{c}\text { Diversified Metals } \\
\text { \& Mining }\end{array}$ & China & 7.6 & 6.3 & 0.3 & 2 & 1 & 1 & 1 \\
\hline 1617 & $\begin{array}{l}\text { Western } \\
\text { Refining }\end{array}$ & $\begin{array}{l}\text { Oil \& Gas } \\
\text { Operations }\end{array}$ & United States & 3.1 & 9.5 & 0.4 & 2.5 & 0 & 0 & 0 \\
\hline 1620 & NHPC & Electric Utilities & India & 4.6 & 1.4 & 0.6 & 11.8 & 1 & 1 & 1 \\
\hline 1632 & $\begin{array}{l}\text { Jizhong Energy } \\
\text { Resources }\end{array}$ & $\begin{array}{l}\text { Diversified Metals } \\
\quad \& \text { Mining }\end{array}$ & China & 4.9 & 6 & 0.5 & 6 & 1 & 1 & 1 \\
\hline 1638 & Oil India & $\begin{array}{c}\text { Oil \& Gas } \\
\text { Operations }\end{array}$ & India & 6.1 & 1.9 & 0.7 & 4.5 & 1 & 1 & 1 \\
\hline 1641 & $\begin{array}{c}\text { Pacific Rubiales } \\
\text { Energy }\end{array}$ & $\begin{array}{l}\text { Oil \& Gas } \\
\text { Operations }\end{array}$ & Canada & 7.1 & 3.9 & 0.5 & 7.1 & 0 & 0 & 0 \\
\hline 1648 & Boliden & $\begin{array}{l}\text { Diversified Metals } \\
\quad \& \text { Mining }\end{array}$ & Sweden & 4.6 & 6.2 & 0.5 & 6.1 & 0 & 0 & 0 \\
\hline 1660 & Korea Zinc & $\begin{array}{l}\text { Diversified Metals } \\
\text { \& Mining }\end{array}$ & South Korea & 5.7 & 4.9 & 0.5 & 4.6 & 0 & 0 & 0 \\
\hline 1673 & Pepco Holdings & Electric Utilities & United States & 4.8 & 5.1 & 0.3 & 15.8 & 0 & 0 & 0 \\
\hline 1688 & $\begin{array}{l}\text { Hellenic } \\
\text { Petroleum }\end{array}$ & $\begin{array}{l}\text { Oil \& Gas } \\
\text { Operations }\end{array}$ & Greece & 3.3 & 13.8 & 0.1 & 9.7 & 1 & 1 & 0 \\
\hline 1696 & $\begin{array}{c}\text { Shikoku Electric } \\
\text { Power }\end{array}$ & Electric Utilities & Japan & 2.3 & 7.2 & -0.1 & 16.3 & 0 & 0 & 0 \\
\hline 1702 & Windstream & $\begin{array}{l}\text { Telecommunica- } \\
\text { tions services }\end{array}$ & United States & 5.2 & 6.2 & 0.2 & 14 & 0 & 0 & 0 \\
\hline 1705 & $\begin{array}{l}\text { Randgold } \\
\text { Resources }\end{array}$ & $\begin{array}{l}\text { Diversified Metals } \\
\text { \& Mining }\end{array}$ & $\begin{array}{l}\text { Channel } \\
\text { Islands }\end{array}$ & 7.7 & 1.3 & 0.4 & 3.1 & 0 & 0 & 0 \\
\hline 1718 & PBF Energy & $\begin{array}{l}\text { Oil \& Gas } \\
\text { Operations }\end{array}$ & United States & 3.8 & 20.1 & 0 & 4.3 & 0 & 0 & 0 \\
\hline 1727 & Hanwa & $\begin{array}{l}\text { Diversified Metals } \\
\quad \& \text { Mining }\end{array}$ & Japan & 0.8 & 18.9 & 0.1 & 7.1 & 0 & 0 & 0 \\
\hline 1759 & OGE Energy & Electric Utilities & United States & 6.7 & 3.7 & 0.4 & 9.9 & 0 & 0 & 0 \\
\hline 1787 & $\begin{array}{l}\text { Emirates } \\
\text { Integrated } \\
\text { Telecom }\end{array}$ & $\begin{array}{l}\text { Telecommunica- } \\
\text { tions services }\end{array}$ & $\begin{array}{c}\text { United Arab } \\
\text { Emirates }\end{array}$ & 5.8 & 2.7 & 0.5 & 3.8 & 1 & 1 & 0 \\
\hline
\end{tabular}




\begin{tabular}{|c|c|c|c|c|c|c|c|c|c|c|}
\hline \multirow{2}{*}{$\begin{array}{l}\text { Forbes } \\
\text { Rank }\end{array}$} & \multirow{2}{*}{ Company } & \multirow{2}{*}{ Industry } & \multirow{2}{*}{ Country } & \multirow{2}{*}{$\begin{array}{c}\text { Market } \\
\text { value } \\
\text { (B\$) }\end{array}$} & \multirow{2}{*}{$\begin{array}{l}\text { Sales } \\
\text { (B\$) }\end{array}$} & \multirow{2}{*}{$\begin{array}{c}\text { Pro- } \\
\text { fits } \\
\text { (B\$) }\end{array}$} & \multirow{2}{*}{$\begin{array}{l}\text { Ass- } \\
\text { ets } \\
\text { (B\$) }\end{array}$} & \multicolumn{3}{|c|}{$\begin{array}{l}\text { State investment? } \\
\text { (1: yes; } 0: \text { no) }\end{array}$} \\
\hline & & & & & & & & $>10 \%$ & $>25 \%$ & $>50 \%$ \\
\hline 1794 & Saras & $\begin{array}{c}\text { Oil \& Gas } \\
\text { Operations }\end{array}$ & Italy & 1.1 & 15.7 & -0.1 & 5.2 & 0 & 0 & 0 \\
\hline 1803 & Air Canada & Airline & Canada & 0.7 & 12.2 & 0.1 & 9.1 & 0 & 0 & 0 \\
\hline 1808 & $\begin{array}{c}\text { Level } 3 \\
\text { Communications }\end{array}$ & $\begin{array}{l}\text { Telecommunica- } \\
\text { tions services }\end{array}$ & United States & 4.6 & 6.4 & -0.4 & 13.3 & 0 & 0 & 0 \\
\hline 1809 & $\begin{array}{c}\text { Hokuriku Electric } \\
\text { Power }\end{array}$ & Electric Utilities & Japan & 2.4 & 6 & -0.1 & 16.4 & 0 & 0 & 0 \\
\hline 1810 & LG Uplus & $\begin{array}{l}\text { Telecommunica- } \\
\text { tions services }\end{array}$ & South Korea & 3.5 & 10.2 & -0.1 & 9.9 & 0 & 0 & 0 \\
\hline 1820 & $\begin{array}{c}\text { Telecom of New } \\
\text { Zealand }\end{array}$ & $\begin{array}{l}\text { Telecommunica- } \\
\text { tions services }\end{array}$ & New Zealand & 3.4 & 3.5 & 0.9 & 2.9 & 0 & 0 & 0 \\
\hline 1826 & Grupa Lotos & $\begin{array}{c}\text { Oil \& Gas } \\
\text { Operations }\end{array}$ & Poland & 1.8 & 10.2 & 0.3 & 6.5 & 1 & 1 & 1 \\
\hline 1833 & Hainan Airlines & Airline & China & 4.5 & 4.4 & 0.3 & 14.9 & 1 & 1 & 0 \\
\hline 1834 & $\begin{array}{c}\text { China Hongqiao } \\
\text { Group }\end{array}$ & $\begin{array}{c}\text { Diversified Metals } \\
\text { \& Mining }\end{array}$ & China & 3 & 3.9 & 0.9 & 7.1 & 0 & 0 & 0 \\
\hline 1836 & $\begin{array}{l}\text { Total Access } \\
\text { Communication }\end{array}$ & $\begin{array}{l}\text { Telecommunica- } \\
\text { tions services }\end{array}$ & Thailand & 7.7 & 2.9 & 0.4 & 3.3 & 0 & 0 & 0 \\
\hline 1848 & $\begin{array}{c}\text { Alpha Natural } \\
\text { Resources }\end{array}$ & $\begin{array}{c}\text { Diversified Metals } \\
\text { \& Mining }\end{array}$ & United States & 1.9 & 7 & -2.4 & 13.1 & 0 & 0 & 0 \\
\hline 1849 & Zhongjin Gold & $\begin{array}{l}\text { Diversified Metals } \\
\text { \& Mining }\end{array}$ & China & 6.9 & 5.3 & 0.3 & 3 & 1 & 1 & 1 \\
\hline 1855 & $\begin{array}{c}\text { Far EasTone } \\
\text { Telecom }\end{array}$ & $\begin{array}{l}\text { Telecommunica- } \\
\text { tions services }\end{array}$ & $\begin{array}{l}\text { Chinese } \\
\text { Taipei }\end{array}$ & 7.6 & 3 & 0.4 & 3.4 & 0 & 0 & 0 \\
\hline 1864 & $\begin{array}{l}\text { Shanxi Lu'an } \\
\text { Environmental }\end{array}$ & $\begin{array}{c}\text { Diversified Metals } \\
\text { \& Mining }\end{array}$ & China & 6.7 & 3.1 & 0.4 & 6.4 & 1 & 1 & 1 \\
\hline 1869 & Cabot Oil \& Gas & $\begin{array}{c}\text { Oil \& Gas } \\
\text { Operations }\end{array}$ & United States & 14.1 & 1.2 & 0.1 & 4.6 & 0 & 0 & 0 \\
\hline 1891 & $\begin{array}{c}\text { Southwestern } \\
\text { Energy }\end{array}$ & $\begin{array}{c}\text { Oil \& Gas } \\
\text { Operations }\end{array}$ & United States & 13.5 & 2.7 & -0.7 & 6.7 & 0 & 0 & 0 \\
\hline 1902 & Dragon Oil & $\begin{array}{c}\text { Oil \& Gas } \\
\text { Operations }\end{array}$ & $\begin{array}{l}\text { United Arab } \\
\text { Emirates }\end{array}$ & 4.8 & 1.2 & 0.6 & 3.8 & 1 & 1 & 1 \\
\hline 1903 & $\begin{array}{l}\text { Nippon Steel } \\
\text { Trading }\end{array}$ & $\begin{array}{l}\text { Diversified Metals } \\
\quad \& \text { Mining }\end{array}$ & Japan & 0.4 & 13.1 & 0.1 & 4 & 0 & 0 & 0 \\
\hline 1904 & Range Resources & $\begin{array}{l}\text { Oil \& Gas } \\
\text { Operations }\end{array}$ & United States & 13.4 & 1.5 & 0 & 6.7 & 0 & 0 & 0 \\
\hline 1920 & Motor Oil & $\begin{array}{c}\text { Oil \& Gas } \\
\text { Operations }\end{array}$ & Greece & 1.2 & 12.8 & 0.1 & 3.4 & 0 & 0 & 0 \\
\hline 1923 & $\begin{array}{c}\text { Frontier } \\
\text { Communications }\end{array}$ & $\begin{array}{l}\text { Telecommunica- } \\
\text { tions services }\end{array}$ & United States & 4.1 & 5 & 0.1 & 17.7 & 0 & 0 & 0 \\
\hline 1933 & Alliant Energy & Electric Utilities & United States & 5.4 & 3.1 & 0.3 & 10.8 & 0 & 0 & 0 \\
\hline 1944 & $\begin{array}{c}\text { Tongling } \\
\text { Nonferrous } \\
\text { Metals }\end{array}$ & $\begin{array}{l}\text { Diversified Metals } \\
\quad \& \text { Mining }\end{array}$ & China & 3.9 & 12.2 & 0.1 & 5.9 & 1 & 1 & 1 \\
\hline 1949 & Assore & $\begin{array}{l}\text { Diversified Metals } \\
\text { \& Mining }\end{array}$ & South Africa & 5.2 & 1.6 & 0.5 & 2.1 & 0 & 0 & 0 \\
\hline 1951 & $\begin{array}{l}\text { Whiting } \\
\text { Petroleum }\end{array}$ & $\begin{array}{l}\text { Oil \& Gas } \\
\text { Operations }\end{array}$ & United States & 6.1 & 2.2 & 0.4 & 7.3 & 0 & 0 & 0 \\
\hline 1961 & $\begin{array}{l}\text { Telekom } \\
\text { Malaysia }\end{array}$ & $\begin{array}{l}\text { Telecommunica- } \\
\text { tions services }\end{array}$ & Malaysia & 6.1 & 3.2 & 0.4 & 7.3 & 1 & 1 & 1 \\
\hline 1970 & EQT & $\begin{array}{l}\text { Oil \& Gas } \\
\text { Operations }\end{array}$ & United States & 10 & 1.6 & 0.2 & 8.8 & 0 & 0 & 0 \\
\hline
\end{tabular}




\begin{tabular}{|c|c|c|c|c|c|c|c|c|c|c|}
\hline \multirow{2}{*}{$\begin{array}{c}\text { Forbes } \\
\text { Rank }\end{array}$} & \multirow{2}{*}{ Company } & \multirow{2}{*}{ Industry } & \multirow{2}{*}{ Country } & \multirow{2}{*}{$\begin{array}{c}\text { Market } \\
\text { value } \\
\text { (B\$) }\end{array}$} & \multirow{2}{*}{$\begin{array}{l}\text { Sales } \\
\text { (B\$) }\end{array}$} & \multirow{2}{*}{$\begin{array}{l}\text { Pro- } \\
\text { fits } \\
\text { (B\$) }\end{array}$} & \multirow{2}{*}{$\begin{array}{l}\text { Ass- } \\
\text { ets } \\
\text { (B\$) }\end{array}$} & \multicolumn{3}{|c|}{$\begin{array}{l}\text { State investment? } \\
\text { (1: yes; 0: no) }\end{array}$} \\
\hline & & & & & & & & $>10 \%$ & $>25 \%$ & $>50 \%$ \\
\hline 1974 & $\begin{array}{c}\text { Aeroflot-Russian } \\
\text { Airlines }\end{array}$ & Airline & Russia & 1.9 & 4.9 & 0.5 & 5.2 & 1 & 1 & 1 \\
\hline 1984 & $\begin{array}{c}\text { Reliance } \\
\text { Infrastructure }\end{array}$ & Electric Utilities & India & 2 & 4.7 & 0.3 & 12.1 & 0 & 0 & 0 \\
\hline 1985 & Cimarex Energy & $\begin{array}{l}\text { Oil \& Gas } \\
\text { Operations }\end{array}$ & United States & 6.8 & 1.6 & 0.4 & 6.3 & 0 & 0 & 0 \\
\hline 1996 & San-Ai Oil & $\begin{array}{l}\text { Oil \& Gas } \\
\text { Operations }\end{array}$ & Japan & 0.4 & 11.2 & 0.1 & 2.6 & 0 & 0 & 0 \\
\hline 1998 & $\begin{array}{l}\text { Interconexion } \\
\text { Electrica }\end{array}$ & Electric Utilities & Colombia & 5.8 & 2.4 & 0.2 & 14.6 & 1 & 1 & 1 \\
\hline
\end{tabular}

Source: OECD Secretariat based on ThomsonOne, Wikipedia and company announcement in 2012 
Table A2. The descriptive statistics information

\begin{tabular}{|c|c|c|c|c|c|}
\hline Variable & Observations & Mean & Std. Dev. & Min & Max \\
\hline ADDED_VALUE & 1398 & $3,623,976$ & $5,707,961$ & $-7,937,188$ & $38,200,000$ \\
\hline CASH_FLOW & 2849 & $2,117,024$ & $-4,045,164$ & $21,500,000$ & $40,700,000$ \\
\hline COST_GOODS & 2689 & $7,371,756$ & $16,800,000$ & 6.6 & $212,000,000$ \\
\hline COSTS_EMPLOYEES & 1432 & $1,124,498$ & $2,094,819$ & $-634,993$ & $16,100,000$ \\
\hline CURRENT_ASSETS & 2965 & $4,262,354$ & $7,721,228$ & 1.1 & $81,000,000$ \\
\hline CURRENT_ASSETS_DEBTORS & 2899 & $1,491,441$ & $3,368,506$ & $-38,564$ & $54,900,000$ \\
\hline CURRENT_LIAB & 2952 & $4,318,855$ & $7,513,997$ & 8.3 & $70,300,000$ \\
\hline CURRENT_LIAB_CREDITORS & 2855 & $1,267,526$ & $2,541,510$ & 0.9 & $46,100,000$ \\
\hline CURRENT_LIAB_LOANS & 2005 & $765,947.2$ & $1,897,316$ & 3.2 & $38,100,000$ \\
\hline CURRENT_RATIO & 2949 & 1.4 & 2.4 & 0 & 91.4 \\
\hline DEPRECIATION & 2849 & $1,273,457$ & $2,788,920$ & $-3,275,451$ & $40,500,000$ \\
\hline EBITDA & 2823 & $3,036,955$ & $-5,617,012$ & $16,900,000$ & $63,600,000$ \\
\hline EBITDA_MARGIN & 2806 & 30.5 & 20.3 & -88.2 & 100 \\
\hline EMPLOYEES & 2018 & 34,515 & $65,025.4$ & 250 & 631,866 \\
\hline ENTERPRISE_VALUE & 1910 & $18,900,000$ & $-29,700,000$ & $621,538.9$ & $310,000,000$ \\
\hline FIN_REVENUE & 2505 & $146,751.9$ & $552,959.7$ & $-7,022,868$ & $7,329,524$ \\
\hline FIXED_ASSETS & 2958 & $16,000,000$ & $27,200,000$ & 0.9 & $277,000,000$ \\
\hline GEARING & 2813 & 146.8 & 144.6 & 0 & $1,020.3$ \\
\hline GROSS_MARGIN & 2704 & 49.6 & 25.9 & -3.5 & 100 \\
\hline GROSS_PROFIT & 2704 & $5,509,298$ & $10,100,000$ & $-1,461,393$ & $108,000,000$ \\
\hline INTANGIBLE_FIXED_ASSETS & 2224 & $3,609,258$ & $12,700,000$ & $-333,335$ & $196,000,000$ \\
\hline INTEREST_PAID & 2843 & $383,736.3$ & $-823,109.5$ & $226,067.3$ & $18,400,000$ \\
\hline LIQUIDITY_RATIO & 2946 & 1.2 & 2.4 & 0 & 91.4 \\
\hline MATERIAL_COSTS & 429 & $5,126,515$ & $-11,300,000$ & $106,000,000$ & $97,500,000$ \\
\hline NACE_CORE & 3010 & $3,270.3$ & $2,051.9$ & 459.1 & $7,147.7$ \\
\hline NON_CURRENT_LIABILITIES & 2930 & $8,747,125$ & $15,400,000$ & 2.1 & $140,000,000$ \\
\hline NON_CURRENT_LIABILITIES_LTDEBT & 2839 & $4,923,411$ & $8,061,486$ & 3.2 & $79,000,000$ \\
\hline OP_REVENUE_PER_EMPLOYEE & 2019 & 935.6 & $1,537.5$ & 2 & 20,782 \\
\hline OPERATING_PL_EBIT & 2951 & $1,957,016$ & $-9,168,188$ & $22,000,000$ & $396,000,000$ \\
\hline OPERATING_REV_TURNOVER & 2979 & $12,800,000$ & $25,500,000$ & 1 & $315,000,000$ \\
\hline OTHER_OP_EXPENSES & 2903 & $3,925,079$ & $-7,523,501$ & $15,500,000$ & $107,000,000$ \\
\hline PL_AFTER_TAX & 2969 & $941,866.2$ & $-2,686,554$ & $28,000,000$ & $30,900,000$ \\
\hline PL_BEFORE_TAX & 2977 & $1,659,022$ & $-9,235,202$ & $28,900,000$ & $401,000,000$ \\
\hline PL_NET_INCOME_PERIOD & 2970 & $834,203.3$ & $-2,678,954$ & $31,400,000$ & $30,600,000$ \\
\hline PROFIT_MARGIN & 2938 & 15.3 & 18.7 & -98.6 & 100 \\
\hline PROFIT_PER_EMPLOYEE & 1936 & 120.6 & -272 & 112.5 & 6,977 \\
\hline RETURN_CAPITAL_EMPLOYED & 2827 & 12.6 & -22.5 & 750.1 & 316.2 \\
\hline RETURN_SHAREHOLDER_FUNDS & 2905 & 20.5 & -39.1 & 592 & 538 \\
\hline RETURN_TOTAL_ASSETS & 2957 & 8.1 & -10.6 & 74.2 & 87.8 \\
\hline SALES & 2925 & $12,400,000$ & $24,900,000$ & 32 & $304,000,000$ \\
\hline SALES_TURN & 3010 & $12,400,000$ & $24,900,000$ & 0 & $304,000,000$ \\
\hline SHAREHOLDERS_FUNDS & 2983 & $7,295,865$ & $-15,000,000$ & $21,700,000$ & $261,000,000$ \\
\hline STOCK_TURNOVER & 2806 & 46.9 & 81.8 & 0.3 & 915.6 \\
\hline TANGIBLE_FIXED_ASSETS & 2905 & $9,899,472$ & $16,400,000$ & 0 & $134,000,000$ \\
\hline TAXATION & 2866 & $553,285.5$ & $1,641,814$ & $-3,479,961$ & $24,100,000$ \\
\hline TOTAL_ASSETS & 2983 & $20,200,000$ & $33,400,000$ & 10.1 & $310,000,000$ \\
\hline WORKING_CAPITAL & 2720 & $918,148.2$ & $-3,003,838.0$ & $10,100,000.0$ & $71,300,000.0$ \\
\hline YEAR & 3010 & $2,005.5$ & 2.9 & $2,000.0$ & $2,010.0$ \\
\hline
\end{tabular}

Source: OECD corporate database 
Table A3. Nationality of acquirer in all deals and distribution of SIEs in the five sectors (1998-2012)

\begin{tabular}{|c|c|c|c|c|c|c|c|c|c|}
\hline \multirow{2}{*}{\multicolumn{2}{|c|}{ Rank Acquirer's Nationality }} & \multirow{2}{*}{$\begin{array}{c}\text { Non-SIEs } \\
\text { (Private } \\
\text { deals) }\end{array}$} & \multicolumn{6}{|c|}{ SIES } & \multirow{2}{*}{$\begin{array}{c}\text { Grand } \\
\text { Total }\end{array}$} \\
\hline & & & Air & Electricity & Mining & Oil \& Gas & Telecom & Total SIEs & \\
\hline 1 & China & 1,102 & 84 & 182 & 772 & 243 & 89 & 1370 & 2,472 \\
\hline 2 & Russian Federation & 1,618 & 7 & 300 & 23 & 463 & 66 & 859 & 2,477 \\
\hline 3 & France & 594 & 25 & 143 & 0 & 107 & 140 & 415 & 1,009 \\
\hline 4 & Italy & 617 & 0 & 126 & 0 & 90 & 0 & 216 & 833 \\
\hline 5 & Norway & 383 & 0 & 0 & 0 & 80 & 125 & 205 & 588 \\
\hline 6 & Brazil & 324 & 0 & 18 & 59 & 83 & 0 & 160 & 484 \\
\hline 7 & Japan & 978 & 0 & 0 & 0 & 0 & 155 & 155 & 1,133 \\
\hline 8 & India & 412 & 0 & 30 & 8 & 100 & 0 & 138 & 550 \\
\hline 9 & Germany & 1,166 & 0 & 2 & 0 & 1 & 134 & 137 & 1,303 \\
\hline 10 & Austria & 129 & 0 & 22 & 0 & 71 & 22 & 115 & 244 \\
\hline 11 & Finland & 214 & 2 & 39 & 2 & 4 & 55 & 102 & 316 \\
\hline 12 & Hungary & 46 & 0 & 0 & 0 & 47 & 28 & 75 & 121 \\
\hline 13 & Sweden & 609 & 17 & 0 & 0 & 1 & 53 & 71 & 680 \\
\hline 14 & Singapore & 149 & 9 & 0 & 0 & 6 & 52 & 67 & 216 \\
\hline 15 & Colombia & 65 & 0 & 42 & 1 & 22 & 0 & 65 & 130 \\
\hline 16 & Poland & 210 & 0 & 13 & 5 & 43 & 0 & 61 & 271 \\
\hline 17 & Malaysia & 290 & 4 & 0 & 0 & 56 & 0 & 60 & 350 \\
\hline 18 & Switzerland & 449 & 2 & 0 & 0 & 0 & 52 & 54 & 503 \\
\hline 19 & United Arab Emirates & 38 & 10 & 12 & 0 & 16 & 16 & 54 & 92 \\
\hline 20 & Denmark & 188 & 0 & 0 & 0 & 53 & 0 & 53 & 241 \\
\hline 21 & South Korea & 387 & 0 & 17 & 0 & 36 & 0 & 53 & 440 \\
\hline 22 & Czech Republic & 71 & 0 & 46 & 0 & 0 & 1 & 47 & 118 \\
\hline 23 & Indonesia & 182 & 0 & 3 & 12 & 12 & 19 & 46 & 228 \\
\hline 24 & Belgium & 130 & 0 & 1 & 0 & 6 & 30 & 37 & 167 \\
\hline 25 & Venezuela & 16 & 0 & 0 & 0 & 33 & 0 & 33 & 49 \\
\hline 26 & Slovenia & 18 & 0 & 0 & 0 & 12 & 17 & 29 & 47 \\
\hline 27 & Greece & 57 & 0 & 1 & 0 & 10 & 17 & 28 & 85 \\
\hline 28 & Qatar & 4 & 2 & 0 & 0 & 10 & 12 & 24 & 28 \\
\hline 29 & Hong Kong, China & 326 & 0 & 0 & 1 & 14 & 7 & 22 & 348 \\
\hline 30 & Kuwait & 35 & 0 & 0 & 0 & 20 & 0 & 20 & 55 \\
\hline 31 & Kazakhstan & 60 & 0 & 0 & 0 & 19 & 0 & 19 & 79 \\
\hline 32 & Oman & 13 & 0 & 0 & 0 & 17 & 0 & 17 & 30 \\
\hline 33 & Vietnam & 30 & 2 & 9 & 0 & 0 & 6 & 17 & 47 \\
\hline 34 & Chinese Taipei & 44 & 0 & 0 & 0 & 1 & 15 & 16 & 60 \\
\hline 35 & Thailand & 236 & 0 & 0 & 0 & 16 & 0 & 16 & 252 \\
\hline 36 & Azerbaijan & 2 & 0 & 0 & 0 & 15 & 0 & 15 & 17 \\
\hline 37 & Algeria & 3 & 0 & 0 & 0 & 12 & 0 & 12 & 15 \\
\hline 38 & Lithuania & 25 & 0 & 2 & 0 & 0 & 10 & 12 & 37 \\
\hline 39 & Spain & 654 & 0 & 11 & 0 & 0 & 0 & 11 & 665 \\
\hline 40 & New Zealand & 216 & 7 & 0 & 0 & 1 & 0 & 8 & 224 \\
\hline 41 & Saudi Arabia & 30 & 0 & 0 & 0 & 0 & 8 & 8 & 38 \\
\hline
\end{tabular}




\begin{tabular}{|c|c|c|c|c|c|c|c|c|c|}
\hline \multirow{2}{*}{\multicolumn{2}{|c|}{ Rank Acquirer's Nationality }} & \multirow{2}{*}{$\begin{array}{c}\text { Non-SIEs } \\
\text { (Private } \\
\text { deals) }\end{array}$} & \multicolumn{6}{|c|}{ SIES } & \multirow{2}{*}{$\begin{array}{l}\text { Grand } \\
\text { Total }\end{array}$} \\
\hline & & & Air & Electricity & Mining & Oil \& Gas & Telecom & Total SIEs & \\
\hline 42 & South Africa & 499 & 3 & 0 & 0 & 0 & 5 & 8 & 507 \\
\hline 43 & Turkey & 62 & 3 & 0 & 0 & 3 & 2 & 8 & 70 \\
\hline 44 & Morocco & 8 & 7 & 0 & 0 & 0 & 0 & 7 & 15 \\
\hline 45 & United Kingdom & 2,389 & 0 & 0 & 0 & 3 & 3 & 6 & 2,395 \\
\hline 46 & Chile & 138 & 0 & 5 & 0 & 0 & 0 & 5 & 143 \\
\hline 47 & United States & 10,981 & 0 & 3 & 0 & 2 & 0 & 5 & 10,986 \\
\hline 48 & Australia & 4,569 & 0 & 0 & 0 & 3 & 1 & 4 & 4,573 \\
\hline 49 & Egypt & 40 & 0 & 0 & 0 & 3 & 0 & 3 & 43 \\
\hline 50 & Kenya & 22 & 3 & 0 & 0 & 0 & 0 & 3 & 25 \\
\hline 51 & Argentina & 104 & 0 & 2 & 0 & 0 & 0 & 2 & 106 \\
\hline 52 & Canada & 7,872 & 0 & 0 & 2 & 0 & 0 & 2 & 7,874 \\
\hline 53 & Iraq & 1 & 0 & 0 & 0 & 1 & 1 & 2 & 3 \\
\hline 54 & Netherlands & 541 & 1 & 0 & 0 & 1 & 0 & 2 & 543 \\
\hline 55 & Angola & 11 & 0 & 0 & 0 & 1 & 0 & 1 & 12 \\
\hline 56 & New Caledonia & 1 & 0 & 0 & 0 & 1 & 0 & 1 & 2 \\
\hline 57 & Portugal & 150 & 0 & 0 & 0 & 1 & 0 & 1 & 151 \\
\hline 58 & Romania & 30 & 0 & 1 & 0 & 0 & 0 & 1 & 31 \\
\hline 59 & Afghanistan & 3 & 0 & 0 & 0 & 0 & 0 & 0 & 3 \\
\hline 60 & Albania & 3 & 0 & 0 & 0 & 0 & 0 & 0 & 3 \\
\hline 61 & American Samoa & 1 & 0 & 0 & 0 & 0 & 0 & 0 & 1 \\
\hline 62 & Anguilla & 2 & 0 & 0 & 0 & 0 & 0 & 0 & 2 \\
\hline 63 & Antigua and Barbuda & 1 & 0 & 0 & 0 & 0 & 0 & 0 & 1 \\
\hline 64 & Armenia & 7 & 0 & 0 & 0 & 0 & 0 & 0 & 7 \\
\hline 65 & Bahamas & 3 & 0 & 0 & 0 & 0 & 0 & 0 & 3 \\
\hline 66 & Bahrain & 8 & 0 & 0 & 0 & 0 & 0 & 0 & 8 \\
\hline 67 & Bangladesh & 1 & 0 & 0 & 0 & 0 & 0 & 0 & 1 \\
\hline 68 & Barbados & 3 & 0 & 0 & 0 & 0 & 0 & 0 & 3 \\
\hline 69 & Belarus & 4 & 0 & 0 & 0 & 0 & 0 & 0 & 4 \\
\hline 70 & Belize & 1 & 0 & 0 & 0 & 0 & 0 & 0 & 1 \\
\hline 71 & Bermuda & 50 & 0 & 0 & 0 & 0 & 0 & 0 & 50 \\
\hline 72 & Bolivia & 9 & 0 & 0 & 0 & 0 & 0 & 0 & 9 \\
\hline 73 & Bosnia and Herzegov. & 2 & 0 & 0 & 0 & 0 & 0 & 0 & 2 \\
\hline 74 & Bulgaria & 60 & 0 & 0 & 0 & 0 & 0 & 0 & 60 \\
\hline 75 & Cambodia & 4 & 0 & 0 & 0 & 0 & 0 & 0 & 4 \\
\hline 76 & Cayman Islands & 5 & 0 & 0 & 0 & 0 & 0 & 0 & 5 \\
\hline 77 & Central African Rep.. & 1 & 0 & 0 & 0 & 0 & 0 & 0 & 1 \\
\hline 78 & Congo & 1 & 0 & 0 & 0 & 0 & 0 & 0 & 1 \\
\hline 79 & Congo, Democratic Rep. & 4 & 0 & 0 & 0 & 0 & 0 & 0 & 4 \\
\hline 80 & Costa Rica & 2 & 0 & 0 & 0 & 0 & 0 & 0 & 2 \\
\hline 81 & Cote D'Ivoire & 2 & 0 & 0 & 0 & 0 & 0 & 0 & 2 \\
\hline 82 & Croatia & 18 & 0 & 0 & 0 & 0 & 0 & 0 & 18 \\
\hline 83 & Cuba & 2 & 0 & 0 & 0 & 0 & 0 & 0 & 2 \\
\hline 84 & Cyprus & 19 & 0 & 0 & 0 & 0 & 0 & 0 & 19 \\
\hline
\end{tabular}




\begin{tabular}{|c|c|c|c|c|c|c|c|c|c|}
\hline \multirow{2}{*}{\multicolumn{2}{|c|}{ Rank Acquirer's Nationality }} & \multirow{2}{*}{$\begin{array}{c}\text { Non-SIEs } \\
\text { (Private } \\
\text { deals) }\end{array}$} & \multicolumn{6}{|c|}{ SIES } & \multirow{2}{*}{$\begin{array}{l}\text { Grand } \\
\text { Total }\end{array}$} \\
\hline & & & Air & Electricity & Mining & Oil \& Gas & Telecom & Total SIEs & \\
\hline 85 & Dominican Republic & 11 & 0 & 0 & 0 & 0 & 0 & 0 & 11 \\
\hline 86 & Ecuador & 8 & 0 & 0 & 0 & 0 & 0 & 0 & 8 \\
\hline 87 & El Salvador & 1 & 0 & 0 & 0 & 0 & 0 & 0 & 1 \\
\hline 88 & Equatorial Guinea & 3 & 0 & 0 & 0 & 0 & 0 & 0 & 3 \\
\hline 89 & Estonia & 25 & 0 & 0 & 0 & 0 & 0 & 0 & 25 \\
\hline 90 & Ethiopia & 1 & 0 & 0 & 0 & 0 & 0 & 0 & 1 \\
\hline 91 & Faroe Islands & 11 & 0 & 0 & 0 & 0 & 0 & 0 & 11 \\
\hline 92 & Fiji & 3 & 0 & 0 & 0 & 0 & 0 & 0 & 3 \\
\hline 93 & French Polynesia & 1 & 0 & 0 & 0 & 0 & 0 & 0 & 1 \\
\hline 94 & Gabon & 1 & 0 & 0 & 0 & 0 & 0 & 0 & 1 \\
\hline 95 & Gambia & 1 & 0 & 0 & 0 & 0 & 0 & 0 & 1 \\
\hline 96 & Georgia & 9 & 0 & 0 & 0 & 0 & 0 & 0 & 9 \\
\hline 97 & Ghana & 4 & 0 & 0 & 0 & 0 & 0 & 0 & 4 \\
\hline 98 & Gibraltar & 1 & 0 & 0 & 0 & 0 & 0 & 0 & 1 \\
\hline 99 & Greenland & 2 & 0 & 0 & 0 & 0 & 0 & 0 & 2 \\
\hline 100 & Guam & 1 & 0 & 0 & 0 & 0 & 0 & 0 & 1 \\
\hline 101 & Guatemala & 3 & 0 & 0 & 0 & 0 & 0 & 0 & 3 \\
\hline 102 & Guernsey & 2 & 0 & 0 & 0 & 0 & 0 & 0 & 2 \\
\hline 103 & Guinea & 2 & 0 & 0 & 0 & 0 & 0 & 0 & 2 \\
\hline 104 & Guyana & 4 & 0 & 0 & 0 & 0 & 0 & 0 & 4 \\
\hline 105 & Honduras & 4 & 0 & 0 & 0 & 0 & 0 & 0 & 4 \\
\hline 106 & Iceland & 24 & 0 & 0 & 0 & 0 & 0 & 0 & 24 \\
\hline 107 & Iran & 2 & 0 & 0 & 0 & 0 & 0 & 0 & 2 \\
\hline 108 & Ireland & 179 & 0 & 0 & 0 & 0 & 0 & 0 & 179 \\
\hline 109 & Isle of Man & 3 & 0 & 0 & 0 & 0 & 0 & 0 & 3 \\
\hline 110 & Israel & 135 & 0 & 0 & 0 & 0 & 0 & 0 & 135 \\
\hline 111 & Jamaica & 16 & 0 & 0 & 0 & 0 & 0 & 0 & 16 \\
\hline 112 & Jersey & 2 & 0 & 0 & 0 & 0 & 0 & 0 & 2 \\
\hline 113 & Jordan & 6 & 0 & 0 & 0 & 0 & 0 & 0 & 6 \\
\hline 114 & Kyrgyzstan & 2 & 0 & 0 & 0 & 0 & 0 & 0 & 2 \\
\hline 115 & Laos & 2 & 0 & 0 & 0 & 0 & 0 & 0 & 2 \\
\hline 116 & Latvia & 14 & 0 & 0 & 0 & 0 & 0 & 0 & 14 \\
\hline 117 & Lebanon & 6 & 0 & 0 & 0 & 0 & 0 & 0 & 6 \\
\hline 118 & Libya & 6 & 0 & 0 & 0 & 0 & 0 & 0 & 6 \\
\hline 119 & Liechtenstein & 1 & 0 & 0 & 0 & 0 & 0 & 0 & 1 \\
\hline 120 & Luxembourg & 70 & 0 & 0 & 0 & 0 & 0 & 0 & 70 \\
\hline 121 & Macedonia & 2 & 0 & 0 & 0 & 0 & 0 & 0 & 2 \\
\hline 122 & Madagascar & 1 & 0 & 0 & 0 & 0 & 0 & 0 & 1 \\
\hline 123 & Malawi & 1 & 0 & 0 & 0 & 0 & 0 & 0 & 1 \\
\hline 124 & Malta & 4 & 0 & 0 & 0 & 0 & 0 & 0 & 4 \\
\hline 125 & Mauritania & 1 & 0 & 0 & 0 & 0 & 0 & 0 & 1 \\
\hline 126 & Mauritius & 2 & 0 & 0 & 0 & 0 & 0 & 0 & 2 \\
\hline 127 & Mexico & 141 & 0 & 0 & 0 & 0 & 0 & 0 & 141 \\
\hline
\end{tabular}




\begin{tabular}{|c|c|c|c|c|c|c|c|c|c|}
\hline \multirow{2}{*}{ Rank } & \multirow{2}{*}{ Acquirer's Nationality } & \multirow{2}{*}{$\begin{array}{l}\text { Non-SIEs } \\
\text { (Private } \\
\text { deals) }\end{array}$} & \multicolumn{6}{|c|}{ SIES } & \multirow{2}{*}{$\begin{array}{l}\text { Grand } \\
\text { Total }\end{array}$} \\
\hline & & & Air & Electricity & Mining & Oil \& Gas & Telecom & Total SIEs & \\
\hline 128 & Moldova & 4 & 0 & 0 & 0 & 0 & 0 & 0 & 4 \\
\hline 129 & Monaco & 1 & 0 & 0 & 0 & 0 & 0 & 0 & 1 \\
\hline 130 & Mongolia & 5 & 0 & 0 & 0 & 0 & 0 & 0 & 5 \\
\hline 131 & Mozambique & 1 & 0 & 0 & 0 & 0 & 0 & 0 & 1 \\
\hline 132 & Namibia & 4 & 0 & 0 & 0 & 0 & 0 & 0 & 4 \\
\hline 133 & Niger & 2 & 0 & 0 & 0 & 0 & 0 & 0 & 2 \\
\hline 134 & Nigeria & 43 & 0 & 0 & 0 & 0 & 0 & 0 & 43 \\
\hline 135 & Pakistan & 14 & 0 & 0 & 0 & 0 & 0 & 0 & 14 \\
\hline 136 & Palestinian Territo. & 1 & 0 & 0 & 0 & 0 & 0 & 0 & 1 \\
\hline 137 & Panama & 20 & 0 & 0 & 0 & 0 & 0 & 0 & 20 \\
\hline 138 & Papua New Guinea & 24 & 0 & 0 & 0 & 0 & 0 & 0 & 24 \\
\hline 139 & Paraguay & 2 & 0 & 0 & 0 & 0 & 0 & 0 & 2 \\
\hline 140 & Peru & 82 & 0 & 0 & 0 & 0 & 0 & 0 & 82 \\
\hline 141 & Philippines & 180 & 0 & 0 & 0 & 0 & 0 & 0 & 180 \\
\hline 142 & Puerto Rico & 3 & 0 & 0 & 0 & 0 & 0 & 0 & 3 \\
\hline 143 & Senegal & 1 & 0 & 0 & 0 & 0 & 0 & 0 & 1 \\
\hline 144 & Serbia & 7 & 0 & 0 & 0 & 0 & 0 & 0 & 7 \\
\hline 145 & Serbia and Montenegro & 4 & 0 & 0 & 0 & 0 & 0 & 0 & 4 \\
\hline 146 & Sierra Leone & 4 & 0 & 0 & 0 & 0 & 0 & 0 & 4 \\
\hline 147 & Slovak Republic & 16 & 0 & 0 & 0 & 0 & 0 & 0 & 16 \\
\hline 148 & Solomon Islands & 1 & 0 & 0 & 0 & 0 & 0 & 0 & 1 \\
\hline 149 & Sri Lanka & 9 & 0 & 0 & 0 & 0 & 0 & 0 & 9 \\
\hline 150 & Sudan & 3 & 0 & 0 & 0 & 0 & 0 & 0 & 3 \\
\hline 151 & Suriname & 2 & 0 & 0 & 0 & 0 & 0 & 0 & 2 \\
\hline 152 & Swaziland & 1 & 0 & 0 & 0 & 0 & 0 & 0 & 1 \\
\hline 153 & Tanzania & 7 & 0 & 0 & 0 & 0 & 0 & 0 & 7 \\
\hline 154 & Trinidad and Tobago & 3 & 0 & 0 & 0 & 0 & 0 & 0 & 3 \\
\hline 155 & Tunisia & 6 & 0 & 0 & 0 & 0 & 0 & 0 & 6 \\
\hline 156 & Turks and Caicos Is. & 1 & 0 & 0 & 0 & 0 & 0 & 0 & 1 \\
\hline 157 & Uganda & 4 & 0 & 0 & 0 & 0 & 0 & 0 & 4 \\
\hline 158 & Ukraine & 89 & 0 & 0 & 0 & 0 & 0 & 0 & 89 \\
\hline 159 & Uruguay & 2 & 0 & 0 & 0 & 0 & 0 & 0 & 2 \\
\hline 160 & Uzbekistan & 5 & 0 & 0 & 0 & 0 & 0 & 0 & 5 \\
\hline 161 & Vanuatu & 1 & 0 & 0 & 0 & 0 & 0 & 0 & 1 \\
\hline 162 & Virgin Islands & 12 & 0 & 0 & 0 & 0 & 0 & 0 & 12 \\
\hline 163 & Virgin Islands (U.S.) & 11 & 0 & 0 & 0 & 0 & 0 & 0 & 11 \\
\hline 164 & Zambia & 4 & 0 & 0 & 0 & 0 & 0 & 0 & 4 \\
\hline 165 & Zimbabwe & 11 & 0 & 0 & 0 & 0 & 0 & 0 & 11 \\
\hline & Total & 41,062 & 188 & 1,030 & 885 & 1,739 & 1,141 & 4983 & 46,045 \\
\hline
\end{tabular}


Table A4. SIEs international deals, by acquirer nationality (1998-2012)

\begin{tabular}{|c|c|c|c|c|}
\hline Rank & Acquirer Nationality & Freq. & Percent & Cumulative \\
\hline 1 & France & 325 & 14.12 & 14.12 \\
\hline 2 & China & 300 & 13.04 & 27.16 \\
\hline 3 & Norway & 164 & 7.13 & 34.29 \\
\hline 4 & Italy & 144 & 6.26 & 40.55 \\
\hline 5 & Russian Federation & 137 & 5.95 & 46.5 \\
\hline 6 & Germany & 103 & 4.48 & 50.98 \\
\hline 7 & Brazil & 94 & 4.09 & 55.06 \\
\hline 8 & Austria & 89 & 3.87 & 58.93 \\
\hline 9 & Japan & 71 & 3.09 & 62.02 \\
\hline 10 & Finland & 65 & 2.82 & 64.84 \\
\hline 11 & India & 63 & 2.74 & 67.58 \\
\hline 12 & Sweden & 63 & 2.74 & 70.32 \\
\hline 13 & Singapore & 53 & 2.3 & 72.62 \\
\hline 14 & United Arab Emirates & 51 & 2.22 & 74.84 \\
\hline 15 & South Korea & 47 & 2.04 & 76.88 \\
\hline 16 & Malaysia & 45 & 1.96 & 78.84 \\
\hline 17 & Hungary & 41 & 1.78 & 80.62 \\
\hline 18 & Colombia & 40 & 1.74 & 82.36 \\
\hline 19 & Denmark & 35 & 1.52 & 83.88 \\
\hline 20 & Switzerland & 34 & 1.48 & 85.35 \\
\hline 21 & Poland & 29 & 1.26 & 86.61 \\
\hline 22 & Czech Republic & 25 & 1.09 & 87.7 \\
\hline 23 & Venezuela & 22 & 0.96 & 88.66 \\
\hline 24 & Belgium & 21 & 0.91 & 89.57 \\
\hline 25 & Qatar & 21 & 0.91 & 90.48 \\
\hline 26 & Kuwait & 20 & 0.87 & 91.35 \\
\hline 27 & Slovenia & 19 & 0.83 & 92.18 \\
\hline 28 & Hong Kong, China & 18 & 0.78 & 92.96 \\
\hline 29 & Greece & 17 & 0.74 & 93.7 \\
\hline 30 & Indonesia & 17 & 0.74 & 94.44 \\
\hline 31 & Azerbaijan & 15 & 0.65 & 95.09 \\
\hline 32 & Oman & 15 & 0.65 & 95.74 \\
\hline 33 & Thailand & 10 & 0.43 & 96.18 \\
\hline 34 & Algeria & 8 & 0.35 & 96.52 \\
\hline 35 & Kazakhstan & 8 & 0.35 & 96.87 \\
\hline 36 & Lithuania & 6 & 0.26 & 97.13 \\
\hline 37 & Morocco & 6 & 0.26 & 97.39 \\
\hline 38 & New Zealand & 6 & 0.26 & 97.65 \\
\hline 39 & United Kingdom & 6 & 0.26 & 97.91 \\
\hline 40 & Saudi Arabia & 5 & 0.22 & 98.13 \\
\hline 41 & South Africa & 5 & 0.22 & 98.35 \\
\hline 42 & Spain & 5 & 0.22 & 98.57 \\
\hline 43 & Chinese Taipei & 5 & 0.22 & 98.78 \\
\hline 44 & Turkey & 5 & 0.22 & 99 \\
\hline 45 & Vietnam & 4 & 0.17 & 99.17 \\
\hline 46 & Chile & 3 & 0.13 & 99.3 \\
\hline 47 & Kenya & 3 & 0.13 & 99.44 \\
\hline 48 & Australia & 2 & 0.09 & 99.52 \\
\hline 49 & Egypt & 2 & 0.09 & 99.61 \\
\hline
\end{tabular}




\begin{tabular}{lllll}
50 & Netherlands & 2 & 0.09 & 99.7 \\
51 & Angola & 1 & 0.04 & 99.74 \\
52 & Argentina & 1 & 0.04 & 99.78 \\
53 & Canada & 1 & 0.04 & 99.83 \\
54 & New Caledonia & 1 & 0.04 & 99.87 \\
55 & Portugal & 1 & 0.04 & 99.91 \\
56 & Romania & 1 & 0.04 & 99.96 \\
57 & United States & 1 & 0.04 & 100 \\
\hline
\end{tabular}

Source: Dealogic 